\title{
RESURRECTING THE RUINS
}

FRANCES BASOBAS 



\title{
Resurrecting the Ruins
}

\author{
By
}

Frances Basobas

A 120-point thesis submitted to the

Victoria University of Wellington in partial fulfilment of the requirements for the degree of Master of Architecture (Professional)

Victoria University of Wellington

School of Architecture 


\section{ACKNOWLEDGEMENTS}

there are so many people that i hold so dear to my heart:

from old friends from the beginning of this journey

to new friends that i made along the way.

but most importantly,

my family: my mom, my dad, and my brother.

everything i am and everything i've done, your love and support helped me get to where i am today.

thank you. 
Construction and Demolition (C\&D) waste contributes to over 50\% of New Zealand's overall waste. Materials such as timber, plasterboard, and concrete make up $81 \%$ of the C\&D waste that goes into landfills each year. Alongside this, more than 235 heritage-listed buildings have been demolished in Christchurch since the 2011 earthquakes. This research portfolio aims to find a solution to decrease C\&D waste produced by demolishing heritage buildings.

With the recent announcement of The Cathedral of the Blessed Sacrament's demolition, this will be another building added to the list of lost heritage in Christchurch. This research portfolio aims to bridge the relationship between heritage and waste through the recycling and reuse of the demolished materials, exploring the idea that history and heritage are preserved through building material reuse.
This research portfolio mainly focuses on reducing construction and demolition waste in New Zealand, using the design of a new Catholic Cathedral as a vessel. This thesis will challenge how the construction and design industry deals with the demolition of heritage buildings and their contribution to New Zealand's waste. It aims to explore the idea of building material reuse not only to reduce waste but also to retain the history and heritage of the demolished building within the materials 


\section{CONTENTS}

Acknowledgements

Abstract

INTRODUCTION

1.1 Aims and Objectives

1.2 Methodology

1.3 Design Scope

CHRISTCHURCH 2011 AND HISTORY OF THE CATHEDRAL

2.1 Christchurch 2011 Earthquake

2.2 Cathedral of the Blessed Sacrament

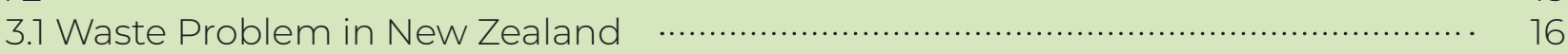

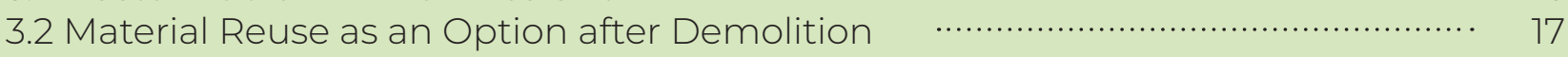

3.3 Potential Benefits of Material Reuse ............................................................... 18

3.3.1 Environmental Benefits

3.3.2 Financial Benefits

3.3.3 Social Benefits

3.4 Factors to Consider for Material Reuse

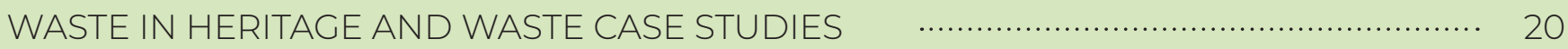

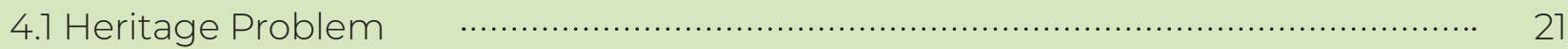

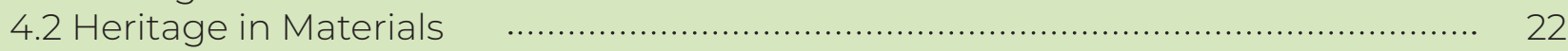

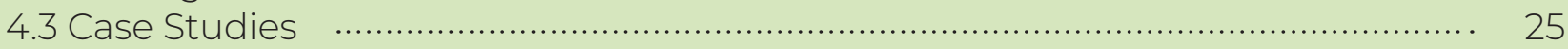

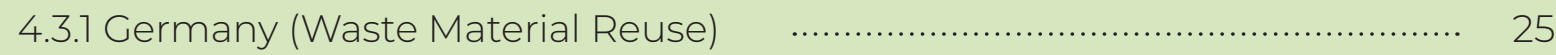

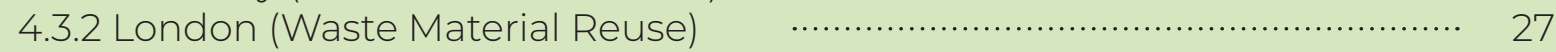

4.3.3 Zurich (Waste Material Reuse) $\quad$ …................................................ 29

4.3.4 Ankara, Turkey (Heritage Material Reuse) $\quad$ …................................... 30

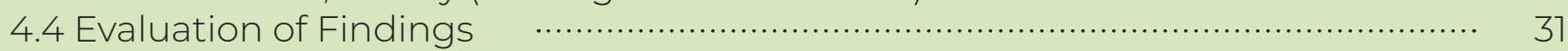

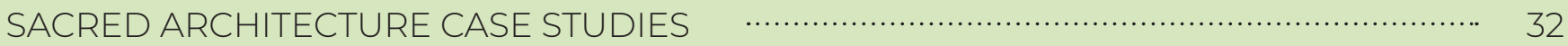

5.1 Case Studies

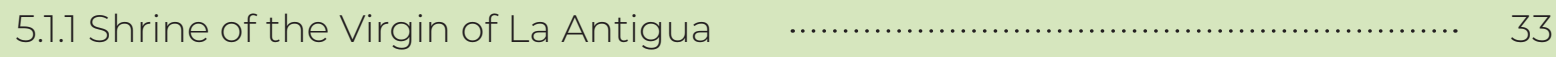

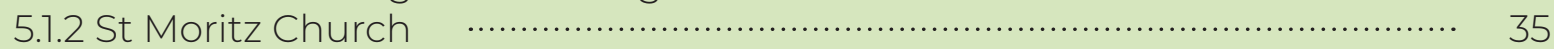

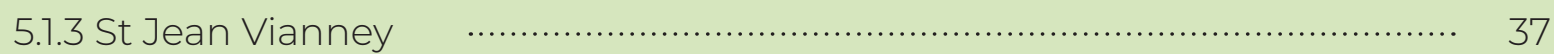

SITE ANALYSIS

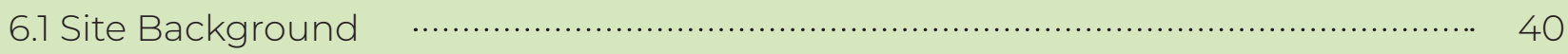

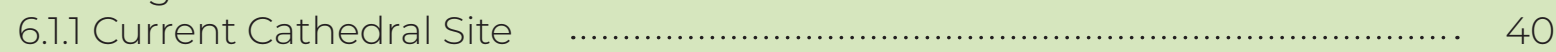

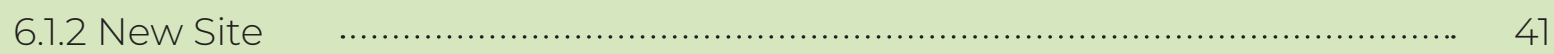

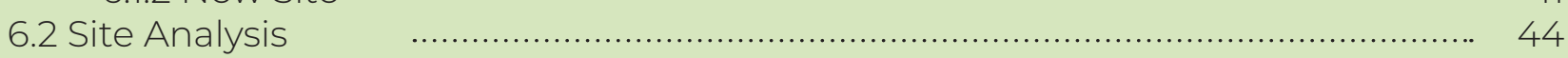

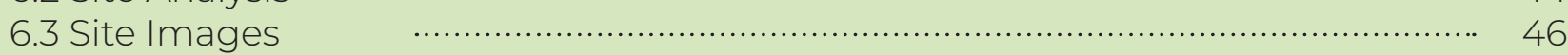

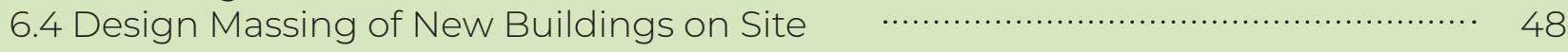




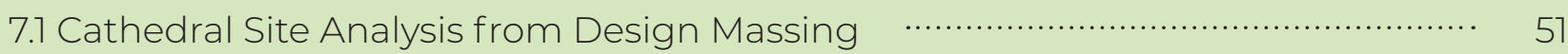

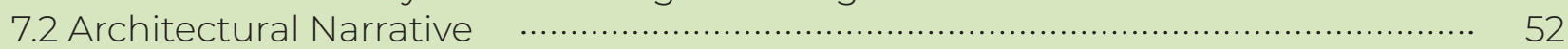

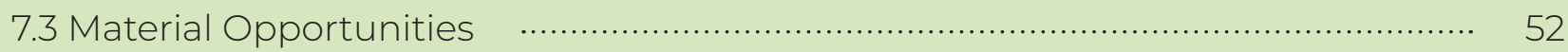

7.3.1 Copper Dome

7.3.2 Limestone

7.3.3 Concrete

7.3.4 Kauri Timber Roof Structure

7.3.5 Pressed Zinc Sheets

7.3.6 Ionic Columns

CONCEPT DESIGN

54

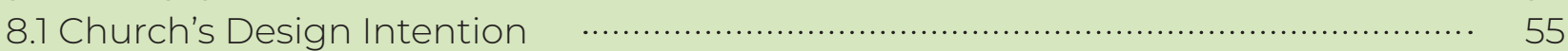

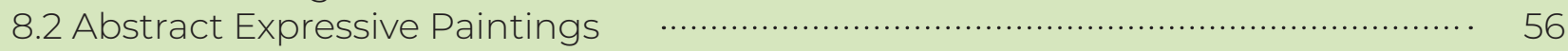

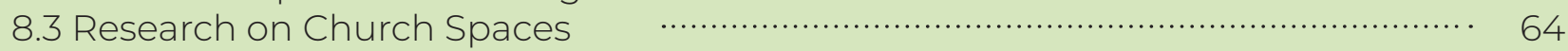

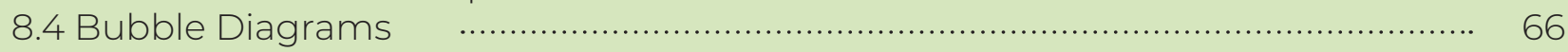

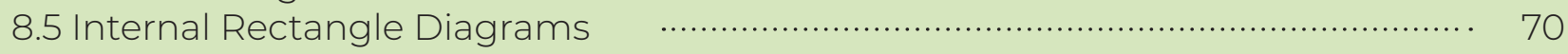

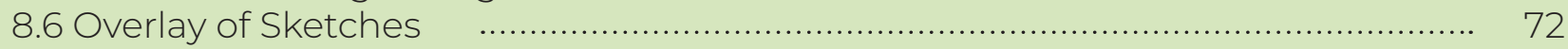

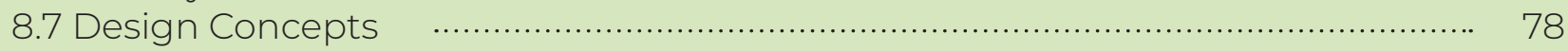

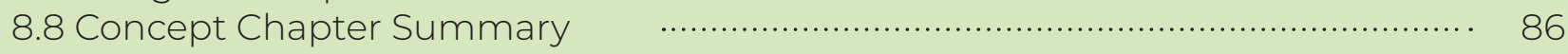

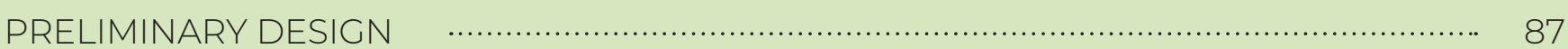

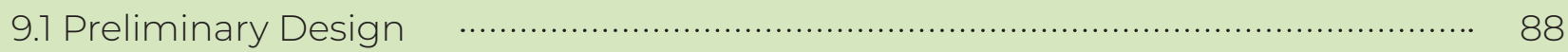

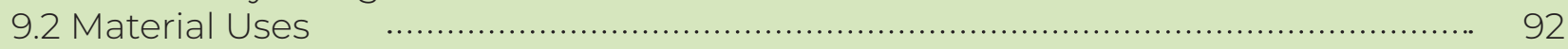

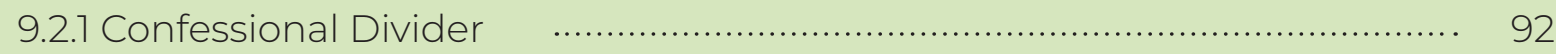

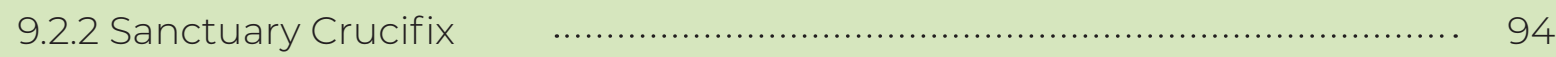

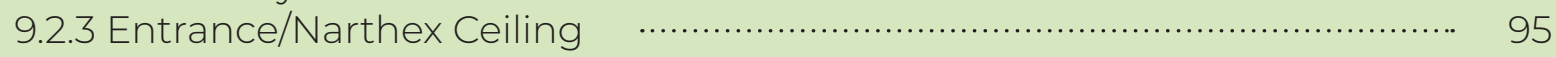

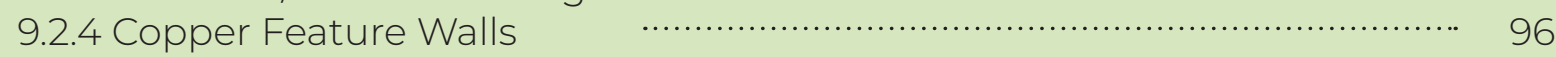

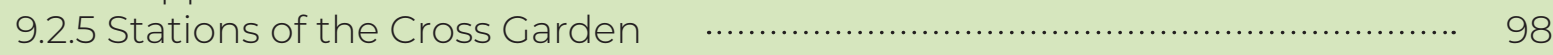

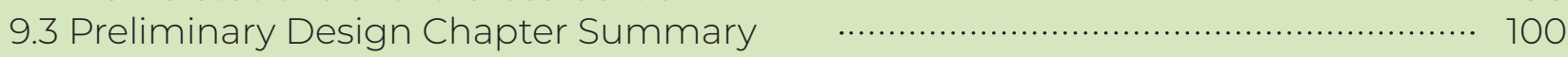

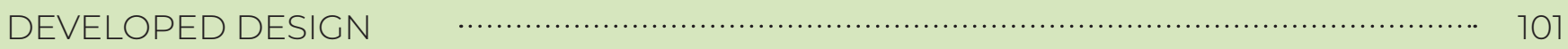

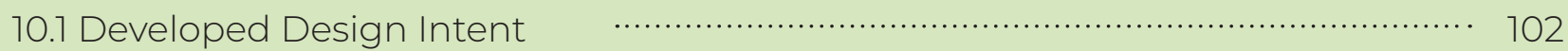

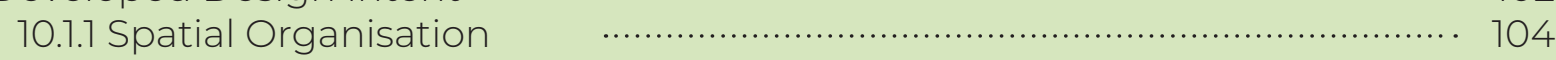

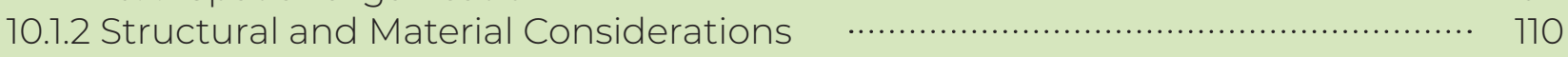

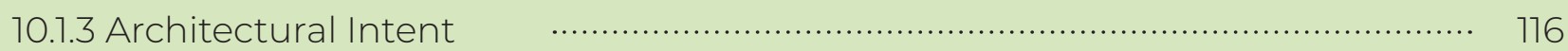

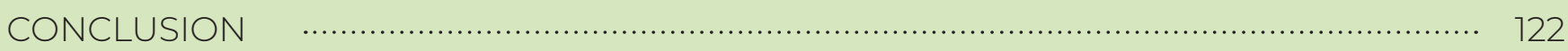

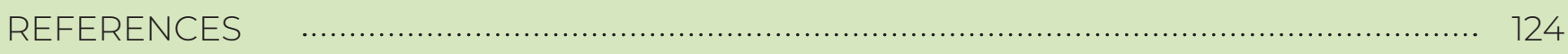

LIST OF FIGURES 

CHAPTER 1

INTRODUCTION 


\subsection{AIMS AND OBJECTIVES}

\section{Research Question:}

What is the viability of decreasing construction and demolition waste and preserving heritage value in heritage buildings by material reuse?

This research portfolio aims to produce a design, following proper church design through research, for a new cathedral for the catholic community in Christchurch as they currently do not have one. The proposed design will be made from reusing the demolished materials of the Cathedral of the Blessed Sacrament. Through material reuse, the design aims to retain pieces of history and heritage within the new Cathedral materials so that not all heritage is lost in the Catholic Basilica demolition. This thesis's primary aim is to develop a design that wholly solves all the problems regarding waste minimisation, heritage preservation, and sacred architecture into one building.
This can be achieved through:

1. Research on material reuse and its relationship with both waste and heritage

2. Research on sacred architecture and understanding what makes a successful church

3. Design experimentation and development based on earlier findings

This research portfolio's main objective is to identify the most significant contributors to waste in the New Zealand construction industry and identify the factors needed in the process of material reuse. This is important so that the proposed design and the process it went through for material reuse can be a solution or an option for future heritage buildings to be demolished so that waste from demolition can be decreased. 


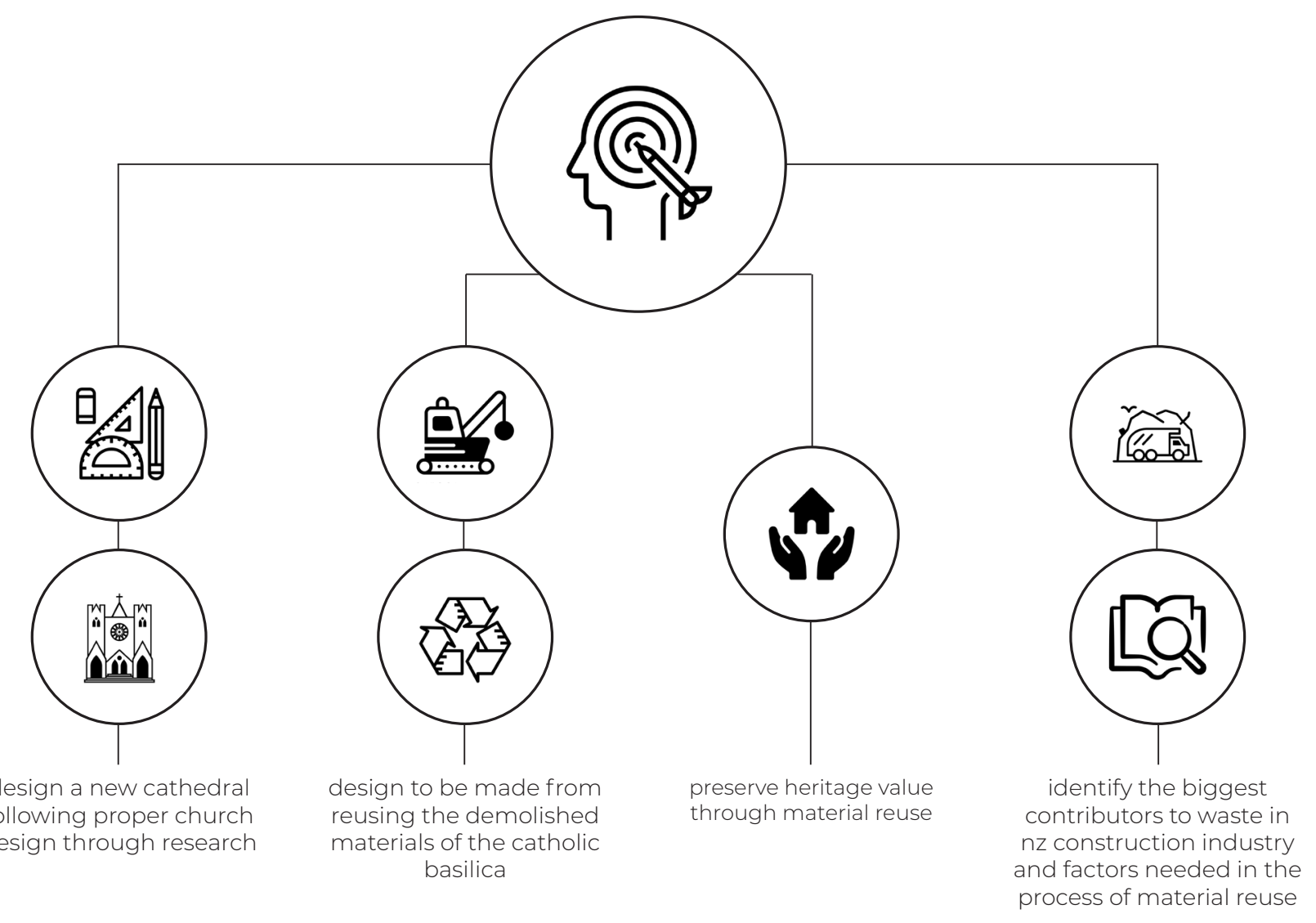

fig1.01 diagram of thesis aims and objectives 


\subsection{METHODOLOGY}

The process behind this research portfolio is conducted into two different research sections. The first part of the research is focused on identifying the problem regarding high waste in New Zealand and the lack of innovative heritage preservation methods. Following this, research is done on material reuse as it is identified as the possible solution to the waste and heritage problem recognised. Analysis of where heritage lies is also done to discover if material reuse is a viable option for heritage preservation. Alongside this, case studies of successful material reuse projects to minimise waste and preserve heritage are also explored. Part one of the research is concluded by findings of whether or not material reuse is the possible solution for the research problem.

The second part of this thesis is solely focused on sacred architecture and has a similar structure. Where a problem of needing a new Cathedral is identified, research on sacred architecture is done to determine how to design appropriately to solve this problem. Following this, experimentation, preliminary design, and design development are conducted to produce a new Cathedral design that responds to both the brief and the site provided.
While these two research sections are done separately, they do merge in the design stage. The design stage explores how the materials of the Cathedral of the Blessed Sacrament can be reused to preserve heritage value using the findings of material reuse from part one of the research. Once the reusable materials are determined, putting these materials into a new design of a cathedral using the findings of church architecture and how they operate from part two of the research is performed. 


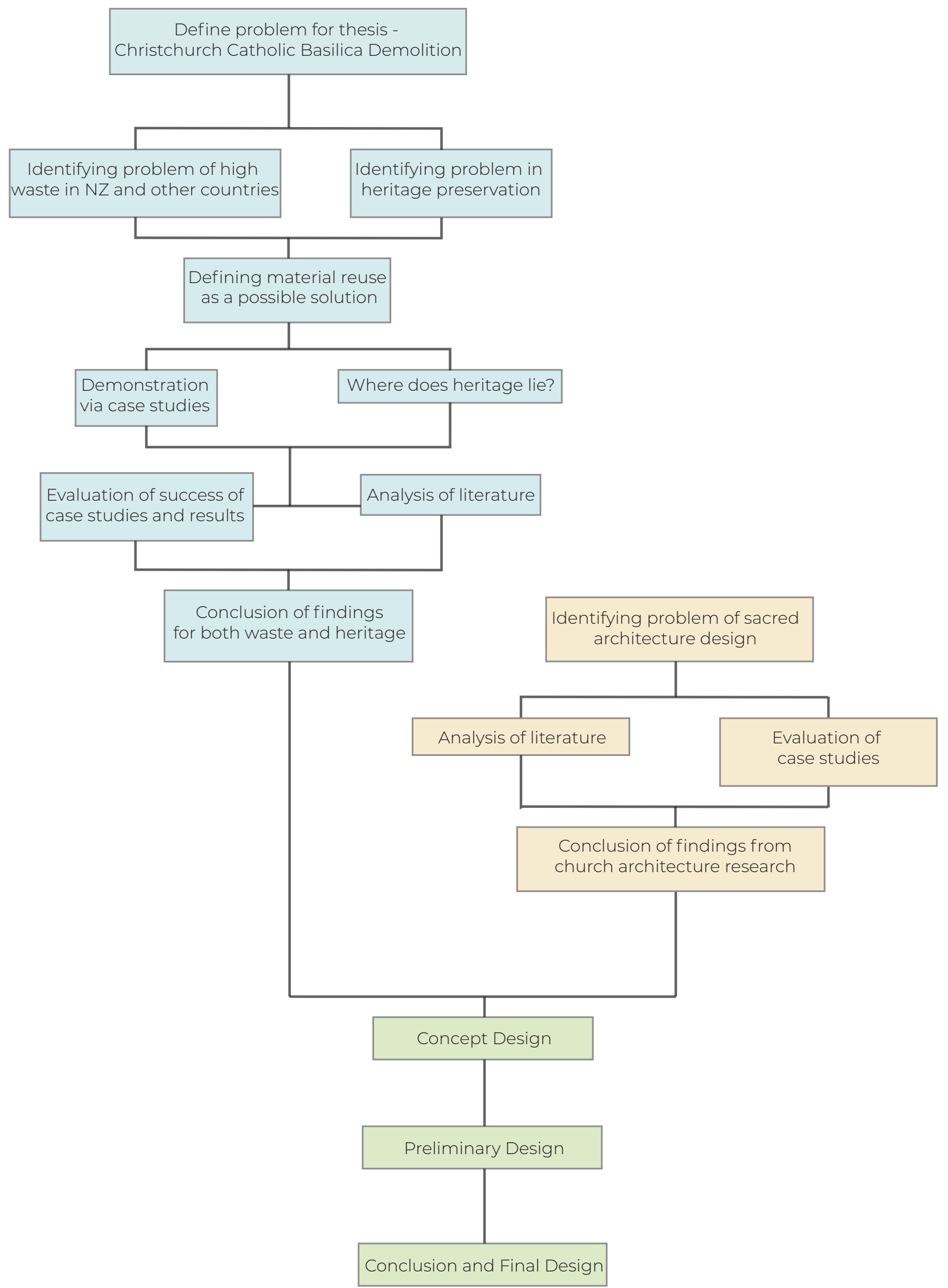

fig1.02 methodology diagram 


\subsection{DESIGN SCOPE}

This design research is focused on material reuse and how that fits into heritage preservation and sacred architecture. The Cathedral of the Blessed Sacrament will be used as a vessel in this research and will be the primary source of reused materials. The new design will take part in a completely new site that the Christchurch Diocese has purchased for their new Cathedral plans. This research portfolio will consider the different stages and aspects of design and research to produce a new Cathedral design using old materials and following sacred architecture methods. 


\section{CHAPTER 2}

\section{CHRISTCHURCH 2011 \\ AND HISTORY OF THE CATHEDRAL}




\subsection{CHRISTCHURCH 2011 \\ EARTHQUAKE}

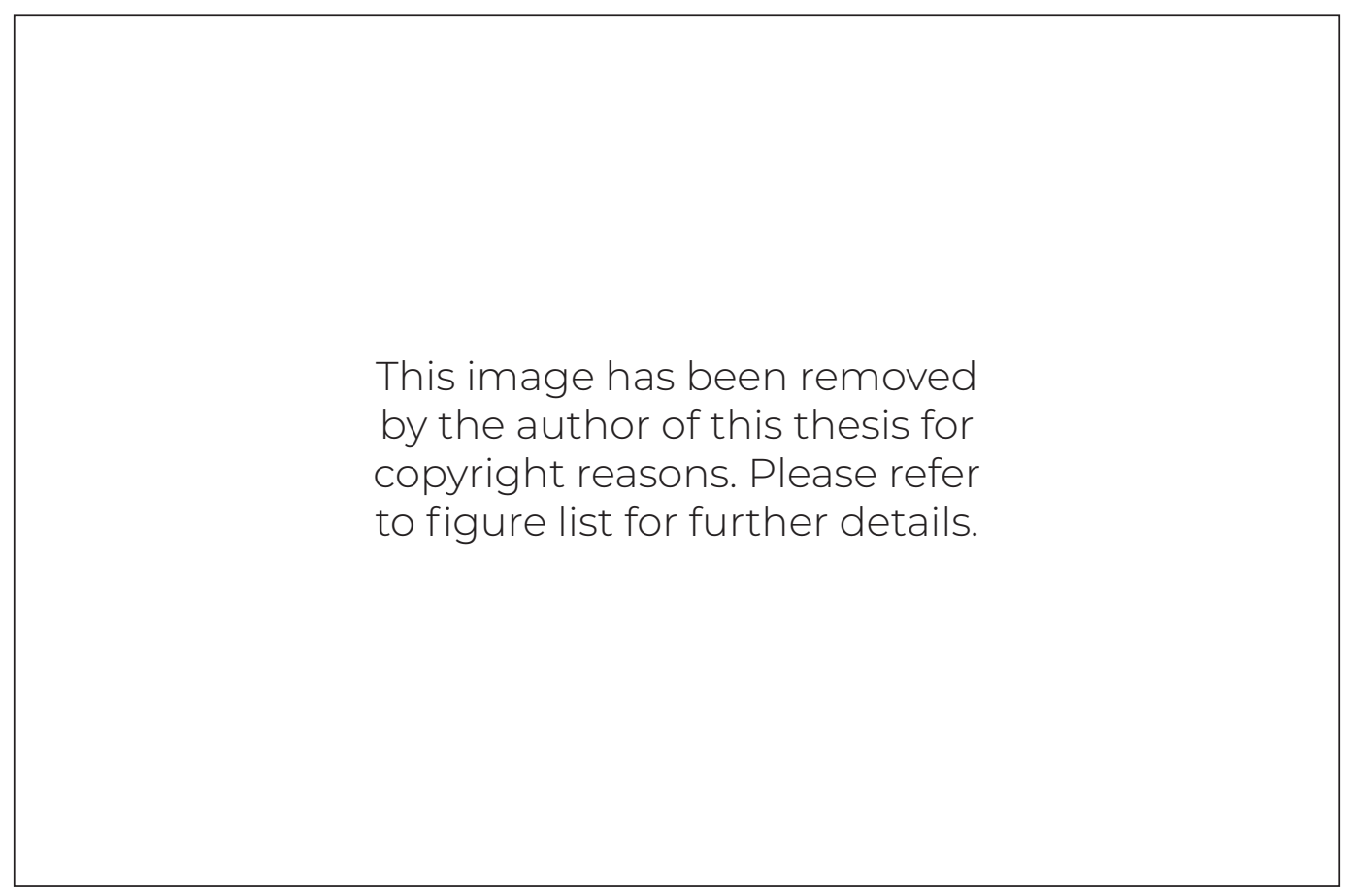

fig2.01 cathedral of the blessed sacrament destruction after 2011 christchurch earthquake

A magnitude 6.3 earthquake struck at 12:51 pm on Tuesday, 22 February 2011 and caused severe damage in Christchurch and Lyttelton (Ministry for Culture and Heritage, 2020). This devastating earthquake killed 185 people and injured several thousand (Ministry for Culture and Heritage, 2020). Although not as powerful as the magnitude 7.1 earthquake that occurred six months earlier on 4 September 2010, the February earthquake was destructive as it occurred on a shallow fault line close to the city (Ministry for Culture and Heritage, 2020).
Many of the damaged and unstable buildings left in September, mainly the older brick and mortar buildings, were brought down by the Christchurch February 2011 Earthquake (Ministry for Culture and Heritage, 2020). The devastating earthquake left the city in ruins. As a result, more than half of the central business district buildings had no other option but to be demolished (Ministry for Culture and Heritage, 2020). Many of the city's heritage buildings were heavily affected and suffered severe damage, such as the Provincial Council Chambers, Lyttelton's Timeball Station, the Anglican Christchurch Cathedral, and the Catholic Cathedral of the Blessed Sacrament (Ministry for Culture and Heritage, 2020). 


\subsection{CATHEDRAL OF THE BLESSED SACRAMENT}

Most buildings leave a lasting impression on their visitors. In some cases, the cause might be a deep personal association. It could be the emotions that arise when inside the space or even be the architecture provoking the feelings of spirituality. Feelings and impressions can be enhanced and influenced by many things such as the building's scale, the grandeur of its architecture, its beautiful decorations and furnishings, its purpose, or even its history (Hanrahan, 2004, p. 5). Many visitors speak of the lasting impressions they leave with after they experience the beauty of the Cathedral of the Blessed Sacrament. Feelings and emotions that should be evoked in a sacred space are achieved in this building (Hanrahan, 2004, p. 5).

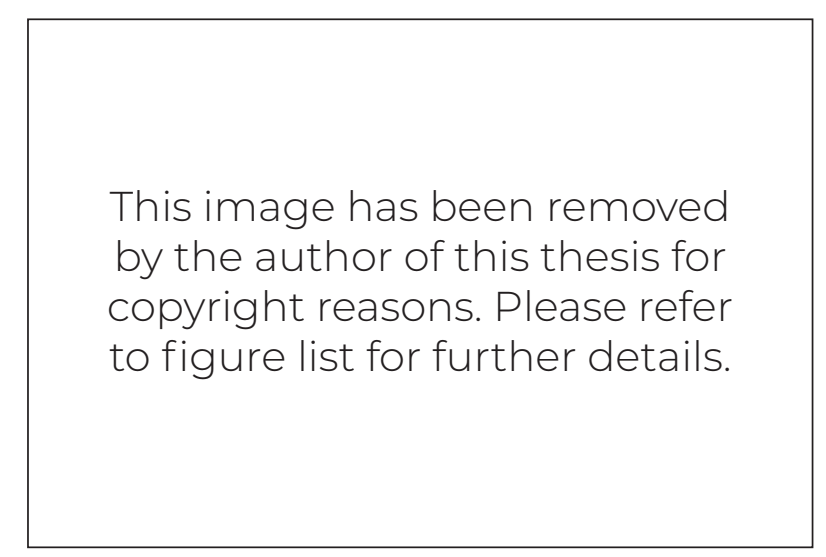

fig2.02 cathedral of the blessed sacrament
The history of the Cathedral of the Blessed Sacrament building goes all the way back to the end of January 1899, when Bishop Grimes, the first Catholic Bishop of Christchurch, had started planning for the Cathedral he envisioned for Christchurch (Hanrahan, 2004, p. 25). Grimes' first plan of action was to appoint an architect, settle on a design, and find a suitable site for this grand building that he was planning (Hanrahan, 2004, p. 25).

Dunedin architect Francis Petre was chosen to carry on the Cathedral project as Grimes was familiar with his work (Hanrahan, 2004, p. 25). Grimes spent much of January 1899 in Wellington to attend to Church matters. He appears to have met Petre and become familiar with his work during his stay as Wellington's Sacred Heart Basilica (now Cathedral) was currently being built on Hill Street, with Petre as its lead architect (Hanrahan, 2004, p. 25).

This image has been removed by the author of this thesis for copyright reasons. Please refer to figure list for further details.

fig2.03 wellington sacred heart cathedral 
Grimes later said that it was suggested that the Christchurch Cathedral design be made a competition between architects. Ultimately, he was impressed by the beautiful plans and sketches that Petre submitted. Because Grimes wanted to get started with construction as soon as possible, Petre's design was accepted with the committee's approval (Hanrahan, 2004, p. 25). In Petre's design, it was clear that he favoured a basilica and felt he had to urge strongly against a gothic design for the Cathedral (Hanrahan, 2004, p. 27). Petre's argument for this design choice was that the idea of gothic must be given up and instead to take up the Roman Basilica as a model if size, dignity, and permanency at a minimum cost are what Grimes wanted for his Cathedral (Hanrahan, 2004, p. 27).

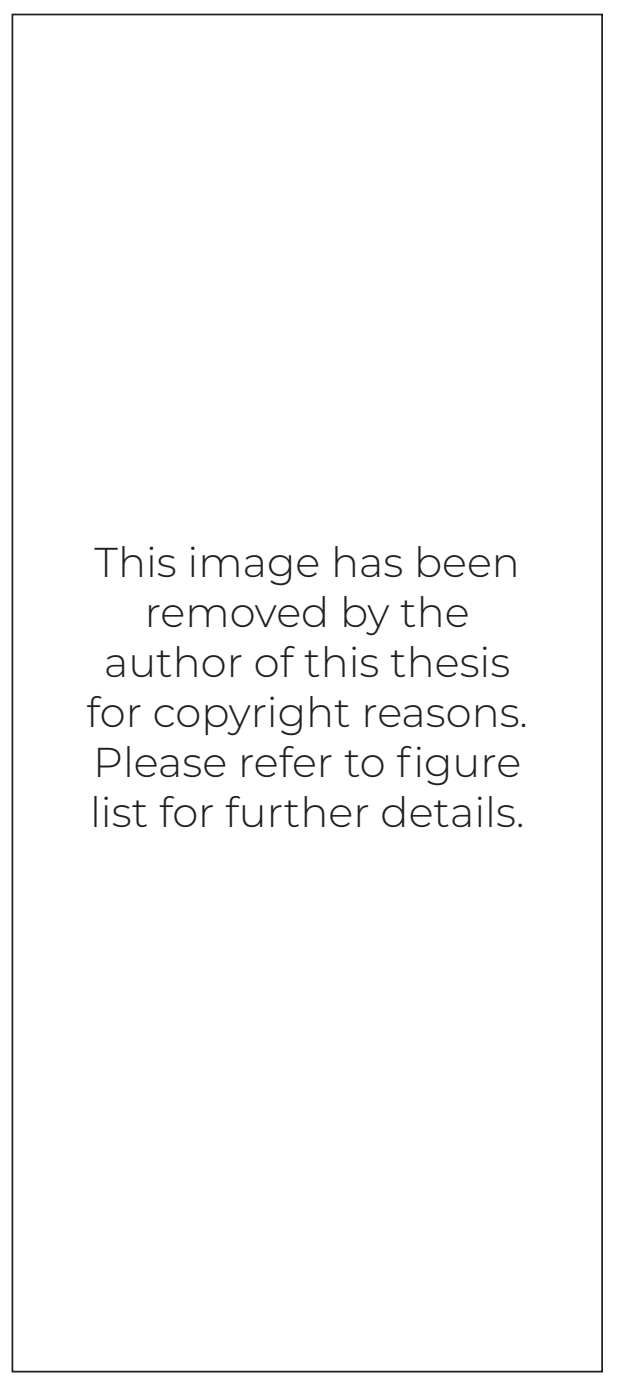

Multiple obstacles faced over the months after Petre was assigned the job, such as not securing contractors due to costs and Petre's complicated design plans. This resulted in Grimesabandoning the tenders received in July 1900, and fresh tenders had been invited based on amended plans and specification (Hanrahan, 2004, p. 38). The Jamieson Brothers, James and William, of Christchurch responded, secured the contract, and slowly but surely, construction of the Cathedral of the Blessed Sacrament finally started and continued over the next couple of years (Hanrahan, 2004, p. 39). Massproduced components were widely used during construction, such as the curved arches made in a purpose-built moulding machine (Hanrahan, 2004, p. 39). Over fifty men were employed on the site to help with construction, and around $3400 \mathrm{~m} 3$ of Oamaru stone, $560 \mathrm{~m} 3$ of Mount Somers stone, $110 \mathrm{~m} 3$ of concrete, and about 90 tons of steel were used to construct the Cathedral (Hanrahan, 2004, p. 42). With the Cathedral nearing completion, Bishop Grimes set February 12, 1905, as the Cathedral's opening and dedication, despite having no set possession date from the builders (Hanrahan, 2004, p. 56).

Once open to the public, the Catholic Basilica became a significant building in the area and the community. Not only did the Cathedral come to be accepted and loved as a parish church, but it was also the mother church of the Christchurch Diocese and was also a place for grand processions and solemn ceremonies just as Grimes had planned years before (Hanrahan, 2004, p. 74). 
This image has been removed by the author of this thesis for copyright reasons. Please refer to figure list for further details.

fig2.05 the walls were finished with mount somers stone to windowsill height and oamaru stone above that point

\author{
fig2.06 interior view of cathedral during \\ construction \\ fig2.07 plan of cathedral as it was originally \\ proposed by francis petre

This image has been removed by the author of this thesis for copyright reasons. Please refer to figure list for further details.

This image has been removed by the author of this thesis for copyright reasons. Please refer to figure list for further details. 


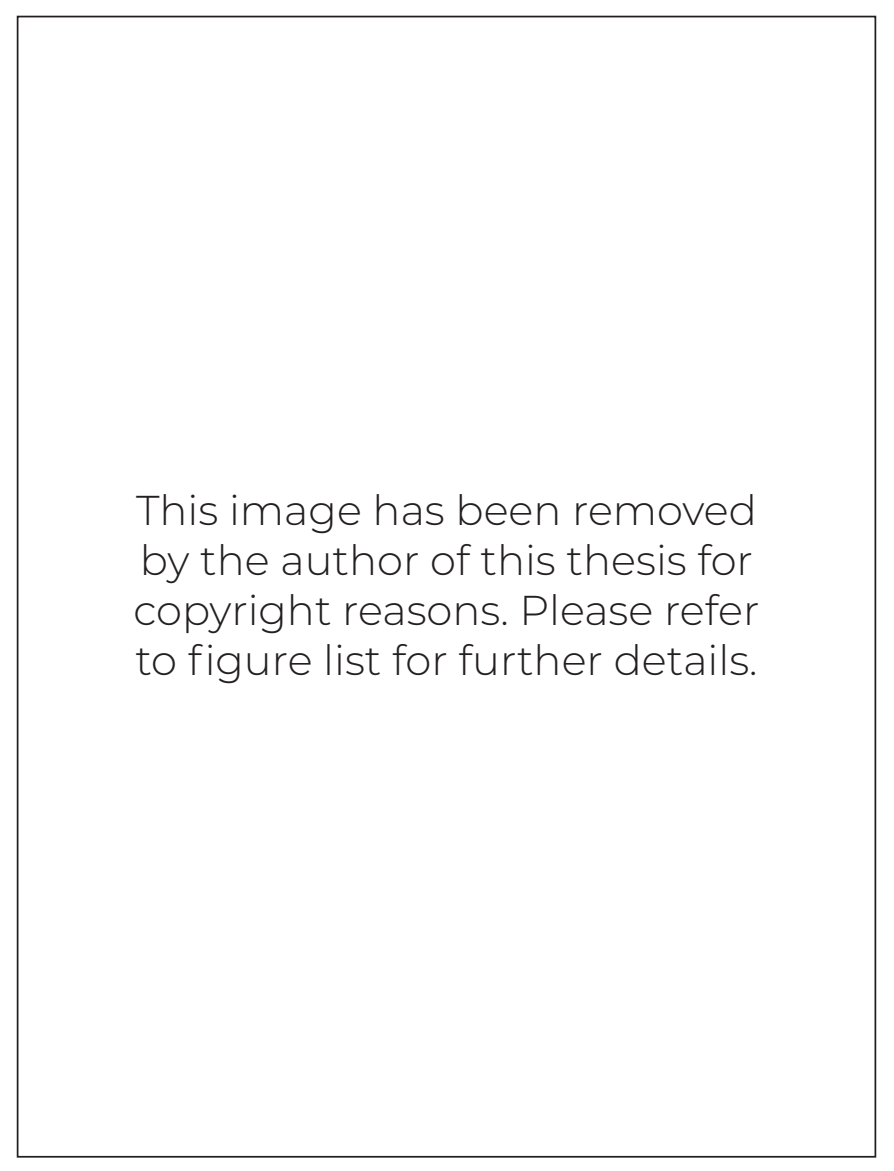

fig2.08 holy souls chapel, bishop grimes' final resting place

Hours before his death on 15 March 1915, Bishop Grimes had expressed his wish to be buried in his Cathedral, and a vault was then prepared in the floor of the Holy Souls Chapel (Hanrahan, 2004, p. 75). Grimes' coffin was then later carried to its resting place at the foot of the Holy Souls altar (Hanrahan, 2004, p. 75). Today, two other bishops, Joyce and Cunneen, are also buried under the Cathedral as per their request.

Francis Petre's death followed less than four years after Bishop Grimes, dying in Dunedin on 10 December 1918 (Hanrahan, 2004, p. 76). Petre left behind beautiful architectural works, including several basilicas, such as those in Wellington, Timaru, Oamaru, Waimate, South Dunedin, and Invercargill (Hanrahan, 2004, p. 76). However, none exceed his neoclassical masterpiece in Christchurch, the Cathedral of the Blessed Sacrament (Hanrahan, 2004, p. 77).
The Cathedral of the Blessed Sacrament is an architectural masterpiece as Petre's use of space, both vertical and horizontal within the building, is almost wasteful. However, it is bold, imaginative, and extravagant (Hanrahan, 2004, p. 77). The repetitive colonnades that Petre used to march the length of the building and replicating them at higher levels and again on the porticos is another successful feature of Petre's work (Hanrahan, 2004, p. 77). Even though Petre's treatment of the dome is a successful interior feature, moving it from the usual position over the crossing of the nave and transept to above the sanctuary, the dome does not work successfully from the exterior (Hanrahan, 2004, p. 77). The dome's placement has resulted in appearing narrow for its height as moving it from behind the gables of the transept has added to its visible vertical dimension (Hanrahan, 2004, p. 77). 
This image has been removed by the author of this thesis for copyright reasons. Please refer to figure list for further details.

fig2.09 interior view of the nave, showing the repetitive colonnades used throughout the building as an architectural feature 
After the Second Vatican Council in 1965 addressed the relations between the Catholic Church and the modern world, modifications were needed to bring the Cathedral up to date with Vatican Il's decrees (Hanrahan, 2004, p. 90). As Vatican II brought massive change to the church's order and how it operated, many were opposed to the modifications and resisted change as they had grown to love the building as it was (Hanrahan, 2004, p. 90). Changing the altar, constructing a new Blessed Sacrament Side Chapel, removal of altar rails, a new Bishop's chair, and converting the pulpit into a lectern were some of the matters that were proposed to Bishop Ashby that were brought on by Vatican II (Hanrahan, 2004 , p. 90). Renovation and repair of the interior fabric were high on the list, as were adding heating and toilet facilities in the Cathedral, moving the baptistery and confessionals to a more private area of the building, and also rebuilding the organ and replacing the Stations of the Cross (Hanrahan, 2004, p. 90). Bishop Ashby wrote if the Christchurch-based architectural firm, Warren and Mahoney, were interested in updating the Cathedral and received a reply from Miles Warren accepting the job (Hanrahan, 2004, p. 90).
Warren's first move was to comment in detail on the liturgical sub-committees extensive brief that was prepared for him. He then made and cost many of the suggestions, such as painting the dado and the plastered ceilings of the side aisles, tiling the floor, and extending the raised sanctuary into the side aisles (Hanrahan, 2004, p. 90). With some of these changes in mind, Warren prepared modification plans for the Cathedral that he felt met not only the needs of post-Vatican II but also achieved "Francis Petre's vision of an uncluttered building with an emphasis on its neoclassical lines" (Hanrahan, 2004, p. 90).

Due to the building's extensive history, architectural contribution, and association with renowned architect Francis Petre, the Cathedral of the Blessed Sacrament is a Category I Heritage-Listed Building by Heritage New Zealand (Heritage New Zealand Pouhere Taonga, 2021).

This image has been removed by the author of this thesis for copyright reasons. Please refer to figure list for further details. 


\section{CHAPTER 3}

WASTE 


\subsection{WASTE PROBLEM IN NEW ZEALAND}

New Zealand has a waste problem where C\&D waste is one of the country's most significant waste streams (BRANZ, 2020). The construction industry contributes to C\&D waste that totals to over $50 \%$ of New Zealand's overall waste (Ministry for the Environment, 2007). This waste breaks down to approximately 850,000 tonnes of C\&D materials going into the landfill and around 1.3 million tonnes going into the cleanfill (Ministry for the Environment, 2007). Three building materials contribute to approximately $81 \%$ of C\&D waste in New Zealand -timber and wood fibre with 38\%, plasterboard with 18\%, and concrete with 25\% (Ministry for the Environment, 2007). Disposing large numbers of these C\&D materials to the landfills suggests that they are not being recovered for further use (BRANZ, 2020). This suggests that these materials contribute harmful effects to the environment, like chemicals leaching into the soil and waterways and create methane emissions as the material waste breaks down and rots over time (BRANZ, 2020). Much of the C\&D waste produced by the construction industry can be reduced, reused, and recovered, which then allows the large numbers of C\&D waste going into the landfills to be dramatically decreased (BRANZ, 2020).

fig3.01 material breakdown of construction and demolition waste in new zealand

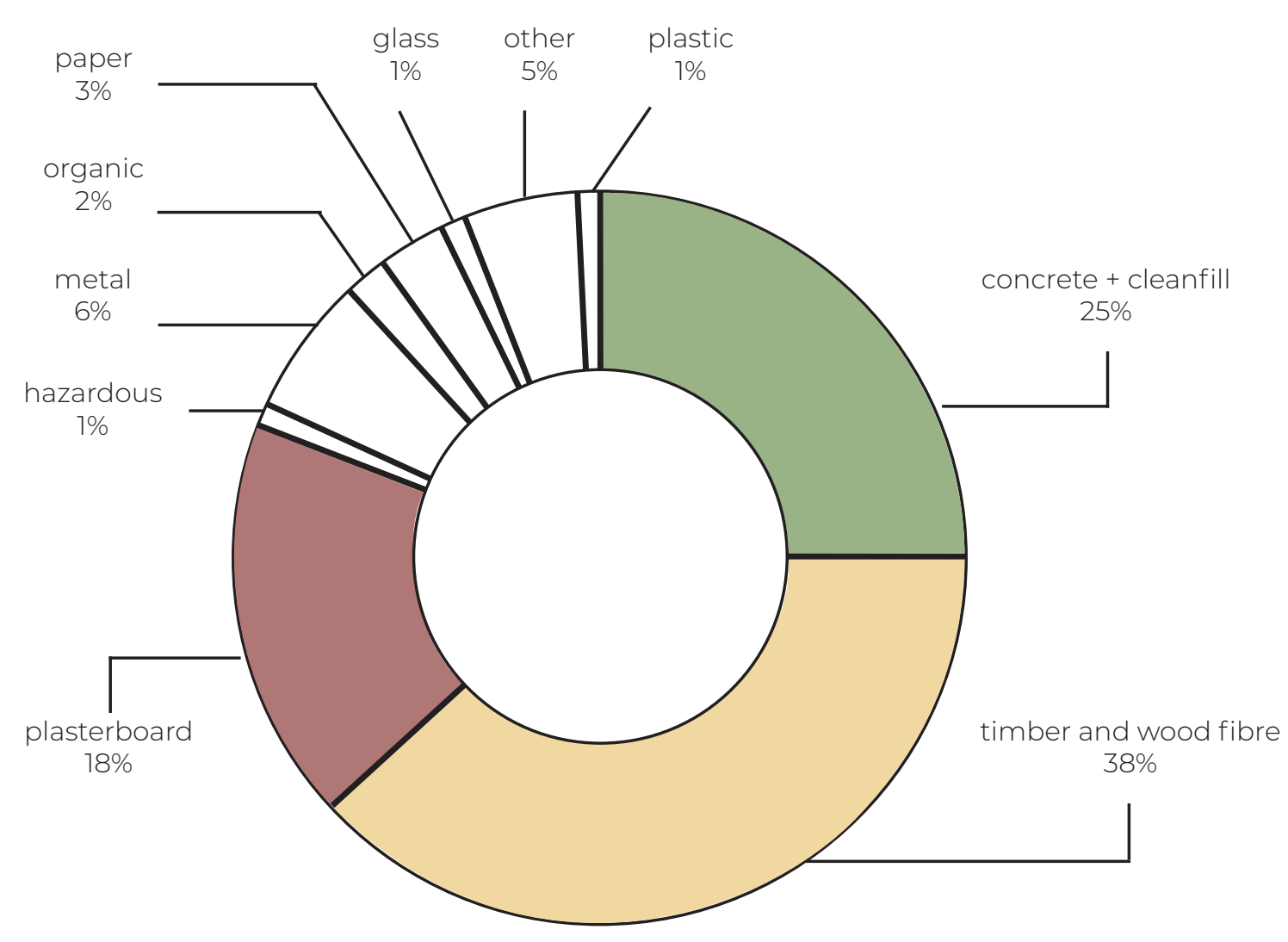




\subsection{MATERIAL REUSE AS AND OPTION AFTER DEMOLITION}

Climate change, resource depletion, deforestation, loss of biodiversity, and pollution of land, air, rivers, and oceans impact the earth's current linear economic model (Greater London Authority, 2019). The construction industry is the largest user of materials and generator of waste in the economy. The industry needs to take the lead in supporting a shift towards a circular economic model (Greater London Authority, 2019). The significant aforementioned C\&D waste figures suggest that the design and construction sectors need to start embracing circular economy principles as standard practice as the built environment contributes to the climate emergency the earth is currently facing (Greater London Authority, 2019). The developed world has grown and flourished over time through a "take, make, and throw away economy" - a linear economy without adequately addressing and accepting the harmful consequences it comes with (Greater London Authority, 2019). Compared to a linear economy, the circular economy produces and maintains value by using materials for more extended periods and then reusing, repurposing, or recycling them at the end of the building's lifecycle, where the waste products become the basis of new materials (Greater London Authority, 2019).
A potential method that the construction industry could adopt is reusing demolished materials in new designs to reduce the overall C\&D waste going into the landfills. This is not a new sustainable design method. However, it has become more prevalent in recent years due to designers' increased awareness of climate change and its effects on the earth's raw materials. The idea of material reuse is simple. The building is deconstructed or demolished, and its materials and components are reused in a new design provided that they are uncontaminated, undamaged, and safe to use. Many building materials salvaged from demolition and building sites can be reused or recycled based on the capabilities of local recycling facilities, market demand for material reuse, the quality and condition of salvaged materials and components, time available for salvage, and emphasis put on reuse and recycling (BRANZ, 2020). 


\subsection{POTENTIAL BENEFITS OF MATERIAL REUSE}

The potential benefits of material reuse are described in three categories, environmental, financial, and social.

\subsubsection{ENVIRONMENTAL BENEFITS}

Reusing materials allows space to be saved in existing landfills and cleanfills, reducing the need for future landfills and cleanfills and their expansions (BRANZ, 2020). Pollution and energy consumption related to the manufacture of new building materials are also reduced when old materials are reused instead (BRANZ, 2020). By reusing materials, impacts such as noise, dust, and traffic on surrounding properties and streets are also reduced in the process of deconstruction or demolition (BRANZ, 2020).

\subsubsection{FINANCIAL BENEFITS}

Recent research suggests that when materialsare reused, the cost of purchasing new materials is reduced as there is less demand and need for them in the design (BRANZ, 2020). Another potential benefit to material reuse is that projects and contracts that specify waste reduction procedures are easily won as only select designers thoroughly prioritise the idea of reusing materials in their designs (BRANZ, 2020). Material reuse also allows the staff productivity to improveasworkefficiencies through accurate, detailed design, a focus on reducing work, temporary works and mistakes are also improved (BRANZ, 2020). Another potential financial benefit of material reuse is that waste disposal costs are reduced as there is less waste going into the landfills. For building materials and components salvaged in demolition, revenue can be earned (BRANZ, 2020).

\subsubsection{SOCIAL BENEFITS}

A potential social benefit from material reuse could be that the company's image could be enhanced through a high level of client satisfaction, which could also encourage repeat business in the future (BRANZ, 2020). Risks from hazardous materials could also be reduced in demolition due to more careful deconstruction techniques and proper removal and disposal (BRANZ, 2020). Through material reuse and the training and skills needed for it and deconstruction, there is potential for the innovation and challenges of material reuse to attract and retain employees who are willing to develop their skills in the industry (BRANZ, 2020)

While the research found suggests that there are many potential benefits to adopting the practice of material reuse, it is also important to take into consideration the disadvantages. For example, while there is a potential in financially spending less on new materials because planning to reuse, the literature studied fails to mention or give a clear idea on the costs for material recyclability in order to be able to safely reuse the materials in a new design. 


\subsection{FACTORS TO CONSIDER FOR MATERIAL REUSE}

In a traditional design process, the materiality of the building is thought about after the form. In this case of architecture created from reused materials, the process is inverted when the materials and availability dictate the design (Bahamon \& Sanjines, 2008).

Before the deconstruction process, the building's state must be identified to help classify the materials available at the demolition site and how much of these materials can be realistically reused. This is important as it identifies if any contaminated or damaged materials are not to be used (BRANZ, 2020). It is essential to factor in the different acceptable and unacceptable contamination levels and damage to the materials. This will influence the design and how much materials can be reused safely (BRANZ, 2020).
Other factors that need to be considered include the different costs related to material reuse, such as the cost of skip hire, the transportation costs of the demolished materials to the new site, and the cost of transport for the materials to be processed first (BRANZ, 2020). Another critical factor that needs to be considered is the proper sorting and handling requirements for each particular material types in the demolition site (BRANZ, 2020). It is also important to note the importance of practising and completing proper documentation, such as waste tracking and transfer forms (BRANZ, 2020). It is essential to complete these forms as it takes note of what material waste there is on-site, how much estimated material waste there is, and where it will end up to and for what purpose (BRANZ, 2020). 


\section{CHAPTER 4}

\section{WASTE IN HERITAGE AND WASTE CASTE STUDIES}




\subsection{HERITAGE PROBLEM}

Heritage New Zealand Pouhere Taonga is theorganisation responsible for promoting and maintaining the identification and protection of New Zealand's cultural heritage sites - done through a register of historic places (Heritage New Zealand Pouhere Taonga, 2020). Registration of a place/site does not equal automatic protection from demolition or modifications; registration acknowledges that the site is worth protecting (Heritage New Zealand Pouhere Taonga, 2020). Heritage New Zealand does not have the statutory power to prevent heritage sites from being modified, damaged, neglected, sold, or even destroyed (Heritage New Zealand Pouhere Taonga, 2020). A heritage title/status means that any building changes will affect its history and significance/value (Ministry for the Environment, 1997).
In heritage, conservation means maintaining and revealing a site's authenticity and integrity and involving the least possible loss of fabric or evidence of cultural heritage value (ICOMOS New Zealand, 2010). This shows that demolition of heritage significant buildings is frowned upon in the heritage sector. It is the last resort that organisations want to avoid as much as possible by trying other alternatives first. The ICOMOS NZ Charter explains that to maintain the place's authenticity and integrity, it is essential for all forms of knowledge and existing evidence of heritage values to be respected (ICOMOS New Zealand, 2010).

However, after natural disasters, like the Christchurch Earthquakes, demolition is the only option for heritage significant buildings that are no longer structurally safe to be standing. When total demolition is the only option for heritage buildings, it poses the question: what can be done to preserve the building's heritage value at the end of its life after demolition to avoid more C\&D waste going into the landfill? 


\subsection{HERITAGE IN MATERIALS}

Adaptive reuse is an example of an alternative to demolition that heritage organisationswill often turn to as it provides social benefits by revitalising familiar landmarks and giving them a new life (Mısırlısoy \& Günçe, 2016). Through heritage adaptive reuse, it ensures environmental and social benefits to the communities and helps to retain national heritage (Mısırlısoy \& Günçe, 2016). Adaptive reuse increases a building's life and contributes to sustainability as it lowers material, transport, energy consumption, and pollution (Bullen \& Love, 2011). However, the heritage sector often only recognises adaptive reuse as the only reuse method for preserving the heritage and does not acknowledge material reuse as another preservation method.

The lack of acknowledgement of material reuse as a genuine traditional mode of preservation practice indicates that the heritage sector is behind and has outdated views on ways heritage can be preserved. There is merely not enough literature and resources on heritage material reuse, which causes significant problem like climate change, global construction, and demolition waste are critical issues that the world is currently facing (Arlotta, 2019).

Demolition of heritage buildings is seen as environmental waste and disposal of local identity and cultural heritage (Misırlısoy \& Günçe, 2016). However, total demolition is sometimes the only option left for heritage buildings once they have achieved their maximum use and reached the end of their life span. At this point, the heritage sector often gives up, admits defeat, and continues with losing a heritage building.
In this case, material reuse could be a solution to preserve the demolished building's heritage value into a new design. With the many potential benefits outside of heritage mentioned earlier in the previous chapter, there is an opportunity to practice material reuse in the heritage sector. It would also be beneficial as it would provide the sector with an option to preserve heritage value after demolition (Arlotta, 2019). New tools and practices may be developed for the future and support communities facing increasing environmental change if heritage value through material reuse is understood and practised within the sector (Arlotta, 2019).

The upcoming case studies examined in this chapter identify the underlying question of where the significance of heritage lies - is heritage in the fabric or the form? This is a question best articulated in the practice of spolia, which refers to the idea of early Christian and medieval architectural reuse of stone building blocks, dating back to the times of Graeco-Roman antiquity (Kinney, 2011). Spolia is a form of architectural reuse that transmits historicity into the present and passes on meaningful messages to a modern audience that value material references to cultural history (Kalakoski \& Huuhka, 2018). The practice of spolia allows the audience to connect better with contemporary architecture, which has long been criticised for lacking a sense of time, place, and identity (Kalakoski \& Huuhka, 2018). As buildings get older and environmental awareness increases, many heritage buildings will receive lifecycle extensions, while others will have to be demolished for various reasons. Spoliation provides architects with an opportunity to preserve authentic historical material while still meeting the new challenges set by global environmental change (Kalakoski \& Huuhka, 2018). Spolia offers an opportunity to reuse existing building componentsinanarchitecturallyenriching and purposeful manner that respects the built heritage values (Kalakoski \& Huuhka, 2018). 
This image has been removed

by the author of this thesis for copyright reasons. Please refer to figure list for further details.

fig4.01 example of spolia at san procolo temple in verona

The idea of reuse had long been a routine practice in ancient societies as they could not afford waste (Kinney, 2011); the deconstruction and reuse of old construction materials in new buildings are now being prioritised in different countries to respond to the earth's climate emergency. While contemporary reuse is influenced mainly by the ecological and economic benefits it brings, this modern concept of 'spolia' also allows the possibility of transmitting the values of historical material of the original construction through the physical relocation of some of its components into a new architectural form (Kalakoski \& Huuhka, 2018). Current recycling practices such as contemporary material reuse achieve a much different outcome from traditional spolia as today's buildings have a much cleaner and smoother aesthetic and finish. Today's recycling and reuse process is more intensive than traditional spolia, which poses the problem of potentially losing the building's heritage value in the recycling process (Kalakoski \& Huuhka, 2018).
The underlying question of whether the significance of heritage lies in the fabric or theform isthereason why heritage material reuse is often challenged if it is a viable preservation method or not. It is debatable whether historicity and value lie in the object's material substances or whether it is a relative cultural construct, and there have been attempts to combine these two perspectives (Kalakoski \& Huuhka, 2018). Some authors view that material heritage is irrelevant and poses no significance (Taylor, 2015), while others recognise the importance of materiality for experiencing a building's historicity (Holtorf, 2013; Jones, 2010). Conservationists have debated for generations whether a heritage building's value lies in the original fabric or the form (Kalakoski \& Huuhka, 2018). As architectural conservation is based on the materialist theory by tradition, there is an underlying assumption that buildings express the past's values and history in their materiality (Jones, 2009; Jones \& Holden, 2008). However, contemporary material reuse presents the question of whether it will still be considered heritage or possess heritage value if a building's old and demolished construction materials go through an intensive recycling process before it is reused? 
This research's fundamental correlation in this investigation is the intrinsic heritage value often lost when recycling building materials. In traditional spolia, there is a clear distinction between the old and new as large chunks of materials and whole components traditionally went through minimal recycling processes before reused (Kalakoski \& Huuhka, 2018). In the case of contemporary material reuse, such as the recycled concrete case studies that will be examined in this chapter, the old concrete is finely crushed and goes through an intensive recycling process before it is mixed with new materials to create new recycled concrete.
This suggests that to achieve a more refined substance, the building's heritage value would be significantly lost in the process (Kalakoski \& Huuhka, 2018). The aesthetic of the distinct difference in materials of traditional spolia versus the clean and smooth finish of recycled concrete also makes it challenging to show that heritage material reuse was performed. However, a building's aesthetic should not determine whether heritage has been preserved and instead look beyond the physical and more so at the intention and desire to preserve the heritage through material reuse. Heritage value in material reuse should be a caseby-case basis where the materiality and the different recycling processes of each material and their different outcomes and finishes after being processed should be factored and the intention to preserve the heritage and historicity of the building. 


\subsection{CASE STUDIES}

These case studies look at different places worldwide that have focused and prioritised material reuse in their buildings to help combat C\&D waste.

\subsubsection{GERMANY (WASTE MATERIAL REUSE)}

Germany, particularly the capital city of Berlin, has only recently started to prioritise and focus on the importance of material reuse to help sustainably change the city's old habits. Angelika Mettke, a civil engineer and university professor at the Brandenburg University of Technology, pointed out her concern for the amount of raw material and energy needed to produce concrete slabs and how it was necessary to maintain them in the supply chain, especially in building construction (Jäger, 2016). Because of the raw material and high energy needed to produce new concrete, recycling concrete at the end of a building's life cycle and reusing the old concrete stops new raw materials and high energy to be produced. However, a problem with the idea of reusing old concrete instead of producing new concrete is that the concrete becomes contaminated through absorbing environmental pollutants over time such as oil, fuels, and paint through its surface (Jäger, 2016). Mettke and Walter Feess, researched different methods to reprocess concrete. Feess developed a washing system for polluted raw materials to be reclaimed and supplied for recycling (Jäger, 2016).
Using recycled concrete in new structures to help combat the waste generated through demolition does not create any future structural problems as recycled concrete has the same properties as newly poured concrete (European Commission, 2017). Berlin was already using more than 1 million recycled concrete tonnes during road construction in 2013 (European Commission, 2017). However, the demand for recycled concrete was still low and was not meeting its potential numbers, and the uptake in the building construction industry for recycled concrete was also slow (European Commission, 2017). In 2013, The State of Berlin initiated a pilot project as they wanted to address this and overcome the prejudices against using recycled concrete in building construction and wanted to stimulate demand for recycled concrete in the building materials market to increase (European Commission, 2017). The construction of the research and laboratory building for Life Sciences at the Humboldt University was Berlin's pilot project and offered the city an opportunity to include recycled concrete as a requirement in its design (European Commission, 2017). 
This image has been removed by the author of this thesis for copyright reasons. Please refer to figure list for further details.

This image has been removed by the author of this thesis for copyright reasons. Please refer to figure list for further details.

fig4.02 north campus of berlin humboldt university

fig4.03 the 4-storey humboldt university made from recycled concrete
The pilot project at Humboldt University was almost built wholly of concrete manufactured with a proportional amount of recycled aggregates (BFT International, 2015). CEMEX Deutschland, the lead building materials company for the project, developed a concrete of grade C30/37 with an aggregate fraction of $8 / 16 \mathrm{~mm}$ consistent with scrap concrete that is recycled professionally due to the new building's architecturally demanding design (BFT International, 2015). The Humboldt University pilot project's success led the State of Berlin to mandate the use of recycled concrete in all future public high-rise construction buildings, resulting in the replacement of around $100,000 \mathrm{~m} 3$ of standard concrete per year (European Commission, 2017). The State of Berlin encourages the recycling and reusing of building materials in future projects to minimise the generation of primary mineral raw materials and aid in conserving natural resources in the building construction industry (European Commission, 2017). 


\subsubsection{LONDON (WASTE MATERIAL REUSE)}

The construction industry in London alone consumes 400 million tonnes of material each year and accounts for $54 \%$ of waste (Greater London Authority, 2019). The demand for virgin materials and waste produced by the construction industry can be reduced by extending buildings' lives and recovering and reusing materials at the end of their life (Greater London Authority, 2019). It can also help protect the industry and London from the rising cost of materials and disposal of waste and the impact demolition and waste will have on noise and air quality, congestion, and land take (Greater London Authority, 2019).

London's construction industry needs to look at how to embed circular economy principles into built environment practices and adopt less resource-hungry approaches in constructing buildings in their everyday practices (Greater London Authority, 2019). London's Policy Plan has multiple aims and objectives to help the city transition to a circular economy model (Greater London Authority, 2019). By transitioning to a circular economy, Sadiq Khan, Mayor of London, has included in a draft London Plan ways to help the city transition to a circular economy model (Greater London Authority, 2019). Projects suchas IIford Community Marketshows the city's investments in the circular economy (Greater London Authority, 2019). This new market takes on the idea of a design for disassembly and materials reuse for the future as the Ilford Community Market has been designed to be taken apart and moved as needed (Greater London Authority, 2019). The market will occupy a neglected surface carpark in Ilford Town Centre for five years, and it is "designed to be dismantled and reconfigured on future 'meanwhile' sites" (Interrobang, 2020). The timber structure of the market was designed and detailed to avoid below-ground foundations so that it will "leave the site undamaged and free from large wasteful, energy-intensive concrete foundations" at the end of the market's stay in Ilford. This market shows how the circular economy can make a temporary asset more valuable (Interrobang, 2020).

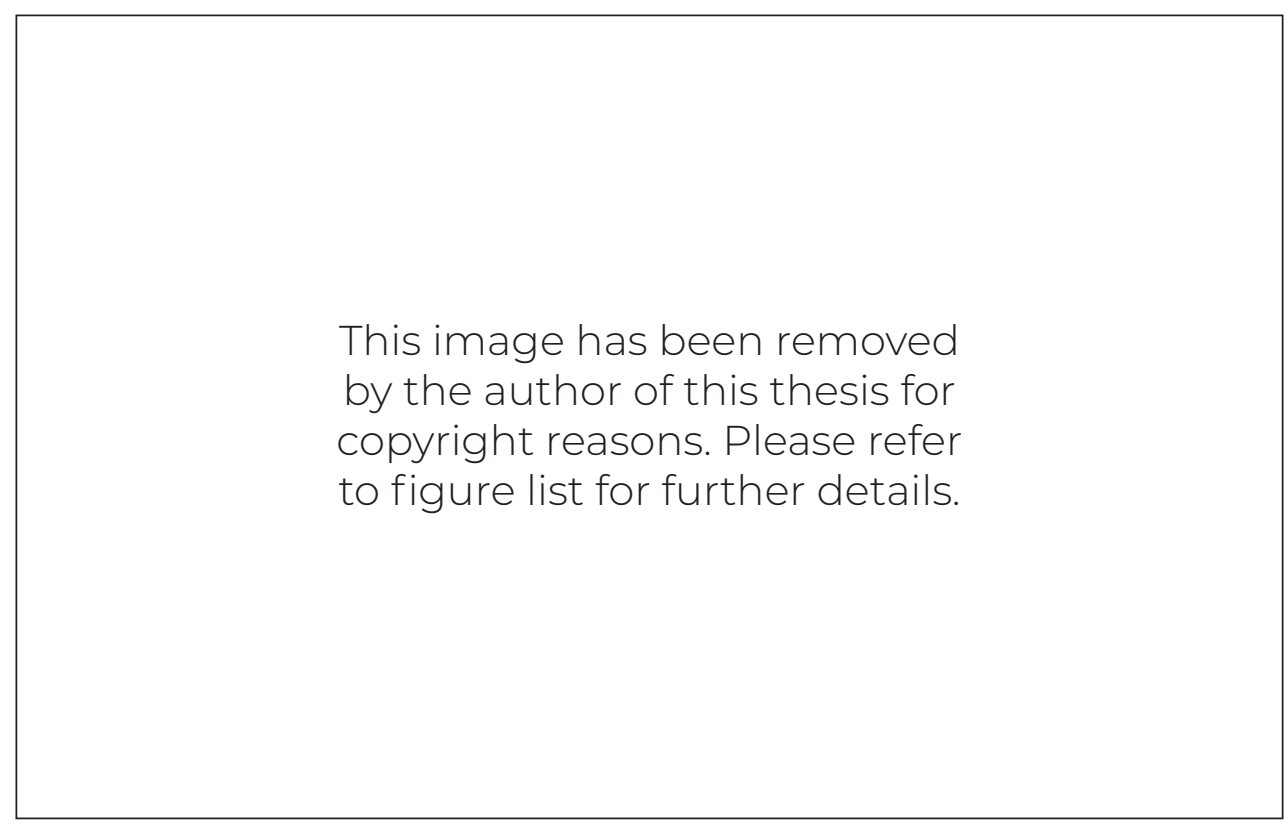

fig4.04 interior view of ilford community market 
This image has been removed by the author of this thesis for copyright reasons. Please refer to figure list for further details.

If circular economy principles are successfully adopted in London, it could provide the city with many potential benefits (Greater London Authority, 2019). As many as 12,000 new jobs could be created, and between $£ 3$ billion and $£ 5$ billion in growth could be contributed to London by 2036 (Greater London Authority, 2019). By increasing the productive use of materials and reducing material and disposal costs, building developers will also benefit from material optimisation and waste minimisation (Greater London Authority, 2019). They can uncover different opportunities to save millions of pounds by reusing excavation and demolition waste on-site and reducing waste from construction (Greater London Authority, 2019). The city will also benefit as a circular economy would reduce the quantity of new material imported into London and the amount of waste exported to surrounding boroughs. Overall, this will help reduce the city's reliance on imported material and exported waste and free up and make better use of land set aside for waste management (Greater London Authority, 2019). 


\subsubsection{ZURICH (WASTE MATERIAL REUSE)}

In the late 1990s, Zurich started to monitor their C\&D waste, and the city looked for different ways to put demolished concrete in their landfills to better use. C\&D waste is one of the most significant waste streams in the European Union, where 25-30\% of all waste generated consists of C\&D materials that can be recycled, such as concrete, bricks, gypsum, wood, glass, and metals (European Commission, 2019). In 2002, Zurich's first-ever recycled concrete public building was built, the Im Birch School(Gehrig, 2019). This building was the city's initial experiment for recycled concrete and was conducted with the help of a local concrete producer and included quality and strength testing, with the final building containing 80\% recycled concrete (Gehrig, 2019). Since their first recycled concrete building's success, it became mandatory in 2005 that all public buildings in Zurich were to be built from recycled concrete in line with their building standards (Gehrig, 2019).

This image has been removed by the author of this thesis for copyright reasons. Please refer to figure list for further details.
This image has been removed by the author of this thesis for copyright reasons. Please refer to figure list for further details.
This image has been removed by the author of this thesis for copyright reasons. Please refer to figure list for further details. 


\subsubsection{ANKARA, TURKEY (HERITAGE MATERIAL REUSE)}

In 2015, located in Castle Square, Ankara's oldest settlements, three historical Ankara houses were transformed into the Erimtan Museum building while preserving their historical and architectural values (Erimtan Archaeology And Arts Museum, 2020). The three historical houses that compose the Erimtan Museum are from the 18th century and hold much history within their materiality (Erimtan Archaeology And Arts Museum, 2020).

These three houses were completely dismantled and rebuilt as their state of ruin was too far to fix (Meyer, 2019). The new museum building is not a replica. However, it is instead a modern interpretation that "follows its predecessors in volume and expression and sports the same intricacies of masonry techniques for its heavy grey stone walls" (Meyer, 2019). To achieve the reuse of the historic houses' old rocks, the rocks were numbered before demolition

This image has been removed by the author of this thesis for copyright reasons. Please refer to figure list for further details.

fig4.09 exterior elevation photo of erimtan museum, showing the reused stones

fig4.10 copper door entrance to erimtan museum and replaced in their original locations in the new museum building (Meyer, 2019). The reuse of the materials and the history of the three Ankara houses inspired the new architecture, particularly the mortar joints, the depth of the window frames, the order of the roof tiles, and the thickness of the threshold stones (Meyer, 2019). The Erimtan Museum also uses concrete, terracotta, copper, cast iron, and wood to complement the Ankara stone and shows a balance between historic and contemporary details (Meyer, 2019).

Reusing the three houses' materials into the private museum demonstrates how this design blurs the lines between heritage preservation, restoration, conservation, and reconstruction (Meyer, 2019). The concept of using spolia has proven to be useful in this design. It shows how the Erimtan Museum is an elegant example of contemporary spolia in a sector that completely overlooks material reuse's validity as a heritage preservation method (Meyer, 2019).

This image has been removed by the author of this thesis for copyright reasons. Please refer to figure list for further details. 


\subsection{EVALUATION OF FINDINGS}

To respond to the global climate emergency, material reuse as a potential genuine preservation practice mode remains unacknowledged by the heritage sector, showing the sector's outdated views on ways heritage could be preserved. It has so far been identified in this research portfolio how valuable material reuse could be if implemented. In highlighting the different potential benefits for both non-heritage and heritage buildings and explaining how the case studies have successfully practised material reuse, this value is further emphasised. It is inevitable for heritage buildings to be demolished and lost; however, this chapter shows that heritage-significant buildings' lifecycle does not have to end in demolition. There is a potential to preserve history through the reuse of materials. Because architectural conservation is traditionally based on the materialist theory, there is an underlying assumption that heritage lies in the building's fabric rather than the form, as values and history of the past are expressed in the materiality (Jones, 2009; Jones \& Holden, 2008). This further suggests material reuse should be accepted as a preservation method, as salvaging construction materials during demolition and reusing them for a new build could be a way heritage and history of the demolished building could live on. This research recognises that in heritage material reuse, the right to preserve heritage value should not be determined by the physical aesthetic of the new build's outcome. However, rather heritage value should instead be determined by the historic material reused and the intention and desire to preserve heritage.

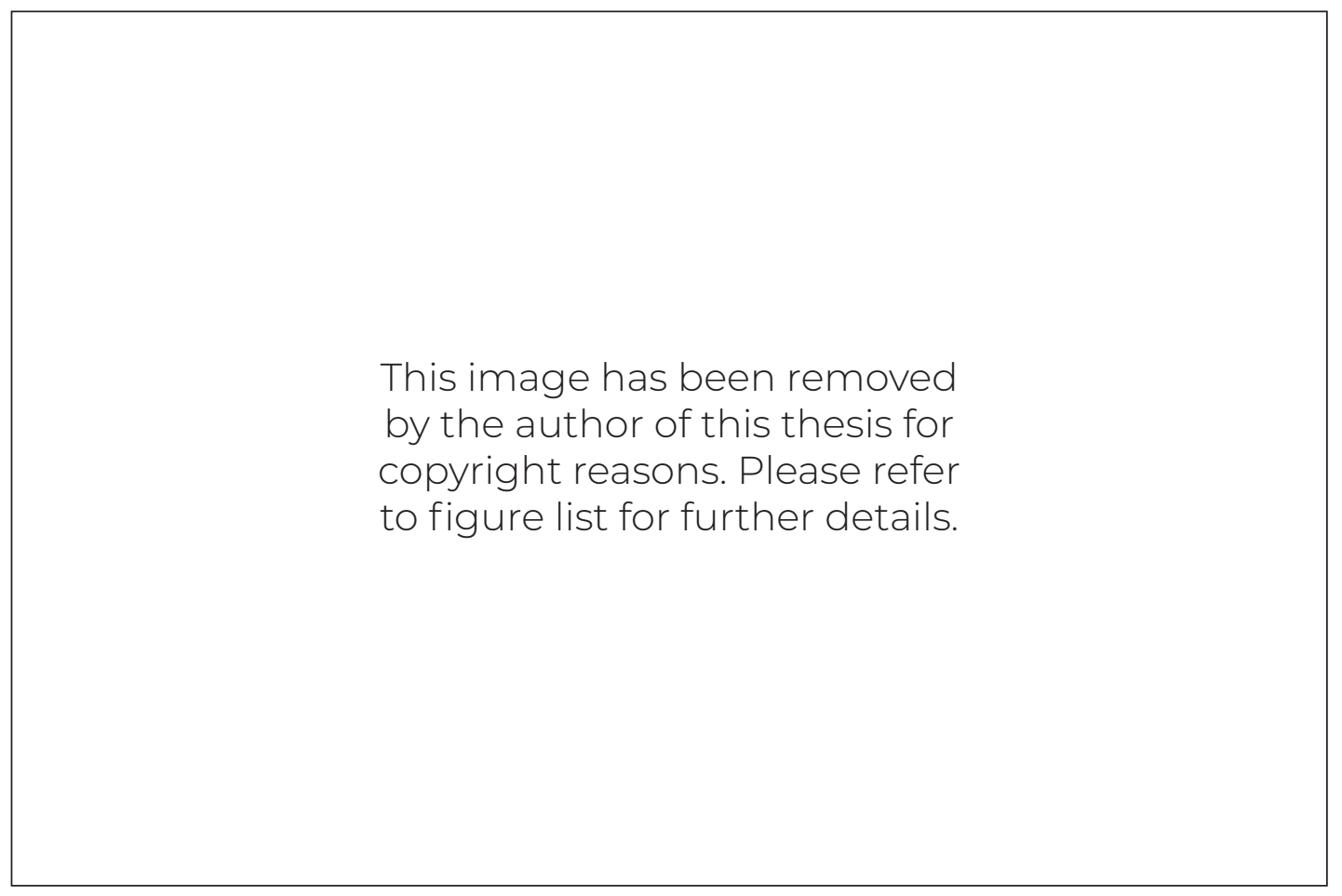

fig4.11 example of contemporary spolia, erimtan museum 


\title{
CHAPTER 5
}

\author{
SACRED \\ ARCHITECTURE \\ CASE STUDIES
}




\subsection{CASE STUDIES}

This chapter looks at three uniquely different churches, analysing how these churches have been designed to respond to celebrating the liturgy and how they address the church's meaning and purpose via their form and materiality.

\subsubsection{SHRINE OF THE VIRGIN OF LA ANTIGUA}

\section{Otxotorena Arquitectos Alberite, La Rioja, Spain 2009}

The Shrine of the Virgin of La Antigua's site was a gift from the town council to the parish (Pallister, 2015, p. 52). It is intended for the building to accommodate both private uses by individuals or small groups and large groups of pilgrims (Pallister, 2015, p. 52).

This image has been removed by the author of this thesis for copyright reasons. Please refer to figure list for further details.
Essentially a series of outdoor rooms, the occupant approaches the church via a concrete pathway and "entering under a piloti over which a flat concrete extends above the edge of the path beneath" (Pallister, 2015, p. 52). The occupant then encounters a series of preserved stone arches that runs parallel to the new concrete elevation once under the canopy and greets the visitor as they approach the Church (Pallister, 2015, p. 52). The villagers of Alberite rescued the series of preserved archways from a building that was being demolished (Pallister, 2015, p. 52). As the brief for the new church's design specified that ruins of the old should be incorporated in the design, the remnants of a previous building helped follow the request of the design brief (Pallister, 2015, p. 52). The stone archways in the new design allow the history of the old building to be continued.

fig5.01 extra volume on side elevation providing extra height inside 
This image has been removed by the author of this thesis for copyright reasons. Please refer to figure list for further details.

fig5.02 salvaged archways reused in the design
This image has been removed by the author of this thesis for copyright reasons. Please refer to figure list for further details.
This image has been removed by the author of this thesis for copyright reasons. Please refer to figure list for further details.
As the visitors walk along between the archways and the concrete elevation, they are taken to a small chapel with four simple pews (Pallister, 2015, p. 52). The idea of compression and release is played within the architecture, helping evoke a feeling of peace and space inside the chapel (Pallister, 2015, p. 52). This was done by part of the chapel opening up to an extra volume placed on the side elevation, which provides the chapel with a generous floor-to-ceiling height (Pallister, 2015, p. 52). Rays of sunlight are also cast onto the concrete walls and floor of the building via the vertical concrete fins on the exterior façade bringing light into the chapel (Pallister, 2015, p. 52).

fig5.04 corridor shot showing the old vs new in materiality 


\subsubsection{ST MORITZ CHURCH}

\section{John Pawson}

\section{Augsburg, Bavaria, Germany}

2013

St Moritz Church has been built since the Holy Roman Empire and has been through multiple restorations and modifications in its lifespan (Pallister, 2015, p. 74). It was originally built as a Romanesque basilica but has been reworked in the Gothic and Baroque styles over the years (Pallister, 2015, p. 74).

The architect'sapproach in 2014 was to strip the church back to its fundamentals and createanarchitecturethat "respectsitspast while creating something new, functional, and appropriate" (Pallister, 2015, p. 74). Pawson's main focus in the architecture was subtraction and clarification, where much of the structure is retained but stripping back the ornamentation in the space and manipulating how light is used and bounced around in the building (Pallister, 2015, p. 74). fig5.05 interior view of st moritz's nave showing how bright and light the space is

fig5.06 rounded arches along the side of the nave of st moritz
This image has been removed by the author of this thesis for copyright reasons. Please refer to figure list for further details.
This image has been removed by the author of this thesis for copyright reasons. Please refer to figure list for further details. 
This image has been removed by the author of this thesis for copyright reasons. Please refer to figure list for further details.

fig5.07 st moritz minimal sanctuary to not distract the churchgoers

By using laminated onyx panels on the apse windows, a diffused and ethereal light is brought into the Church (Pallister, 2015, p. 74). Concealed LED light fittings in the apse and nave also gradually fill the church with a yellowish light after dusk (Pallister, 2015, p. 74). St Moritz Church has a very minimalist palette, and the only colours that deviate from it are the light beige Portuguese limestone used for both the altar and the floor, as well as the darkstained wood used for the pews, altar stalls and the organ surround (Pallister, 2015, p. 74).
By stripping the building down, the renovation work by Pawson done in 2013 allow the occupants to focus on the function of the church and the feelings evoked inside without getting distracted by the clutter of ornamentation. 


\subsubsection{ST JEAN VIANNEY}

\section{Trahan Architects}

Baton Rouge, Louisiana, USA 2000

This sacred space is distinguished via the simplicity of form and material and has been designed in response to Vatican II's changes (Feireiss \& Klanten, 2010, p. 135). Stripped of ornament emphasises the sanctuary's central focus on the gathering experience, and honest expression of materials and structure highlights the space's spiritual environment (Feireiss \& Klanten, 2010, p. 135).
While the Catholic Church has traditionally put a large focus on transcendental architecture as a way to reflect and enrich church ceremony rituals, the Second Vatican Council has shifted the focus and put an emphasis on the idea of the community gathering to celebrate the liturgy (Feireiss \& Klanten, 2010, p. 135). As a response to Vatican II, St Jean Vianney's octagonal centralised plan allows the focus to be on the raised altar, with all the pews facing this point as a recognition of the importance of witnessing the celebration of the sacraments (Feireiss \& Klanten, 2010, p. 135).

This image has been removed by the author of this thesis for copyright reasons. Please refer to figure list for further details. 
In the design, light and nature function as design elements that aid in stimulating and engaging the senses (Feireiss \& Klanten, 2010, p. 135). The natural light also activates and brings life to the space and further reinforces the sense of community in the design (Feireiss \& Klanten, 2010, p. 135).

This image has been removed by the author of this thesis for copyright reasons. Please refer to figure list for further details. fig5.09 entrance and baptismal font

fig5.10 simplicity in the use of materials in the church

fig5.11 interior view of st jean vianney
The materials used in St Jean Vianney are authentic, pure, and empty of decoration or distraction (Feireiss \& Klanten, 2010, p. 135). The use of carefully detailed concrete, glass, wood, and steel provides a backdrop for the liturgy celebration (Feireiss \& Klanten, 2010, p. 135). With these materials in the building, the natural light plays around the space and acts as an architectural element and deepens the spiritual experience being presented by the building (Feireiss \& Klanten, 2010, p. 135).

This image has been removed by the author of this thesis for copyright reasons. Please refer to figure list for further details.
This image has been removed by the author of this thesis for copyright reasons. Please refer to figure list for further details. 


\section{CHAPTER 6}

SITE ANALYSIS 


\subsection{SITE BACKGROUND}

\subsubsection{CURRENT CATHEDRAL SITE}

The Cathedral of the Blessed Sacrament has sited on Barbadoes Street in Central Christchurch since 1905 . Its 64 metre length and 32metre width, and its 47 metre dome and towers make this Cathedral a landmark for being one of the larger churches in New Zealand. This building required approximately $3400 \mathrm{~m} 3$ of Oamaru stone, $560 \mathrm{~m} 3$ of Mount Somers stone, $110 \mathrm{~m} 3$ of concrete, and about 90 tons of steel to construct the grand Cathedral it is known for (Hanrahan, 2004). This buiding's design and construction include

This image has been removed by the author of this thesis for copyright reasons. Please refer to figure list for further details. concrete heart walls faced with stone, Italianate green copper-roofed dome, concrete arches, ceilings lined with prefabricated compressed zinc panels, colonnades of ionic columns in the nave, kauri wood structure, and stained-glass windows (Hanrahan, 2004).

Around the Barbadoes Street site currently houses two high schools, Catholic Cathedral College and Marian College sharing a school field directly behind the Cathedral, and the parish office and residential house for the Bishop adjacent to the Cathedral.

fig6.01 catholic basilica and its surroundings pre-earthquakes

fig6.02 aerial photo of new site

fig 6.03-6.04 the new site is currently a car park as it has been empty since 2011

fig6.05 map showing old vs new site 


\subsubsection{NEW SITE}

The new site that the Diocese has purchased for the new Cathedral is in the city centre and covers two large blocks of land along Armagh Street, adjacent to Victoria Square, which has sat empty and become temporary car parks since the 2011 earthquakes. This new site hosted a multitude of commercial buildings - both offices and stores - and their histories.
Bishop Paul Martin, the current Catholic Bishop of Christchurch, has stated that the new Cathedral planned near Victoria Square is expected to accommodate up to 1000 people and be completed by 2025 (Radio New Zealand, 2019). As the site covers two large blocks of land that have sat empty since 2017, the Diocese is planning a $\$ 500$ million project on site that has not only the Cathedral but also a pastoral centre and community hub, a primary school for a relocated St Mary's Primary School, offices for the Catholic Diocese, residential accommodation for the clergy, and a multi-storey car park building for approximately 600 cars (Radio New Zealand, 2019).

This image has been removed

by the author of this thesis for copyright reasons. Please refer to figure list for further details.
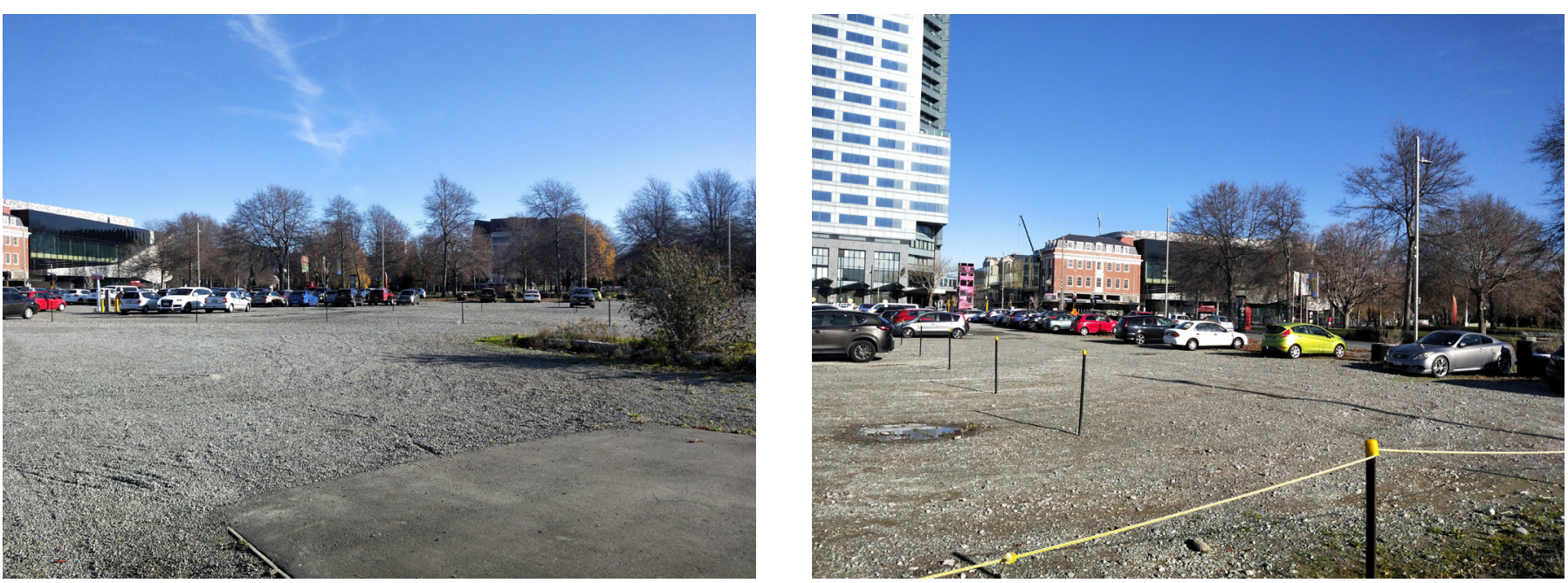



\subsection{SITE ANALYSIS}

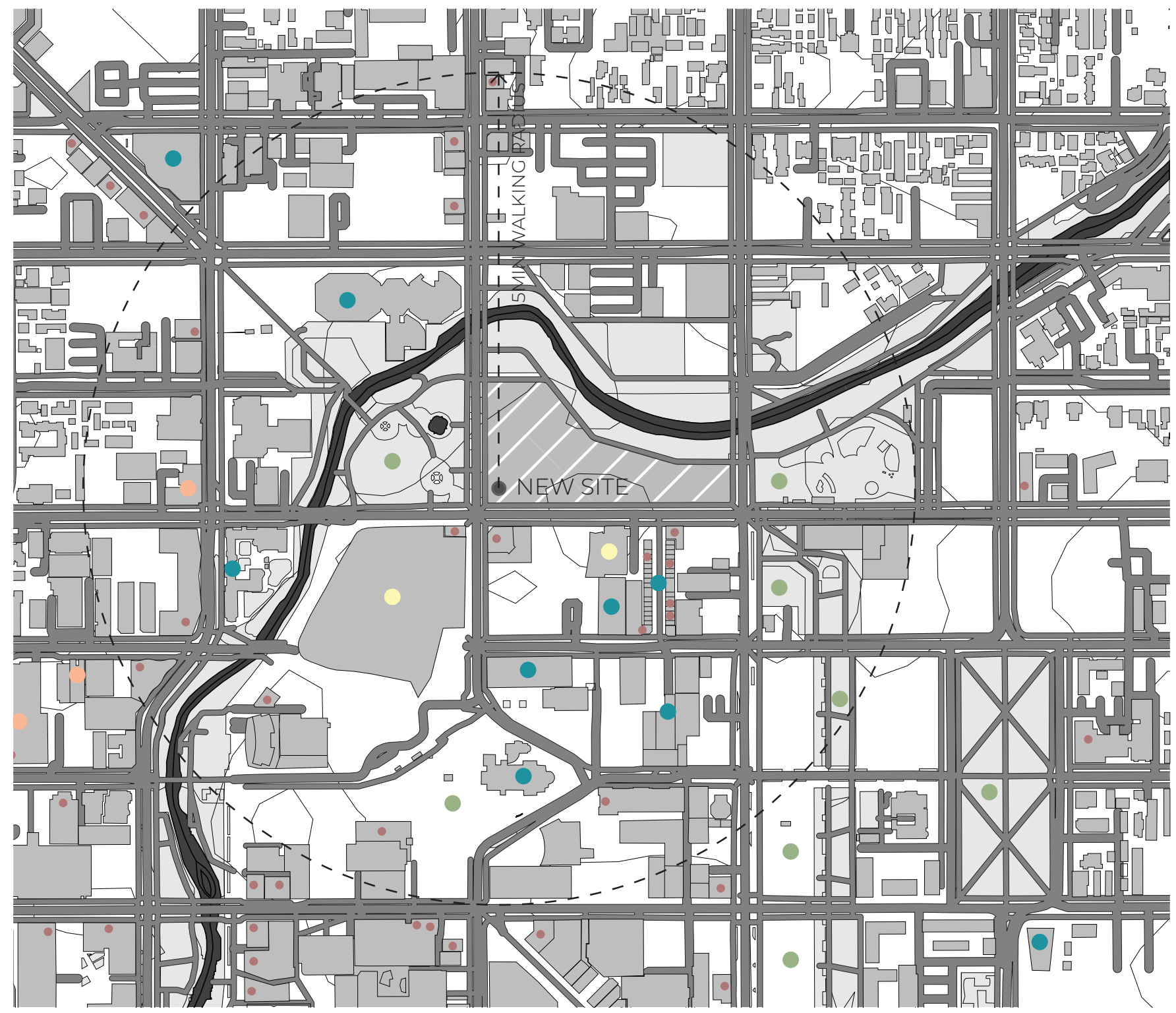

Cafe/Restaurants

Community Centres

Landmark

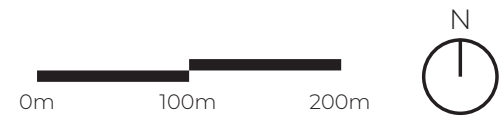

- Gallery/Museum

Park 

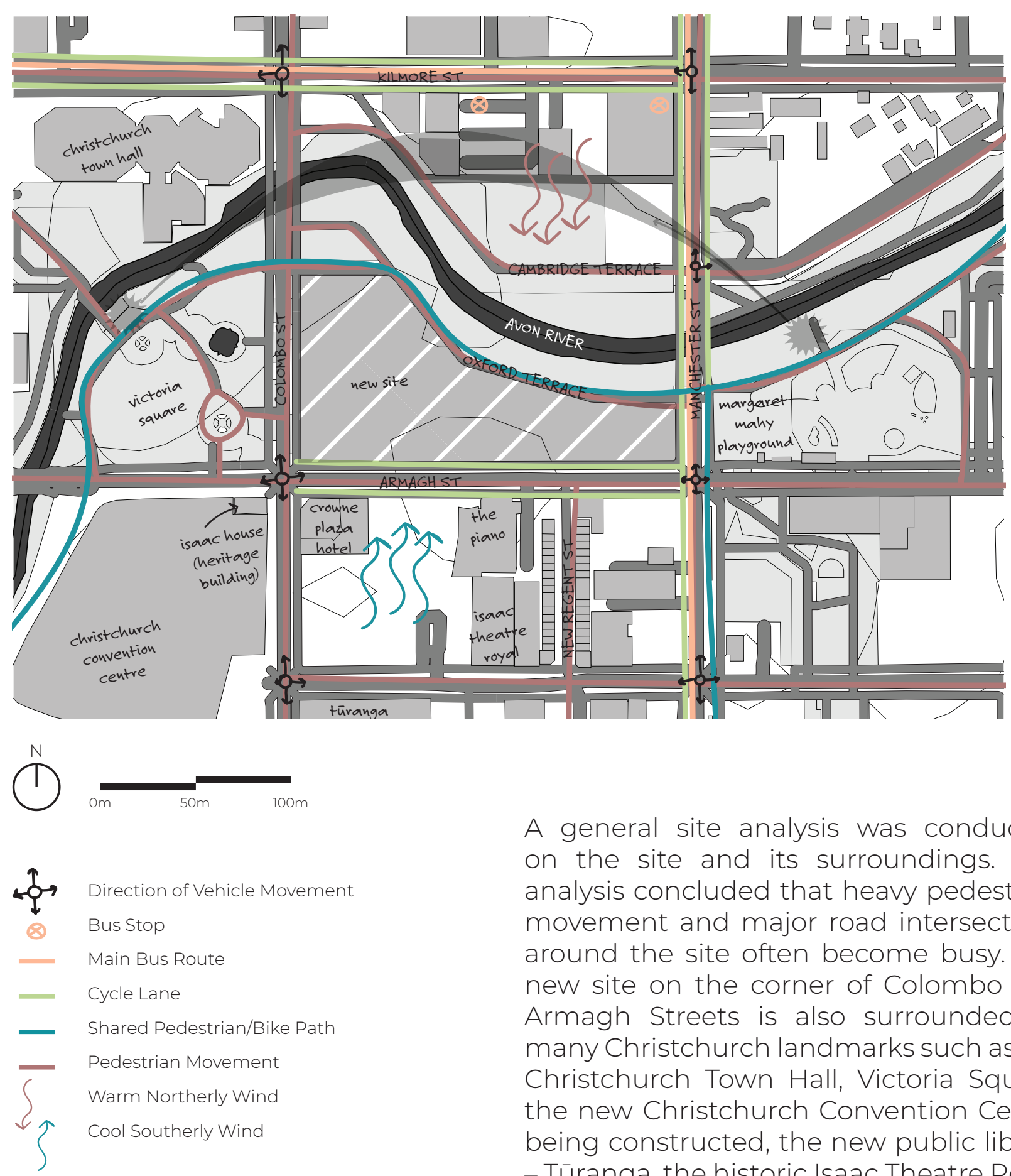

A general site analysis was conducted on the site and its surroundings. This analysis concluded that heavy pedestrian movement and major road intersections around the site often become busy. The new site on the corner of Colombo and Armagh Streets is also surrounded by many Christchurch landmarks such as the Christchurch Town Hall, Victoria Square, the new Christchurch Convention Centre being constructed, the new public library - Tūranga, the historic Isaac Theatre Royal, Margaret Mahy Playground, and the iconic New Regent Street. The new site being closer to the centre of the city allows access to more amenities around. It also allows happening around the new site the proposed Cathedral an opportunity to be considered an "everyday" building as it will be so accessible to people being in the centre of the city, and visitors would not have to go out of their way to visit the space. 


\subsection{SITE IMAGES}

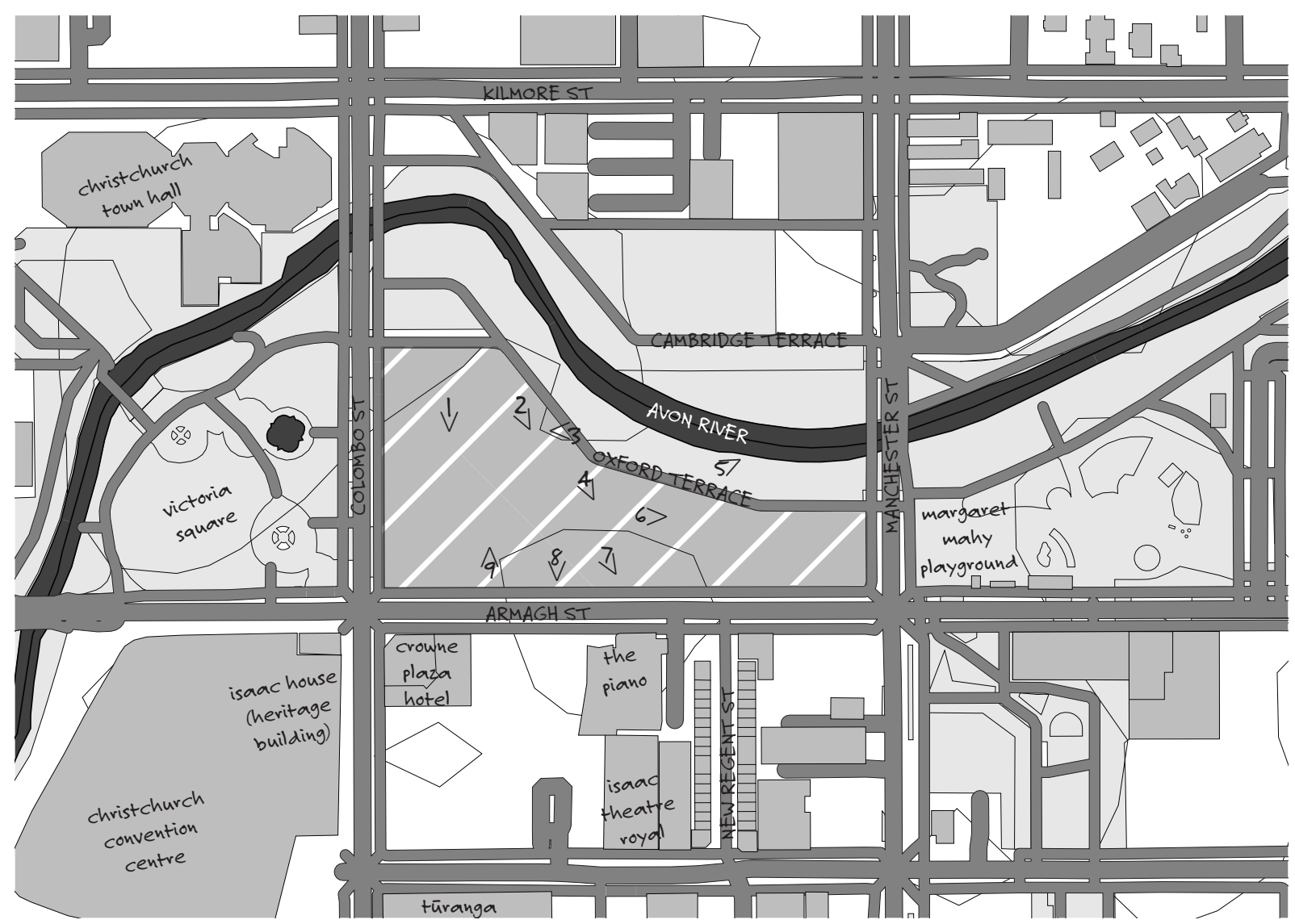

fig6.08 map showing points of views

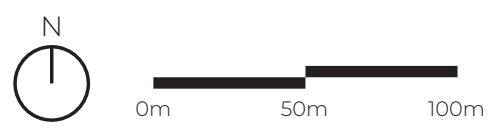

These images show the site as it currently is and its surroundings and represent the different points of views when on-site. 

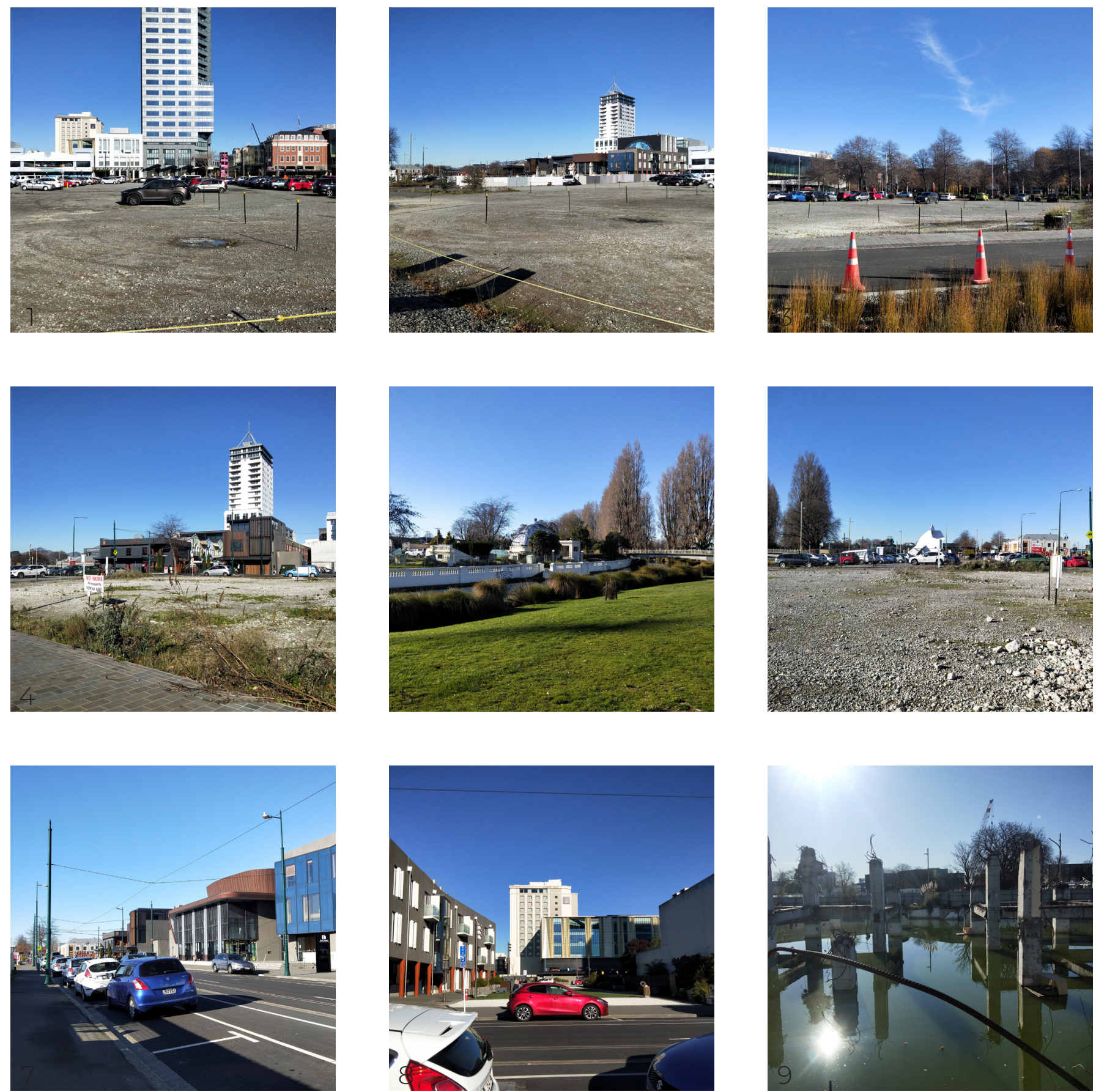

fig6.09-6.17 different views around the site 


\subsection{DESIGN MASSING OF NEW BUILDINGS ON SITE}

As the new site spans across two large blocks of land and is proposed to have more buildings on it other than the Cathedral, it was crucial to section off the site to propose how the different amenities could fit on site. This is done by planning the other buildings as building masses in the shape and size, and placement that could possibly work on site. Although a speculative approach on the site and other buildings was done, site massing was vital as it made it easier to understand what was going to go on around the Cathedral. It showed how a proposed Cathedral design could interact and link with the other buildings on-site and respond to the site accordingly.

In this proposed site massing plan, the Cathedral is situated on the west-most part of the site along Colombo St, the front of the Cathedral facing Armagh St. It was decided to place the Cathedral here as this side has more landmarks around and would allow the Cathedral to be part of the city and its surrounding public spaces. The Cathedral placement also allows the building to be a prominent piece of architecture occupying the site and makes it highly visible to the public. Beside the proposed placement of the Cathedral is the community centre/ pastoral hub that the Diocese is wanting to have for recreation purposes and other events.
The Cathedral and the community centre are setback from the roads as a forecourt/ paved plaza in front of these buildings could bring people onto the site and enjoy the space without entering the buildings. This small plaza could act as an extension of Victoria Square and allow people to publicly use the space and admire being in the Cathedral's presence without actually going inside and will allow people to walk around the Cathedral and admire its grandeur from different points of views. The proposed forecourt will also allow people to gather outside before and after church ceremonies.

Adjacent to the community centre and the plaza, a tree-lined fence provides privacy and access for the pastoral office, pastoral residency, and the relocated St Mary's Primary School. Fencing off these buildings allows separation between the public and private spaces on-site and allows security for the school children. A multi-storey carpark building would occupy the east-most section of the site. It was essential to keep the carpark as separate from the Cathedral as possible so that no other surrounding buildings, apart from the existing hotel directly in front of Armagh St, would tower over the Cathedral. It was essential to make sure the Cathedral has that sense of grandeur and power, and this was not going to be possible if the carpark building was situated closer to the Cathedral on site. 


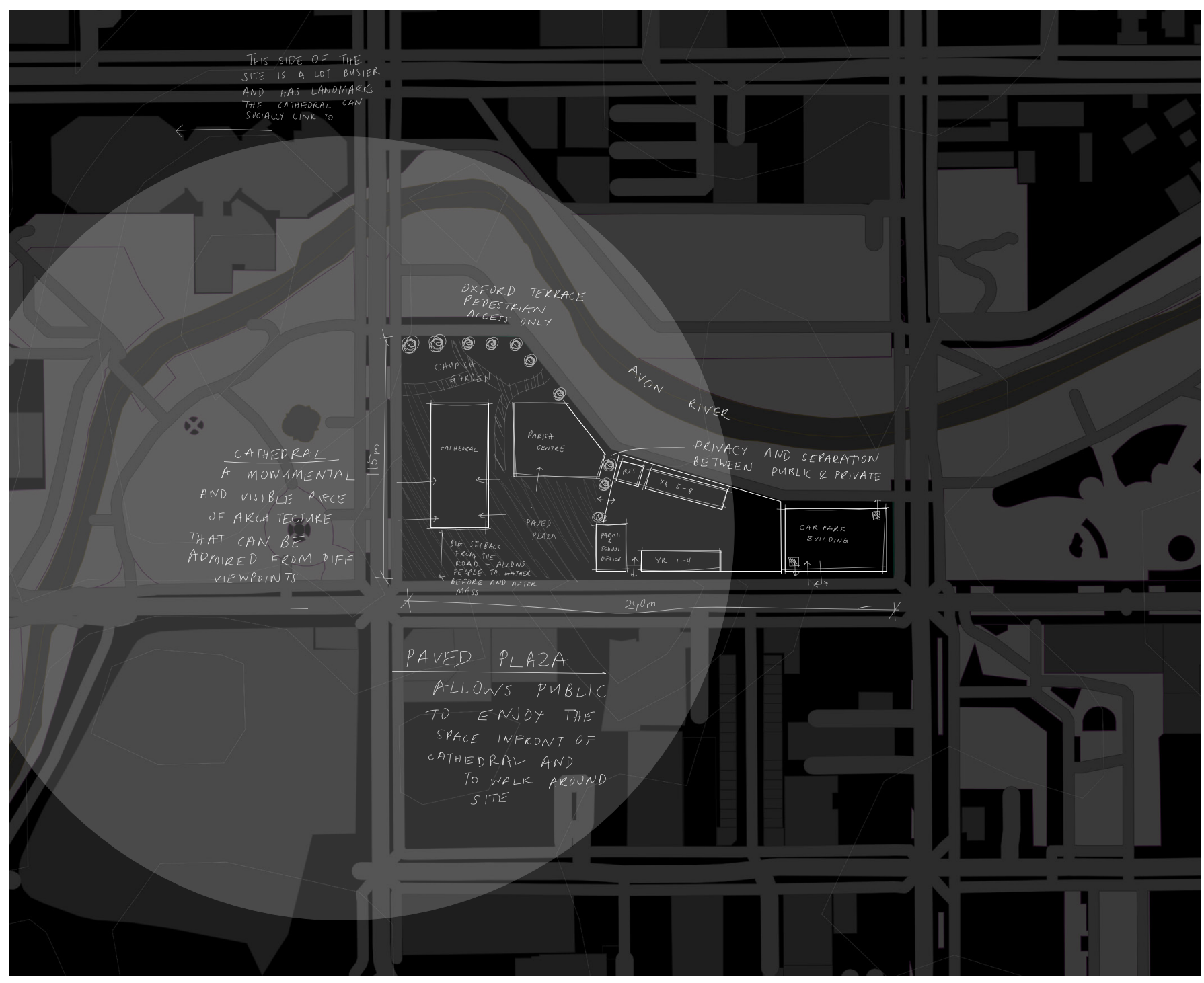

fig6.18 massing plan for the different proposed buildings on new site

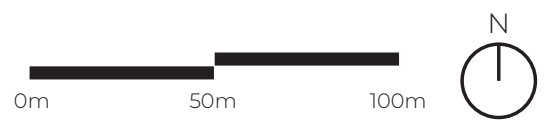




\section{CHAPTER 7}

DESIGN STRATEGY 


\subsection{CATHEDRAL SITE ANALYSIS FROM DESIGN MASSING}

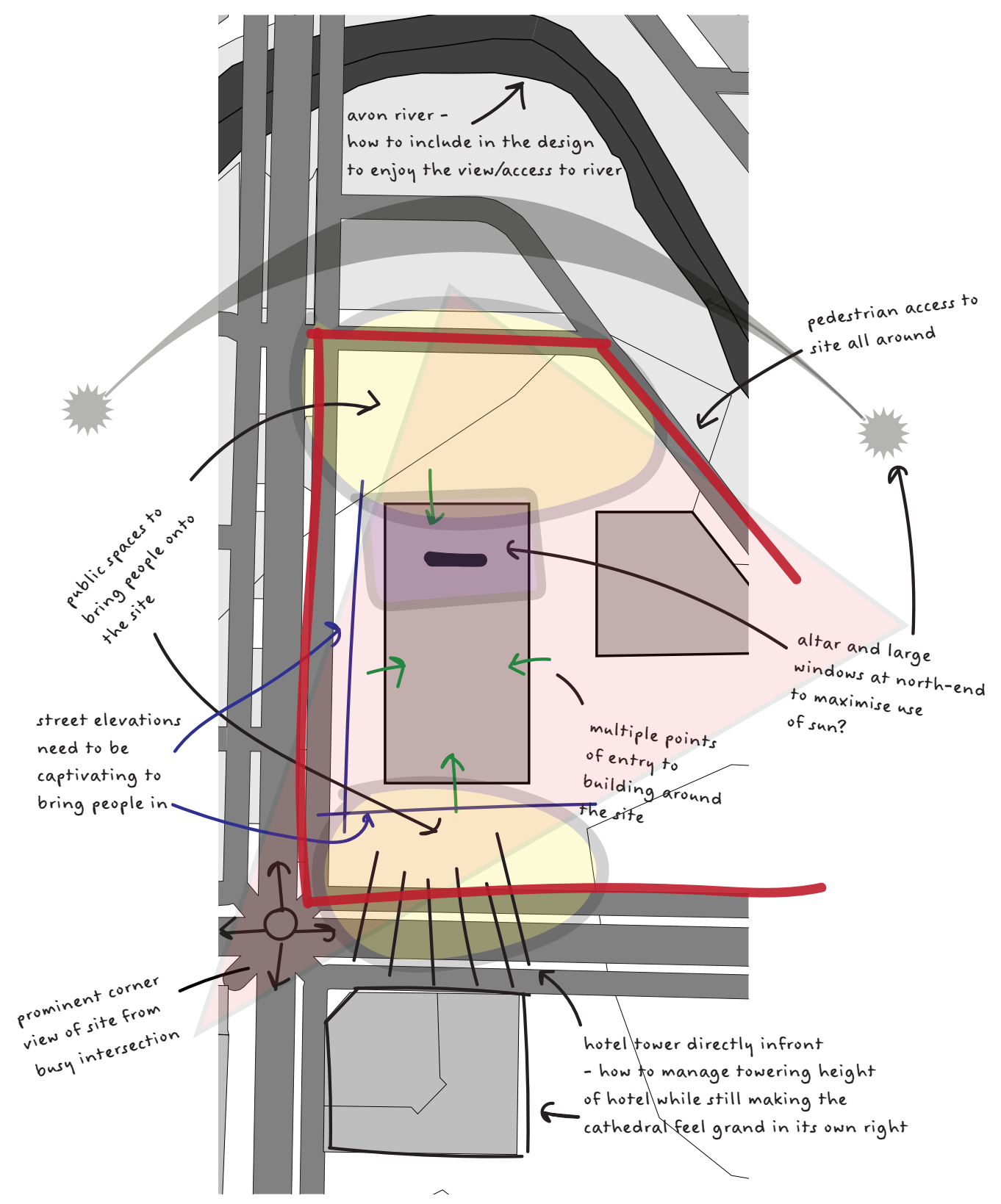

$C^{N}$

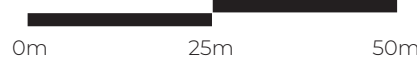

By sectioning off the site in the previous chapter, the specific placement of the proposed Cathedral can be focused on and further analysed to understand how the design could fit appropriately on the site. This allows the planning and design stage to begin. 


\subsection{ARCHITECTURAL NARRATIVE}

The narrative of the architecture is to be directed by the reuse of materials. Thinking about how and where these materials can be reused and how they can bring forth meaning and tell the Cathedral's history and past is the prominent influence on the design process.

\subsection{MATERIAL OPPORTUNITIES}

\subsubsection{Copper Dome}

- Reuse dome as is and have another roof dome. Is it structurally safe to be reused?

-Incorporate the dome inside the building somehow like the Wellington Supreme Court

- Use as a central point for outdoor garden (e.g., pergola)

- Turn the copper roof into panels and use as feature cladding

- Use as fragmented exterior shell for side chapel. Is it big enough to be turned into a side chapel?

\subsubsection{Limestone}

- Main material that needs to be reused for wall cladding (exterior and interior)

-Potential to be used as fencing

-Potential to be used as paving
Inspired by the Church's history and how it successfully operates also influences as the design aims to create a new Cathedral that respects tradition and is functional and appropriate to its setting. Evoking a feeling of simplicity, elegance, and transcendence within the architecture and focusing on the community and celebration of the liturgy are critical goals for the design.

This image has been removed by the author of this thesis for copyright reasons. Please refer to figure list for further details.

fig7.02 copper dome of catholic basilica

fig7.03 limestone used throughout the cathedral after the earthquakes

This image has been removed by the author of this thesis for copyright reasons. Please refer to figure list for further details. 


\subsubsection{Concrete}

-Floor Slabs

- Walls

-Primary Structure - columns and beams

fig7.04 concrete rubble in the cathedral after earthquakes
This image has been removed by the author of this thesis for copyright reasons. Please refer to figure list for further details.

This image has been removed by the author of this thesis for copyright reasons. Please refer to figure list for further details.

-Feature ceiling

fig7.05 kauri wood roof framing exposed after earthquakes

\subsubsection{Pressed Zinc Sheets}

-Feature Wall

-Feature Ceiling - paint over in white to give off modern feel and help in brightening space up

fig7.06 pressed zinc sheet ceiling in the nave left exposed after earthquakes

\subsubsection{Ionic Columns}

- Outdoor Garden Stations of the Cross - Gazebo

-Pergola

fig7.07 columns still standing after surviving earthquakes
This image has been removed by the author of this thesis for copyright reasons. Please refer to figure list for further details. removed by the author of this thesis for copyright reasons. Please refer to figure list for further details.
This image has been 


\section{CHAPTER 8}

CONCEPT DESIGN 


\subsection{CHURCH'S DESIGN INTENTION}

Much of how the Catholic Church operates now changed because of the Second Vatican Council. As a result, ecclesiastical architecture has evolved to respond to Vatican II changes in the church. At the heart of this reform, "active participation" within all people in the liturgy is encouraged. The laity is now welcomed to take more active and visible roles in the assembly (Schloeder, 1998, p. 18). They are invited to participate in the liturgy as servers, readers, commentators, and choir members (Schloeder, 1998, p. 18).

As Vatican Il's goal is to enrich faith, it is crucial to understand how the architecture can respond and achieve this in the design. Places of worship should be fit to celebrate the liturgy and ensure the faithful's active involvement, the way Vatican II intended (Schloeder, 1998, p. 42). It is essential to follow the church's direction when designing for the liturgy. To achieve this, it is imperative to work and explore the different levels for ecclesiastical architecture: the functional, the social, the symbolic, the qualitative, and the aesthetic as they are all necessary for the enrichment of faith (Schloeder, 1998, p. 42).

As churches hold certain reverence and honour within them, churches are not for "inordinatearchitectonicexperimentalism, nor for bizarre or idiosyncratic architecture" (Schloeder, 1998, p. 42). Universality, social nature, and appropriateness are qualities and values that concern and influence the church's architecture. It is essential to create a design that expresses these universal values that the church holds (Schloeder, 1998, p. 43). This means that the building designed should be beautiful, well-reasoned, carefully detailed, and most importantly, adequately constructed (Schloeder, 1998, p. 43). Additionally, it also means that the building form should also express the existential nature of the church and express the unity of the people of God (Schloeder, 1998, p. 43). The design needs to encourage prayer, create a sense of the sacred, and reflect the holiness of the holy mysteries and sacraments (Schloeder, 1998, p. 43).

Creating a space that evokes the sacred and allowing for and encouraging transcendence may be one of the biggest challenges a contemporary church architect may face (Schloeder, 1998, p. 46). It raises the question, how does one design for transcendence? Churches should respect that "mankind is both body and soul, with temporal and eternal dimensions" (Schloeder, 1998, p. 46). Therefore, the architecture should speak to "the whole human being - body and soul, will and intellect, head and heart, rational and emotional, and aesthetic faculties" (Schloeder, 1998, p. 46). When designing for transcendence, the architecture should create an environment that encourages corporate and private prayer for the human soul, and sacred architecture should seek to transcend space and time seeking timelessness rather than temporality (Schloeder, 1998, p. 46). For the church architecture to serve the whole human being, it should speak clearly to the senses, intellect, emotions, memory and imagination, aesthetic sensibility, and desire for transcendence or "search for the indefinite" (Schloeder, 1998, p. 48). It needs to speak to people as individuals and as social persons in a community with traditions and responsibilities and as participants in the liturgy (Schloeder, 1998, p. 48). The architecture will contribute to the enrichment of faith that Vatican II sought to impart only when sacred architecture serves the complete human person and persons' social community (Schloeder, 1998, p. 48). 


\subsection{ABSTRACT EXPRESSIVE PAINTINGS}

Based research conducted so far, expressive paintings were made based on how specific keywords used to describe sacred architecture would look in an abstract form. These expressive paintings were done with black and white acrylic paints, palette knives and were done quickly to not overthink the final outcome-this method allowed for a clear range of tones and depth in the paints to come through.
This first painting explores the theme of "grounded" and how churches often evoke this feeling of being heavy and set and the idea of it being an unmovable piece of architecture. The dark paint and the different depths within it capture this dense feeling as the painting looks like it is being weighed down. Coming through the black are bursts of white paint that show that although churches do have this sense of being grounded, ultimately, the church's purpose is to lift spirits closer to God and the heavens. The gradient shown through the tones depict how the closer you are to God spiritually, the lighter you become.

fig8.01 grounded expressive painting 


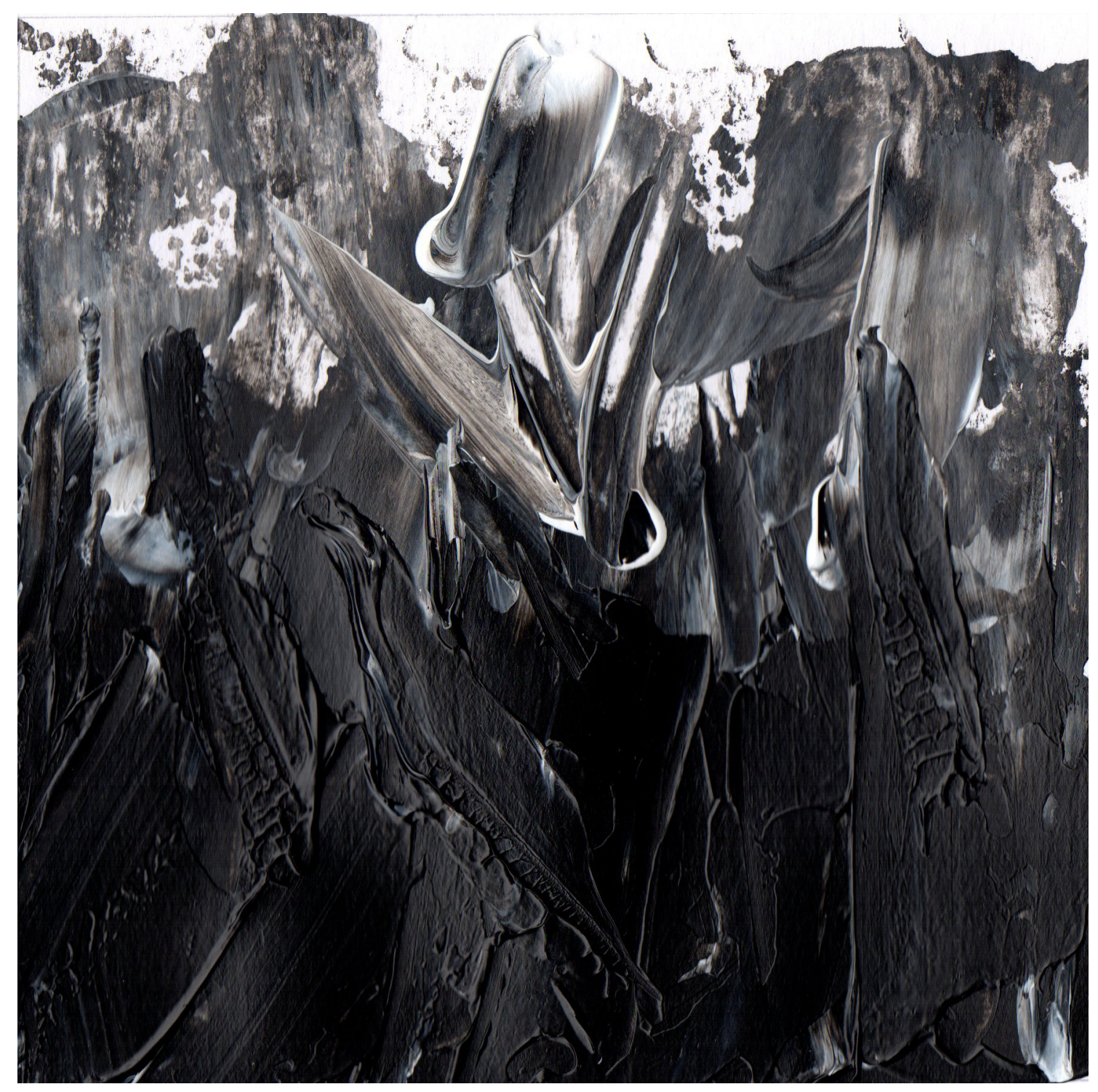


This second painting is based on the idea of intimacy as churches are buildings that are both open and intimate at the same time. The arc in the painting expresses the openness churches bring and can also be seen as arms welcoming to a more intimate experience. This can be seen through the wide-angle these light "arms" occupy, getting smaller to a darker point in the painting's bottom corner. This darker corner signifies the more intimate experience the church offers. Although a church is seen as a public space, its experience is unique and different for all as it is based on the individual itself and their spiritual journey.

fig8.02 intimacy expressive painting 


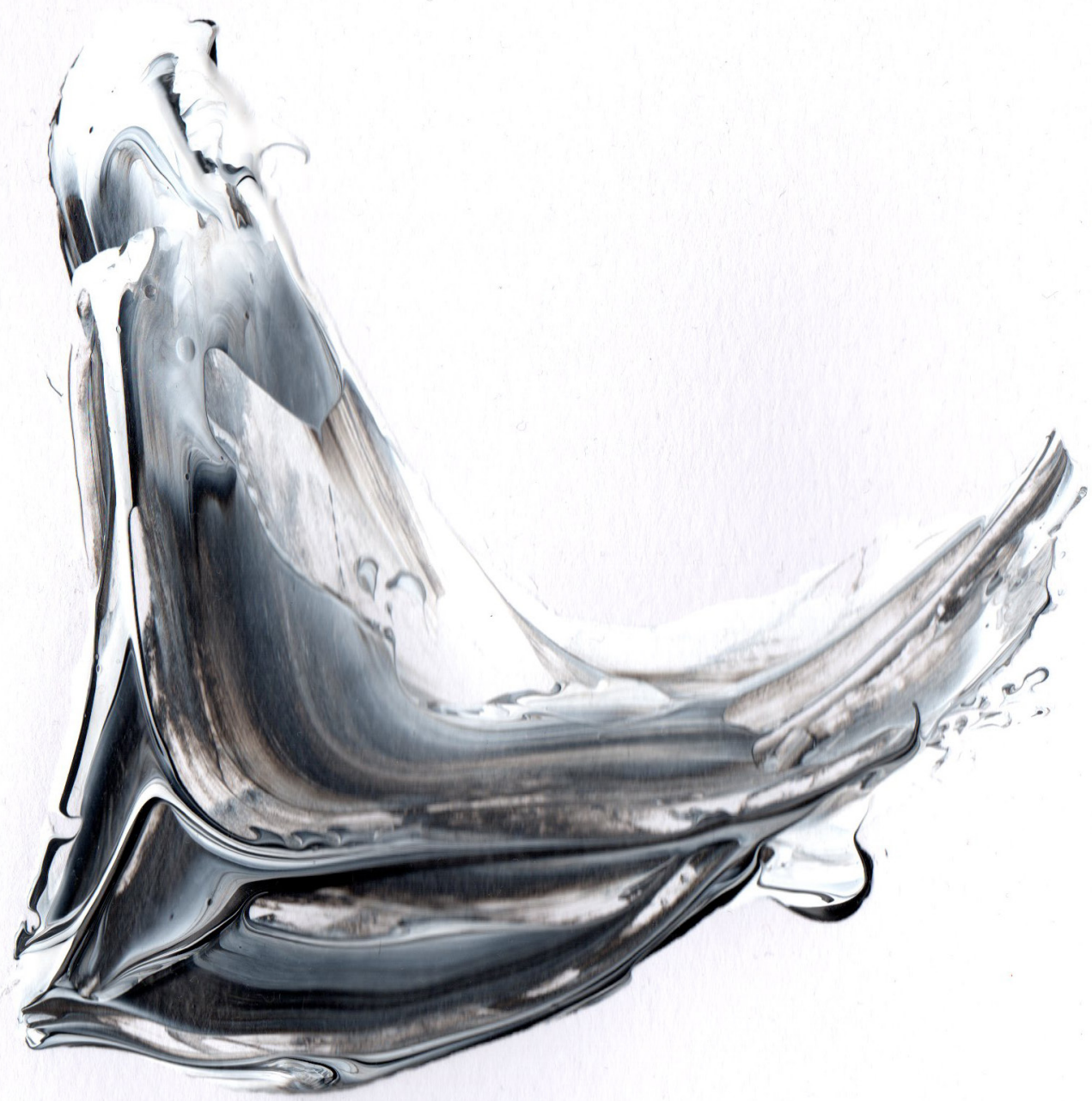


The idea and theme of transcendence is the inspiration behind this third painting. When thinking of transcendence, being out of this world and the feeling of "beyond" comes to mind. In this painting, the notion of transcendence is shown through white paint being predominantly used and coming through the darkness that is the physical and ordinary world. The light use of colour represents a spiritual journey of some sort, that as one progresses in their journey and becomes closer and closer to God, more lightness comes through over time.

fig8.03 transcendence expressive painting 


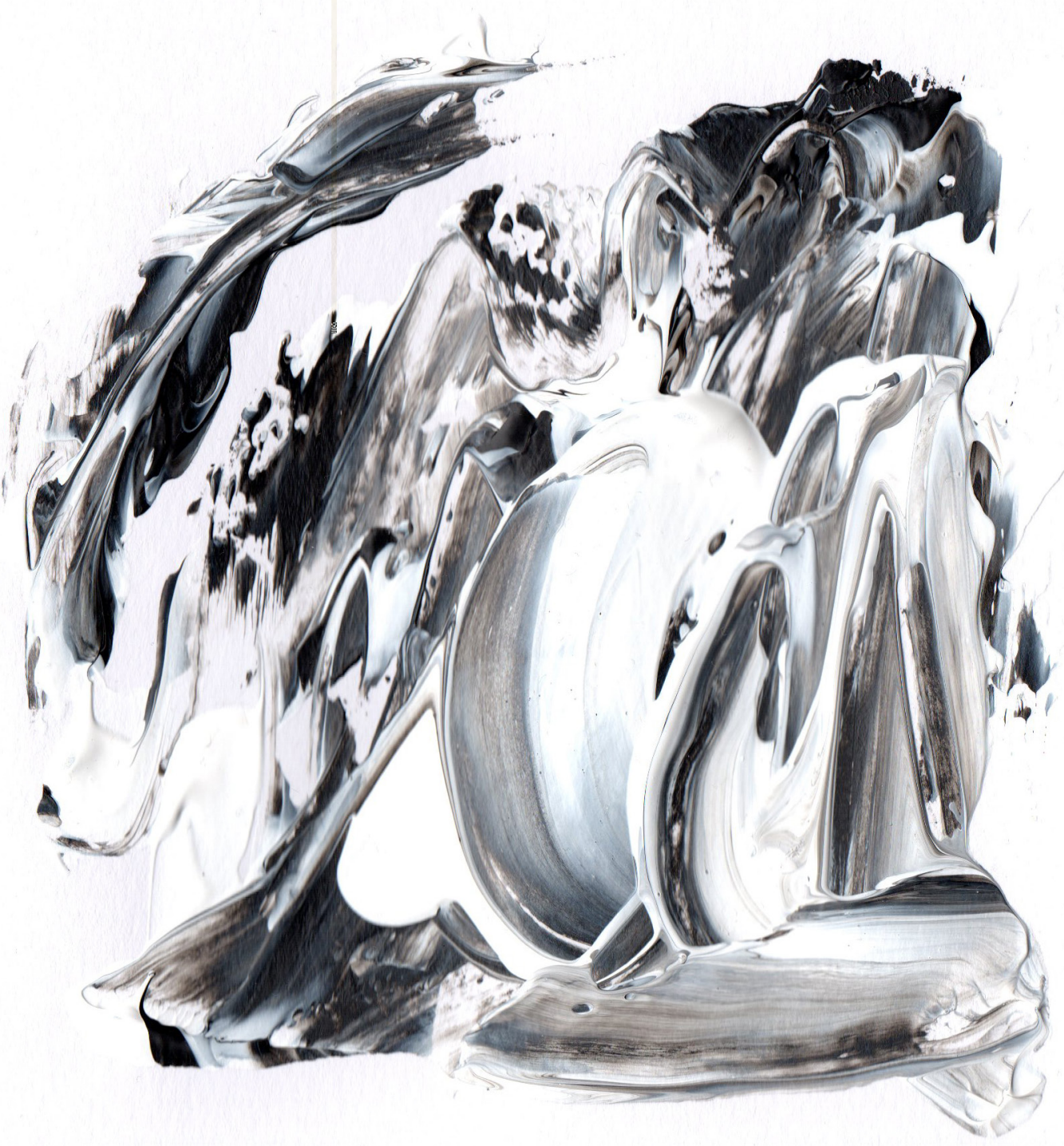


Finally, to conclude the series of expressive paintings done for design exploration, this final painting portrays the notion of a church being a physical bridge between the people and God. The dark paint at the bottom corner represents the people and how they are grounded on Earth, and the light paint at the top corner represents the higher power and the spiritual realm. These two worlds merging in the middle symbolises sacred architecture and how the buildings are used bring the people and God to each other.

fig8.04 bridge expressive painting 


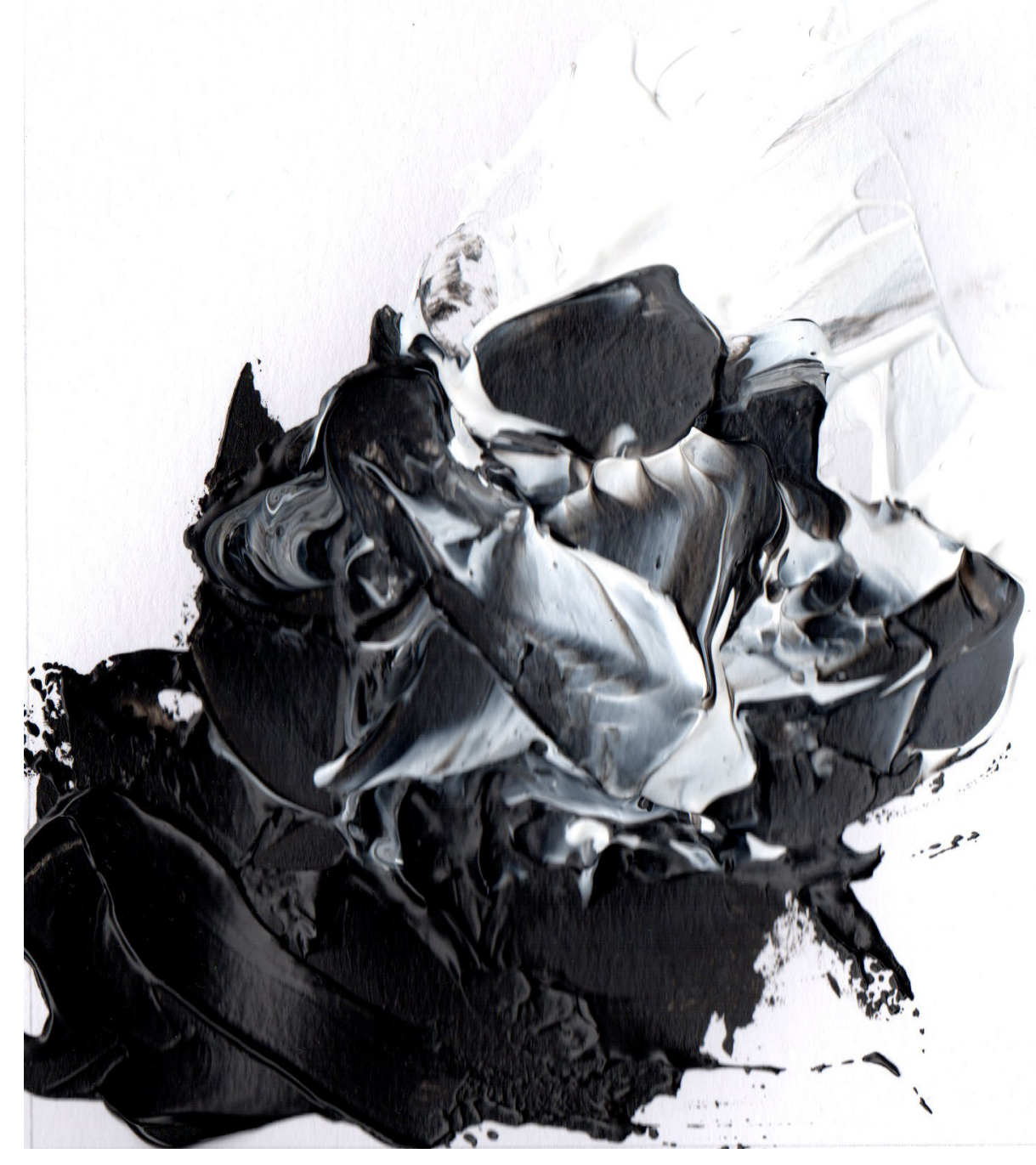




\subsection{RESEARCH ON CHURCH SPACES}

In the holy liturgy, each person, cleric and lay, have a proper place and plays a particular part as the church operates in a hierarchically ordered body to worship as a community (Schloeder, 1998, p. 50). The liturgy is the core of the church's life, both corporately and in the life of each member of the community. Every aspect of the Cathedral design in this thesis that affects the liturgy demands the most significant considerations to create an environment that can fully contribute to the celebration.

The Cathedral design needs to consider both the communal and hierarchical aspects of the congregation (Schloeder, 1998, p. 51). As there are two forms of participants in the liturgy - the clergy and the laity - certain matters reserved for the clergy and others assigned to the laity (Schloeder, 1998, p. 51). The church teaches that both types of participants are integral to the church's function; therefore, there is a need for design sensitivity to ensure expressing the importance of one to neglect the value of the other is avoided (Schloeder, 1998, p. 51). The sanctuary and nave's liturgical requirements must also take precedence over every other architectural consideration as the liturgy is the core of every aspect of the Church (Schloeder, 1998, p. 51).

The sanctuary is the most critical and holiest space in the church. A division between the sanctuary and the nave is essential in the building. It reflects the differentiation between the roles of the two types of participants in the liturgy the clergy and the laity (Schloeder, 1998, p. 54). The hierarchic separation of the sacred and the profane and the procession from the profane (the world) to the sacred (the altar, being heaven) is found from Christian antiquity onward (Schloeder, 1998, p. 54).

Expressions of this separation have been deeply rooted in almost every ancient culture and religion (Schloeder, 1998, p. 54). By the end of the third century, when the basilica plan had been established, it expressed a transition from the profane to the sacred via an entry courtyard, a narthex, and a longitudinal nave leading to the sanctuary (Schloeder, 1998, p. 54). This arrangement of the basilica plan is derived from the existing Mediterranean culture, Jewish synagogues, pagan temples, and law courts, during an age familiar with the ideas of both sacrality and profanity (Schloeder, 1998, p. 54).

Apart from the Eucharist, baptism is another sacrament in the Catholic Church that demands the most architectural consideration (Schloeder, 1998, p. 111). Baptism is the first and fundamental sacrament in the church; thus, the baptistery should be an important space and a focal point in the Church (Schloeder, 1998, p. 111). The baptismal font and the baptistery have always been important iconographic elements in the church. Even though there has never been any uniformity in their design, decoration, or placement, the font and baptistery's form, location, and decoration are used to explain and symbolise the meaning of baptism (Schloeder, 1998, p. 111). 
As baptism is the entrance into the church and signifies the beginning of the person's spiritual journey, baptisteries were often placed near the Church's entrance (Schloeder, 1998, p. 112). The baptistery's placement at the entry to the church is a very historical and poignant symbol of entering the church as it was only after the baptism that the newcomers would be allowed into the church's nave and initiated into the sacred mysteries (Schloeder, 1998, p. 112).

In recent times, the baptistery has been the subject of architectural experimentation. Exploring the baptism idea of initiation and entrance into the church community has been done recently by bringing the baptismal font into the narthex or designing a separate and distinct chapel attached to the west end of the church (Schloeder, 1998, p. 119). However, some liturgists argue that the font could be placed at the church's east end near the sanctuary, as long as it was in a clearly defined area seen independent from the sanctuary. They believed a closer relationship between and the Eucharist and favouring more communal participation was important (Schloeder, 1998, p. 119). Others insist that the baptistery should be at the church's entrance as this is how it has been traditionally for many centuries as baptism has primarily been understood as the entry and initiation into the Church (Schloeder, 1998, p. 119). The notion of baptismal entering seen "as through a door" is both ancient and essential in establishing the baptistery's location (Schloeder, 1998, p. 121).
Reconciliation is the other sacrament that demands architectural consideration apart from the Eucharist and baptism. To preserve the dignity of the sacrament and the repentant's privacy, a separate room or "reconciliation chapel" is encouraged to be incorporated into new buildings and in remodelling projects (Schloeder, 1998, p. 125). These confessionals can be placed suitably anywhere in the church, provided they are in an open area such as the nave or narthex (Schloeder, 1998, p. 126). Many suggest placing the confessionals in the narthex/entry hall or even near the baptistery to place the sacrament in its symbolic and traditional context (Schloeder, 1998, p. 126). Othersalso suggest placing the confessionals in the narthex as it was not just the entrance to the church but also a space reserved for those not admitted to the sacraments (pagans, penitents, unreconciled) (Schloeder, 1998, p. 126). By traditionally keeping the confessionals and the baptistery as separate and far away from the sanctuary and the Eucharist as possible, it follows the notion of the church forbidding reception of the Eucharist by those conscious of grave sin (Schloeder, 1998, p. 126). 


\subsection{BUBBLE DIAGRAMS}

The different areas essential in a Cathedral were listed, and an adjacency matrix was used to identify the relationships between the various spaces. This adjacency matrix was used to determine how close the spaces should be to each other based on their function and use. A bubble diagram was then produced based on the findings to visually demonstrate the relationships between the functional areas of the Cathedral to help develop an architectural plan.

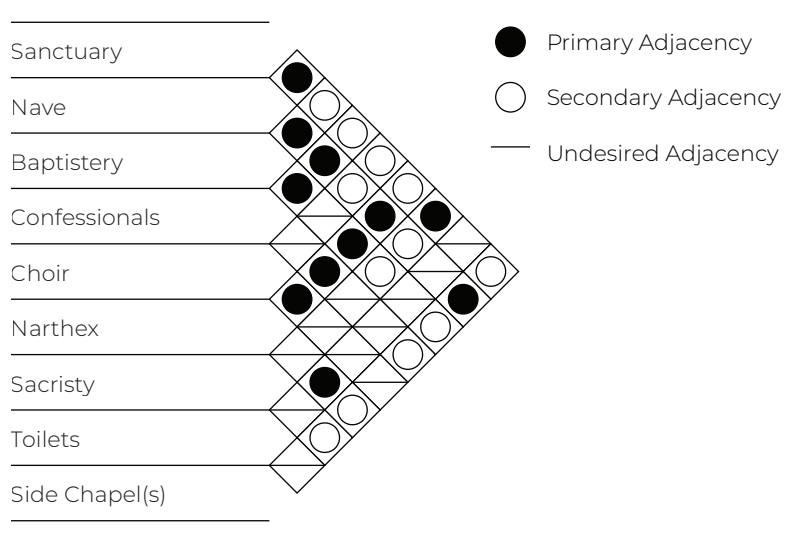

fig8.05 adjacency matrix of spaces in cathedral

fig8.06 bubble diagram of spaces in cathedral

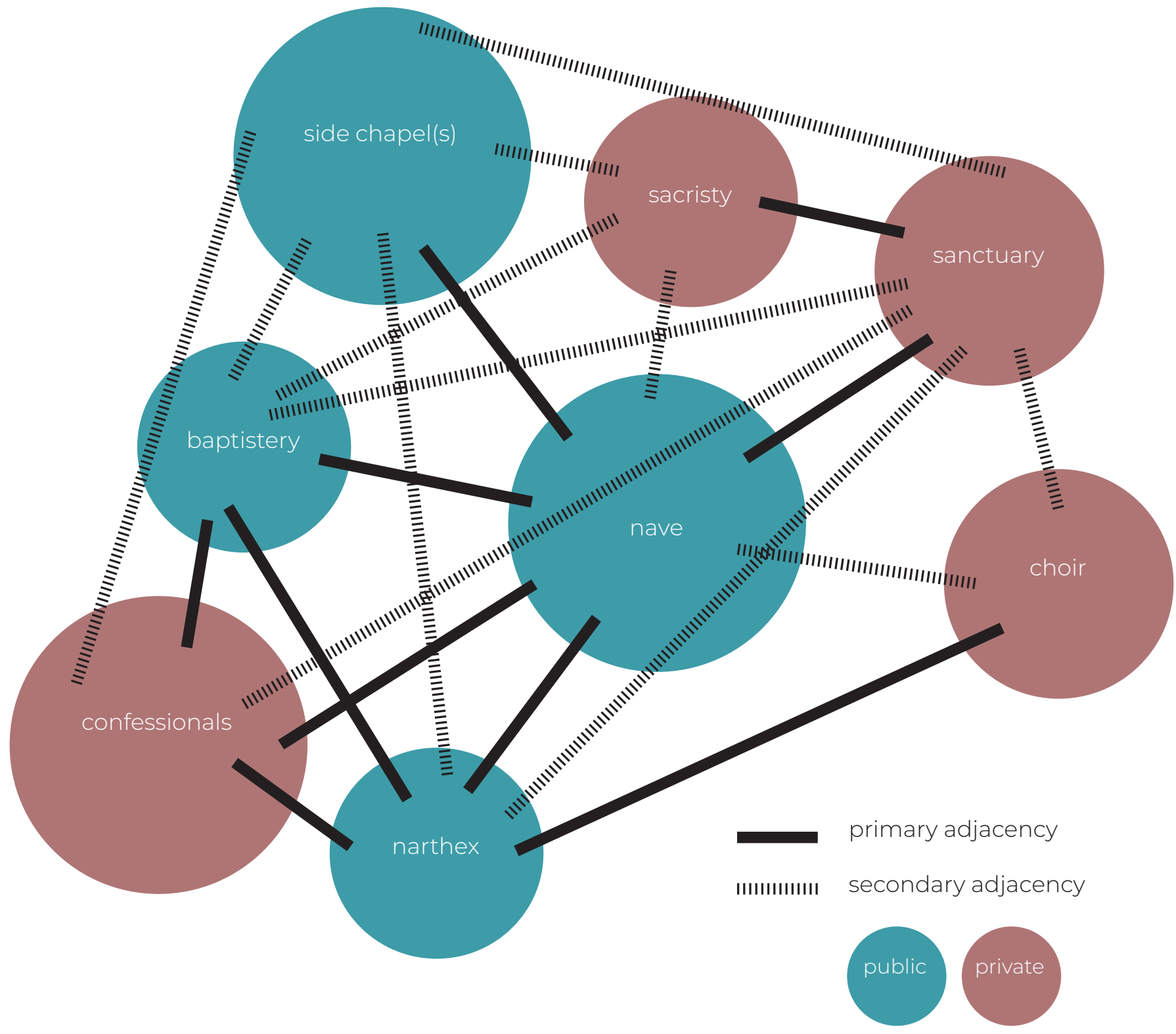



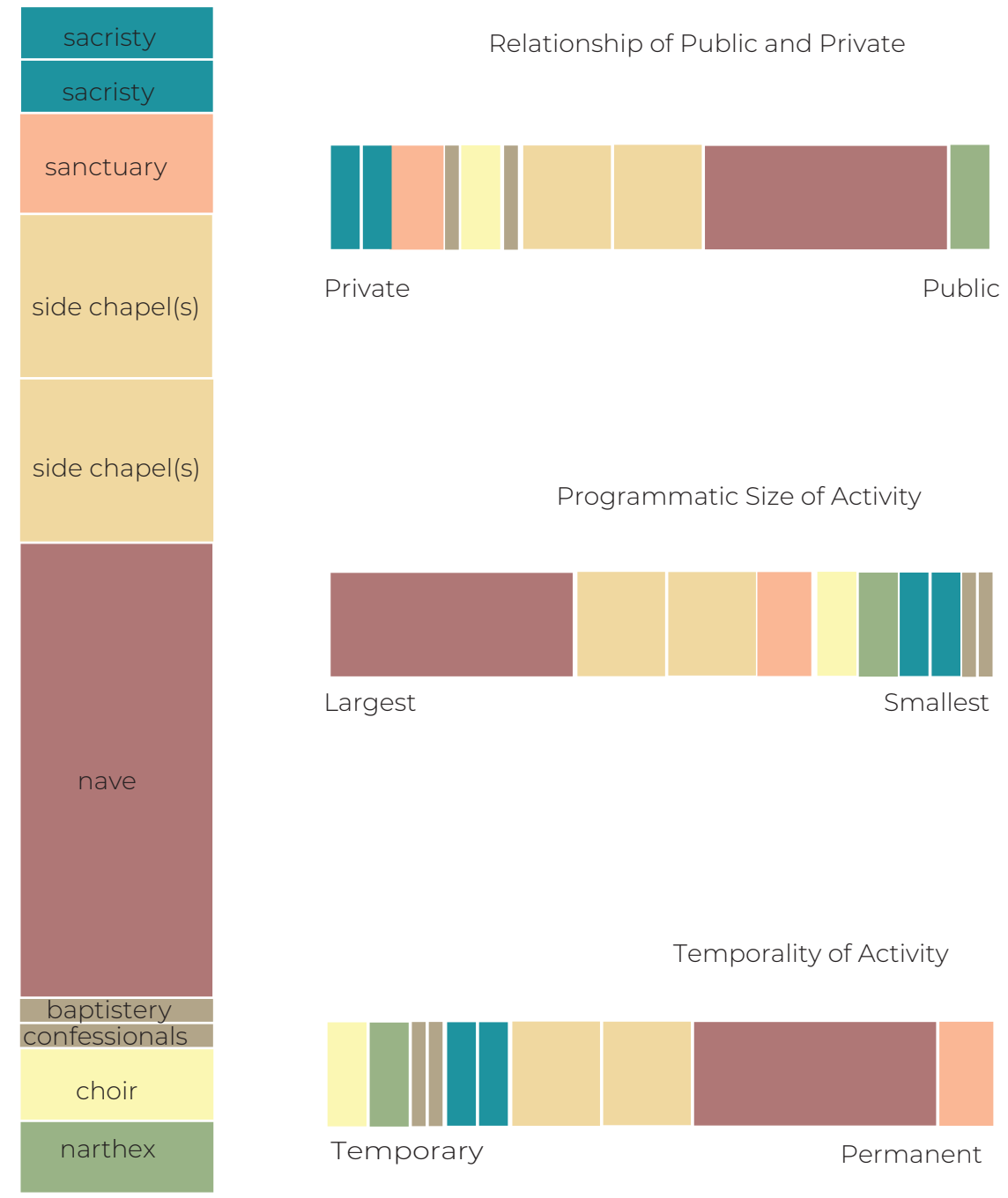

Programmatic Size of Activity

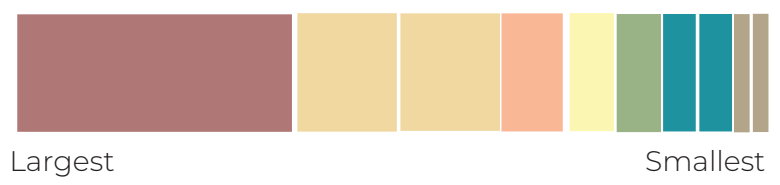

Temporality of Activity

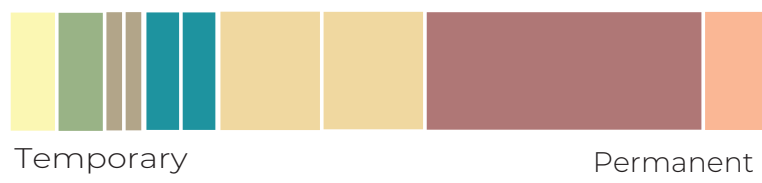

fig8.07 diagram showing analysis of relationship of spaces

Further analysis of the different spaces that are intended to be in the Cathedral was done. This analysis primarily focused on the sizes and uses of the areas relative to each other. It also focused on laying out these spaces in a layout based not only on the research found earlier but also on how different types of occupants would utilize the building. As discussed earlier, the baptistery and confessionals are traditionally located at the front end of the building and closer to the entrance.
This is because these spaces are where one would cleanse themselves of their sins - through the sacrament of baptism and cleanse one from the original sin everyone was born with, and through the sacrament of reconciliation where one can ask for forgiveness for the recent sins committed. The two spaces are conventionally kept as far away from the sanctuary as possible as the sanctuary is the most sacred area in the church, and it was believed that no one should be near it if they are not clean from sins. These two spaces are usually at the front of the building near the entrance as they are the path and an entrance to a cleaner soul and journey. 
The bubble diagram and analysis demonstrate an illustrated floor plan that portrays where each space could occupy and allows an architectural plan to be developed. As previously mentioned, the diagram also shows how three typical types of occupants of the Cathedral would usually operate in the building. The red line shows how the priest or bishop would occupy the space, having access to virtually all the building areas, especially the most private and sacred spaces, the sanctuary and sacristy. The blue line represents a typical mass/church attendee, arriving from the entrance and solely staying at the Cathedral's nave and only going up to the front near the sanctuary to receive communion. The grey line shows how a general public member might operate inside the Cathedral when the building is open for visitors during non-mass times. It shows how this type of person might walk around the whole building and exploring the different spaces while also respecting the boundaries set for the sanctuary, sacristy, and other private areas. 


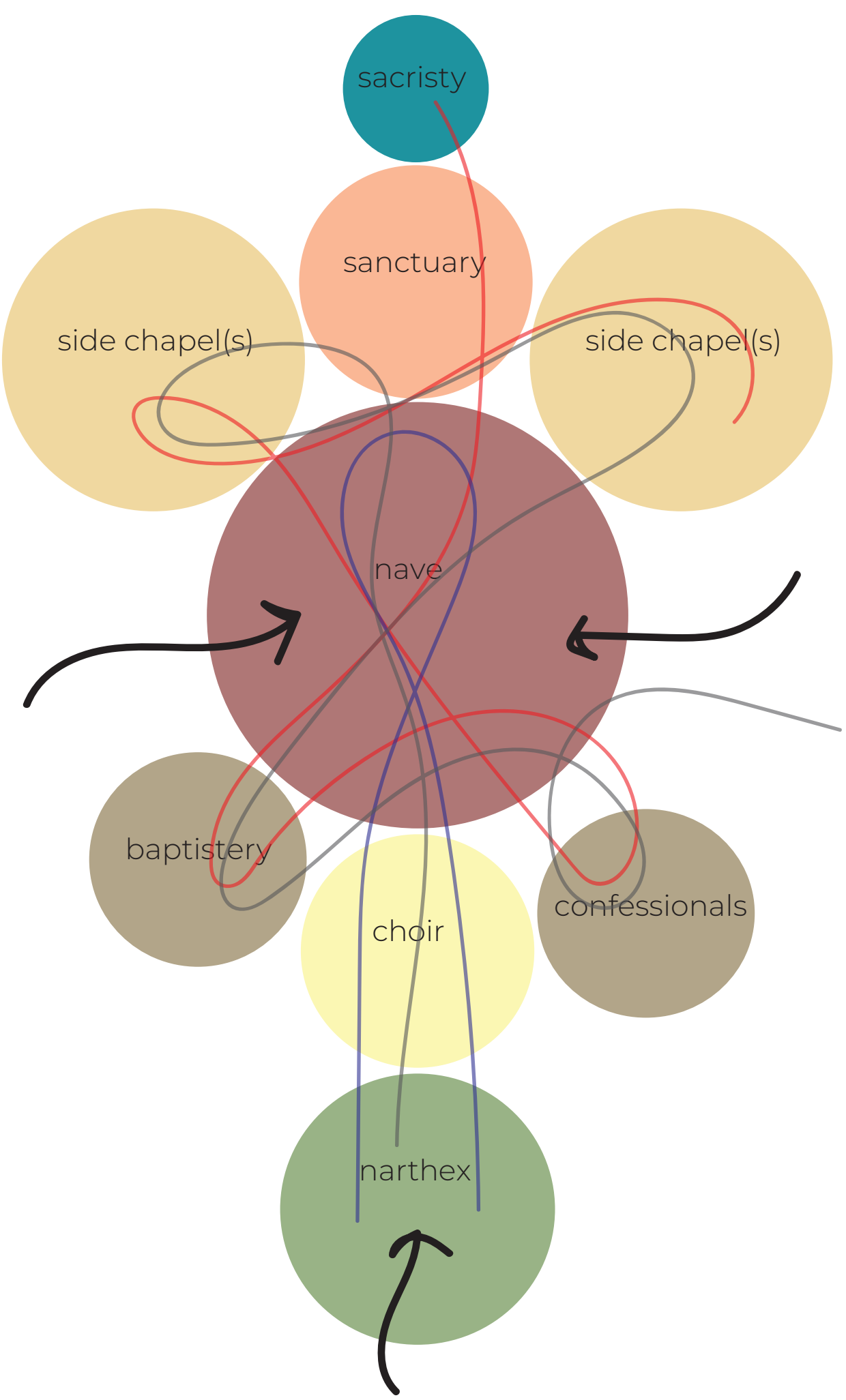

- Clergy

_ Typical Mass Attendee

_ Tourist/General Public

fig8.08 diagram showing relationship of spaces and types of interaction within 


\subsection{INTERNAL RECTANGLE DIAGRAMS}

It is challenging to completely separate contemporary Church forms from historical precedents as certain forms have come to belinked to specific meanings and ideas (Schloeder, 1998, p. 227). When these ideas are ignored, there is an opportunity for the symbolic aspect of the architecture to send conflicting messages and be "speaking" of something unintended (Schloeder, 1998, p. 227). As specific ideas have been traditionally associated with certain words, symbols, and forms, it is crucial to work within these vocabularies not to follow the modern tendency to ignore the historical architectural forms associated with church buildings (Schloeder, 1998, p. 227). By not following tradition and constructing an entirely new language or iconography; instead, there is a possibility that this language will not be understood and will not be meaningful (Schloeder, 1998, p. 227).

Churches need to be both modern and traditional, and this implies that new church architecture should be rooted to some degree in historical architectural precedent (Schloeder, 1998, p. 226). Regarding ordering of the spaces in the church, the guidelines given during Vatican II was: "in order that sound tradition be retained, and yet the way remain open to legitimate progress... care must be taken that any new forms adopted should in some way grow organically from forms already existing" (Schloeder, 1998 , p. 238). The church demands that the whole assembly be reflected in the sacred building's general plan (Schloeder, 1998, p. 238). They request that a hierarchical arrangement be expressed in the church's spatial configurations and should also "form a complete and organic unity" that clearly expresses the unity of the holy people (Schloeder, 1998, p. 238). An arrangement that fully understands this begins to address the iconographic concern of the architecture representing the church as the bridge between the body of Christ and the people of God (Schloeder, 1998, p. 238). It is important to have building forms define the separate functional volumeswithin as it is in keeping with the church's guidelines (Schloeder, 1998, p. 241). As previously discussed, it is understood that the baptistery should be a clearly defined place reserved for the sacrament. The sanctuary should also be clearly distinguished from the rest of the church to express its hierarchical importance from the rest of the spaces (Schloeder, 1998, p. 247). 


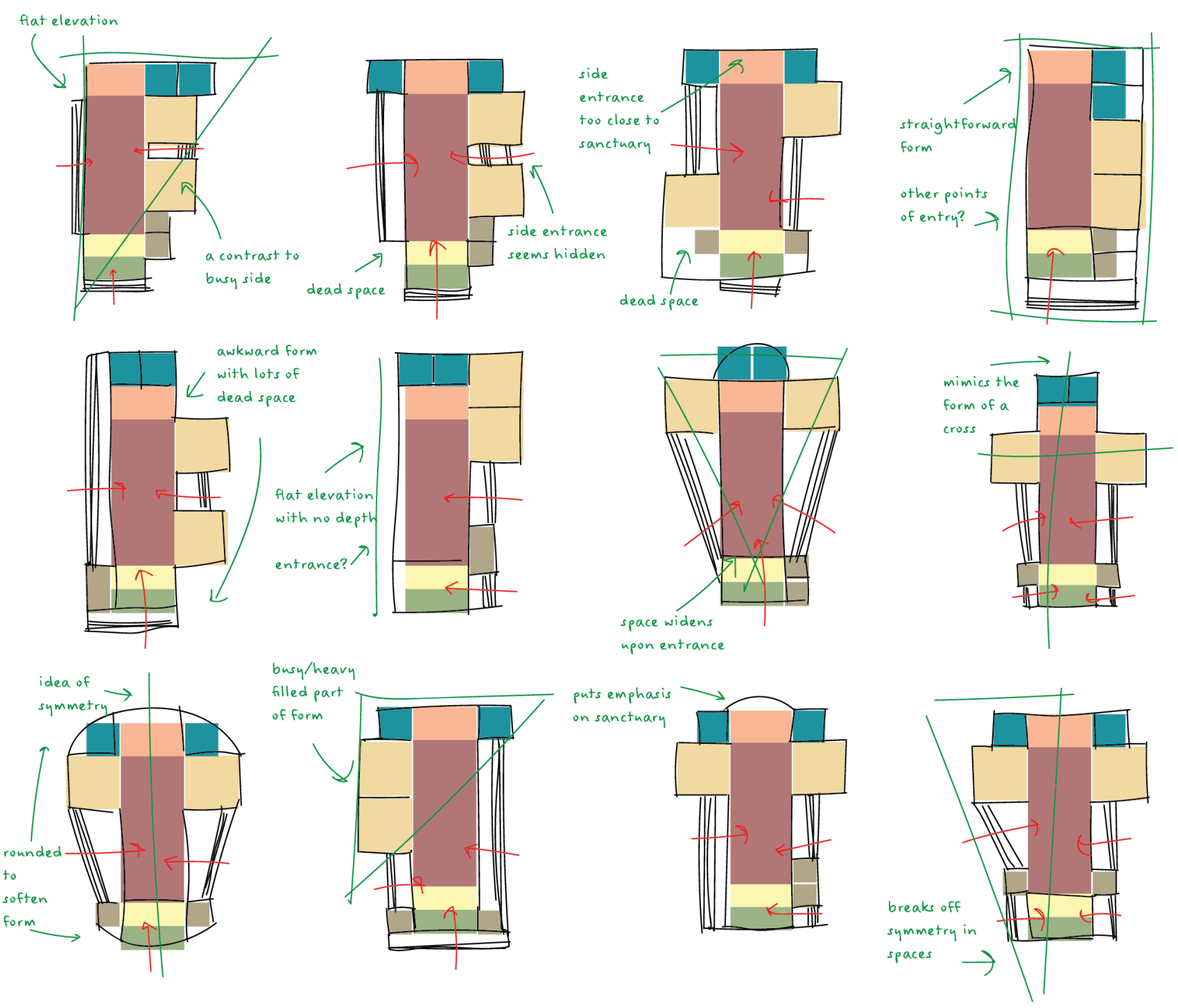

fig8.09 sketches of different possible spatial configurations

Based on the analyses and diagrams completed, exploring different floor plan configurations was done. Via architectural massing, it becomes easier to start visualising how the research and analyses conducted can be seen architecturally. The different arrangements and planning/ drawing on top of them as if they were architectural plans helps determine which designs and layouts were more successful than the others while being mindful of the findings found in previous research. This massing exercise was beneficial as it allowed us to see the research in a building form of some sort. It became easier to visualise how the different spaces could start to form a piece of architecture.
This exercise experimented with moving the different spaces around to produce different configurations of possible floor plans for the Cathedral. Moving the side chapels around the building, and the baptistery and confessionals were explored in this exercise to understand how the different placement of these would affect the building's form and how people would operate within it. Through research and experimenting with layout configurations, the traditional layout is found to be the most successful. Keeping it as simple and straightforward as possible is effective for a reason with the users of the space. It makes it easier to understand the architecture, especially in an environment like a Cathedral where the focus should be on spirituality and not how one should navigate the space. 


\subsection{OVERLAY OF SKETCHES}

Based on the expressive paintings earlier in the chapter, sketches were overlayed on top based on the different shapes and forms produced in the paintings. These conceptual sketches drawn produced ideas on what the design could be like or what it could incorporate. By doing this exercise, we start to visualise architectural spaces based on the research found so far.
This first drawing comes from the "grounded" painting. The sharp angles produced in the painting inspired this building elevation idea where clean geometric lines create the building form to achieve a modern look and feel to the Cathedral. Although a simple design idea and sketch, this gives an idea of where the design might be headed.

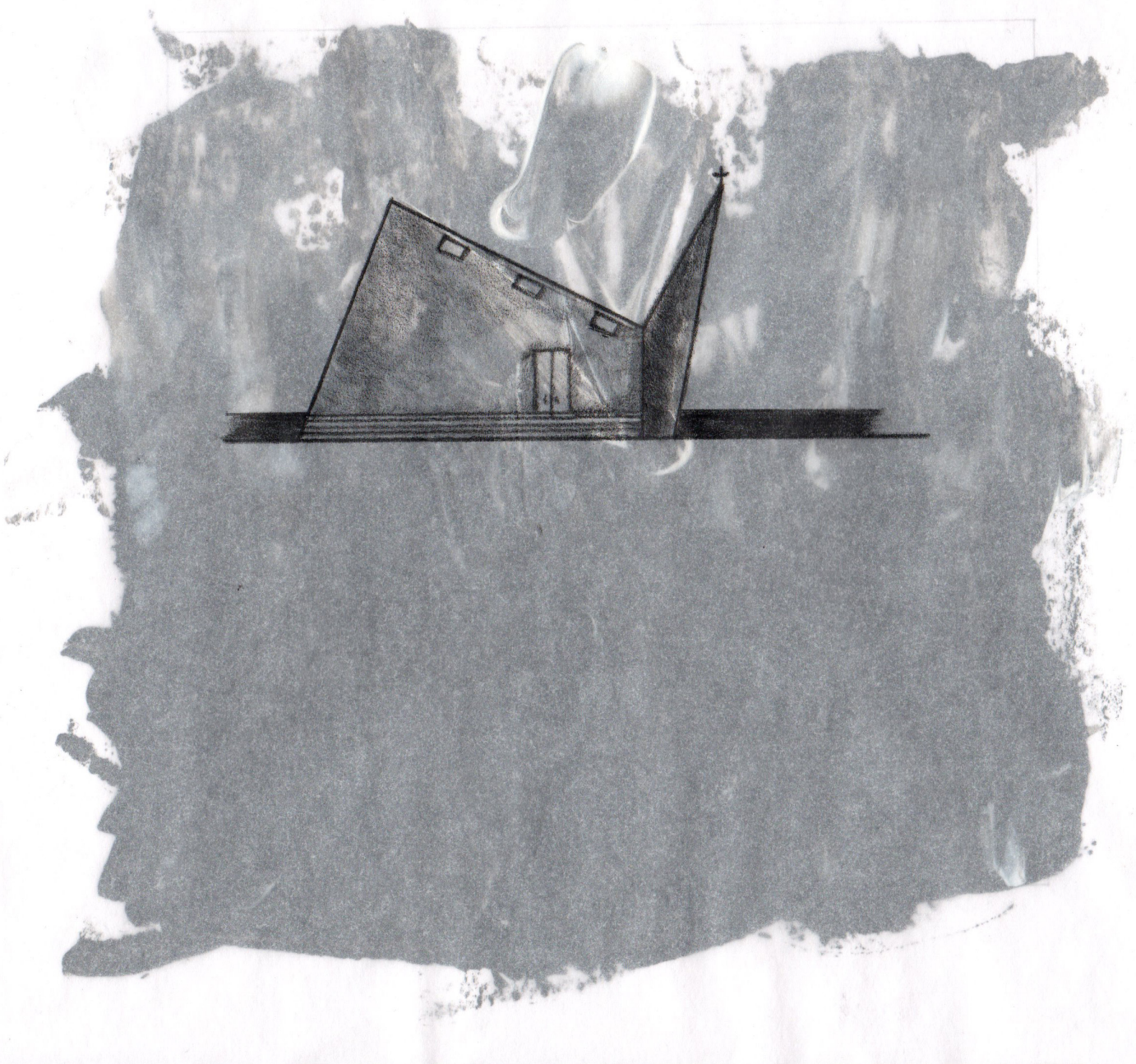




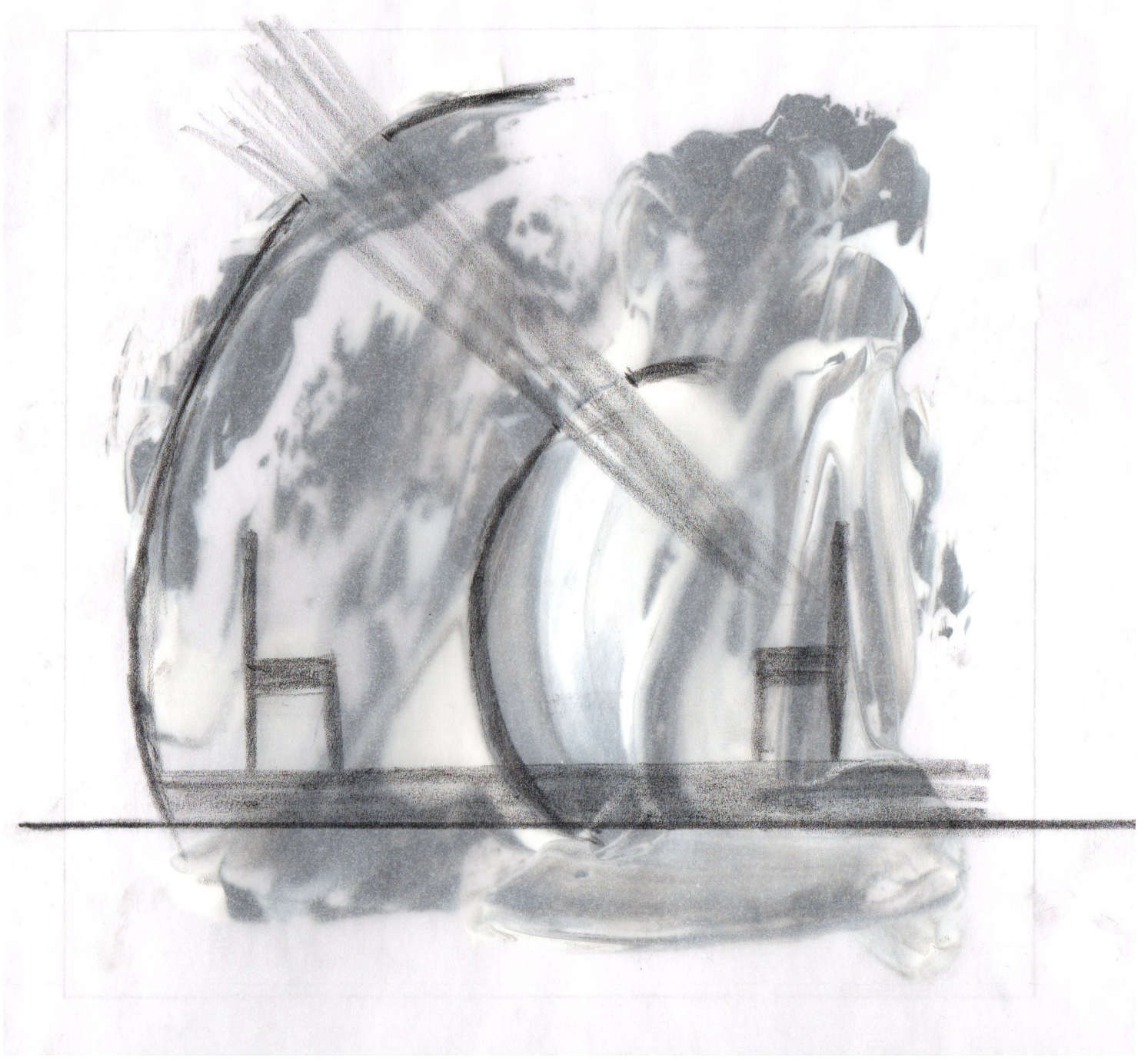

This second conceptual idea is from the painting inspired by transcendence. fig8.11 sketch of confessional and the idea of privacy and forgiveness

The loose waves formed in this painting created this idea of protection and privacy found in a confessional. The idea of being able to confess confidentially and having this beam of light on the penitent to show God's presence in the process of forgiveness is an architectural and spatial quality that could be included in the design. 


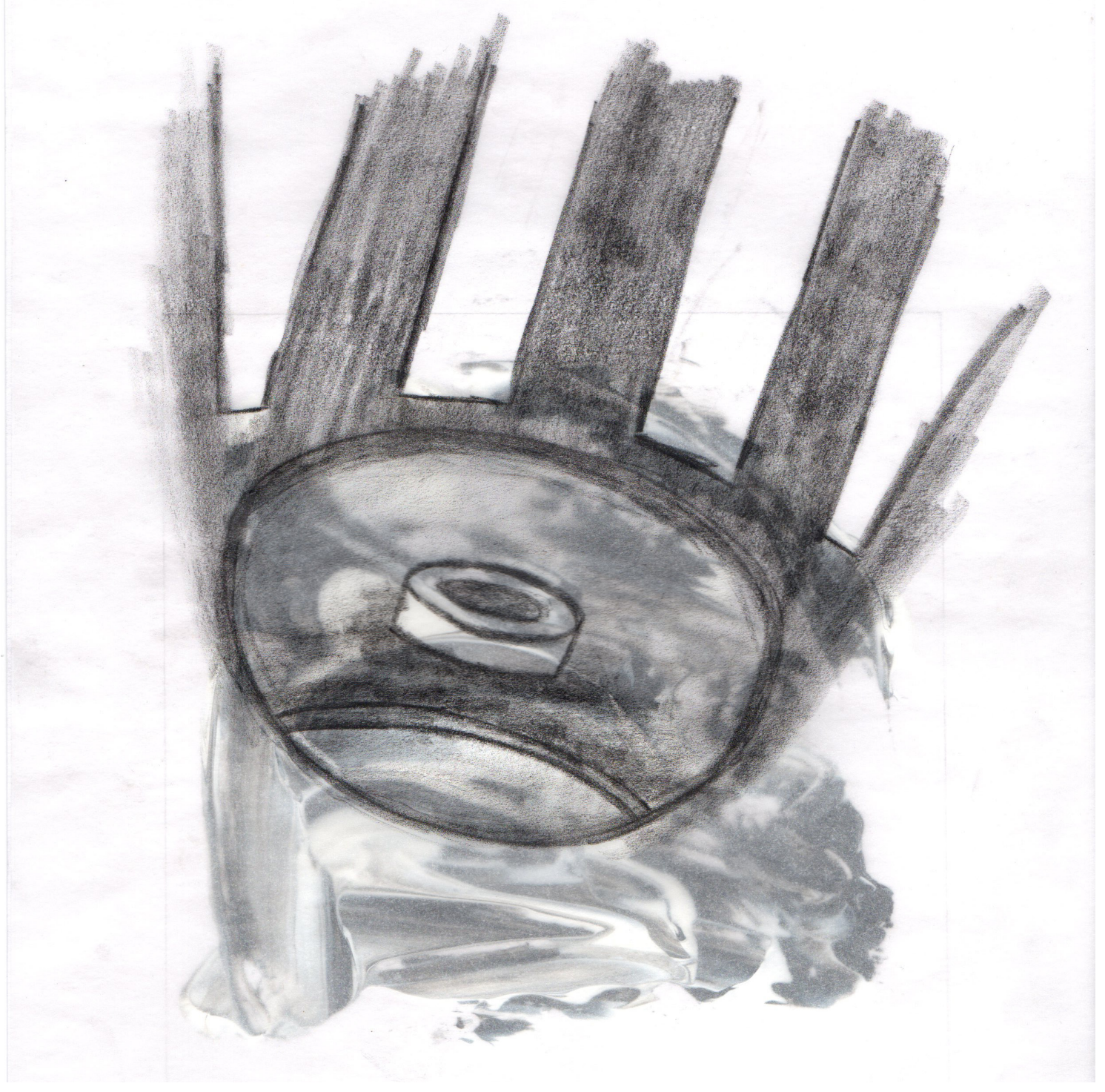

This sketch is also based on the "transcendence" painting, and conceptually illustrates the baptistery idea. A circular baptismal font in the centre of a circular baptistery room is surrounded by lots of windows to provide natural light. This sketch shows how the idea behind this is to design a space that provides a positive and unique experience, separate from the Cathedral experience itself, based on the architectural space and qualities designed. 


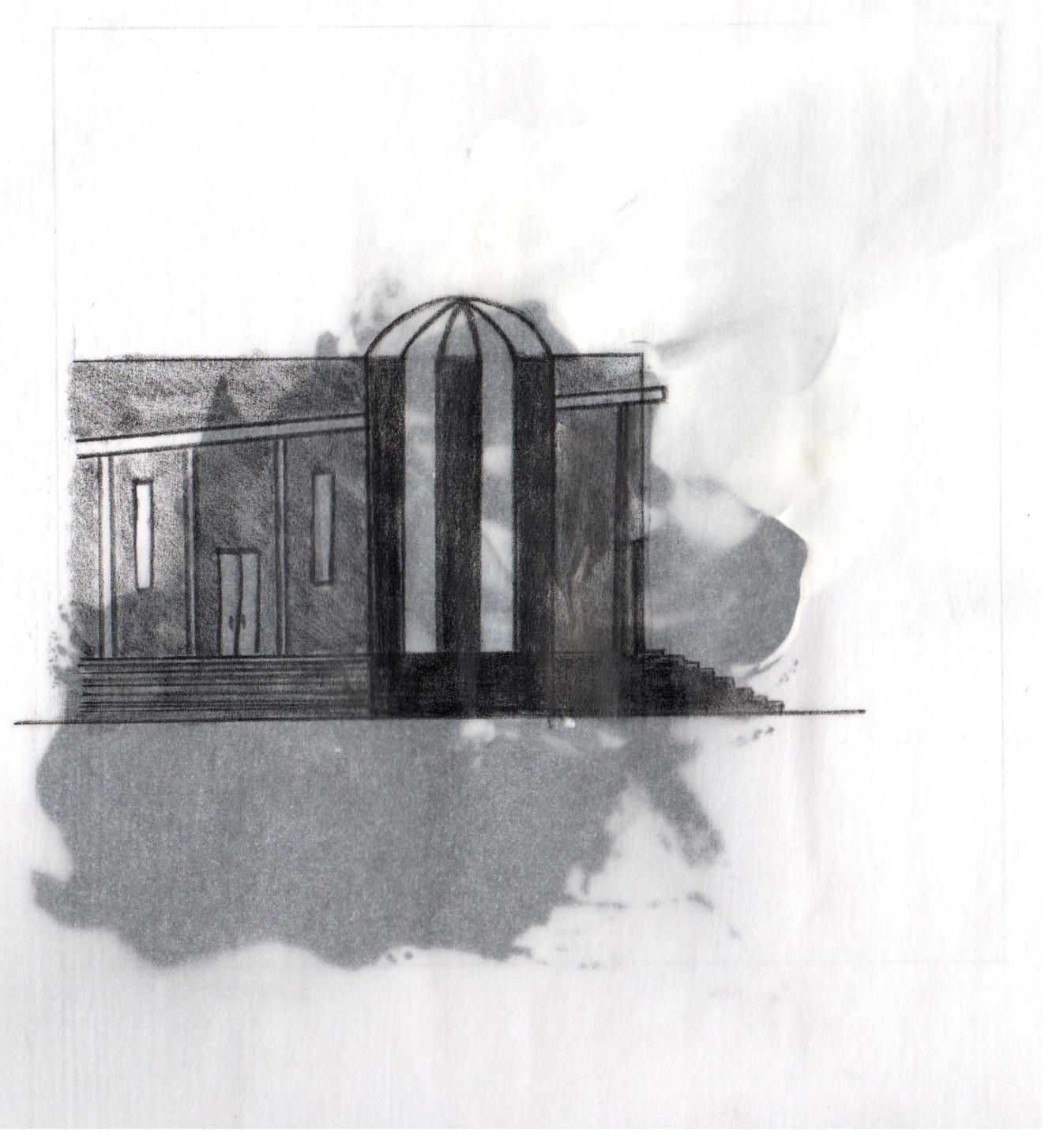

This sketch is overlayed on top of the fig8.13 sketch of partial elevation showing a glass dome "bridge" painting and shows the idea of a modern glass dome in the Cathedral. This concept comes from the idea of paying homage to the old dome of the previous Cathedral and placing it in a new location within the building. This drawing accompanies the previous drawing as the dome is situated above the circular walls of the baptistery. The main idea behind this is to provide as much light as possible to shine down on the person as they are getting baptised to signify that God is present with them. 


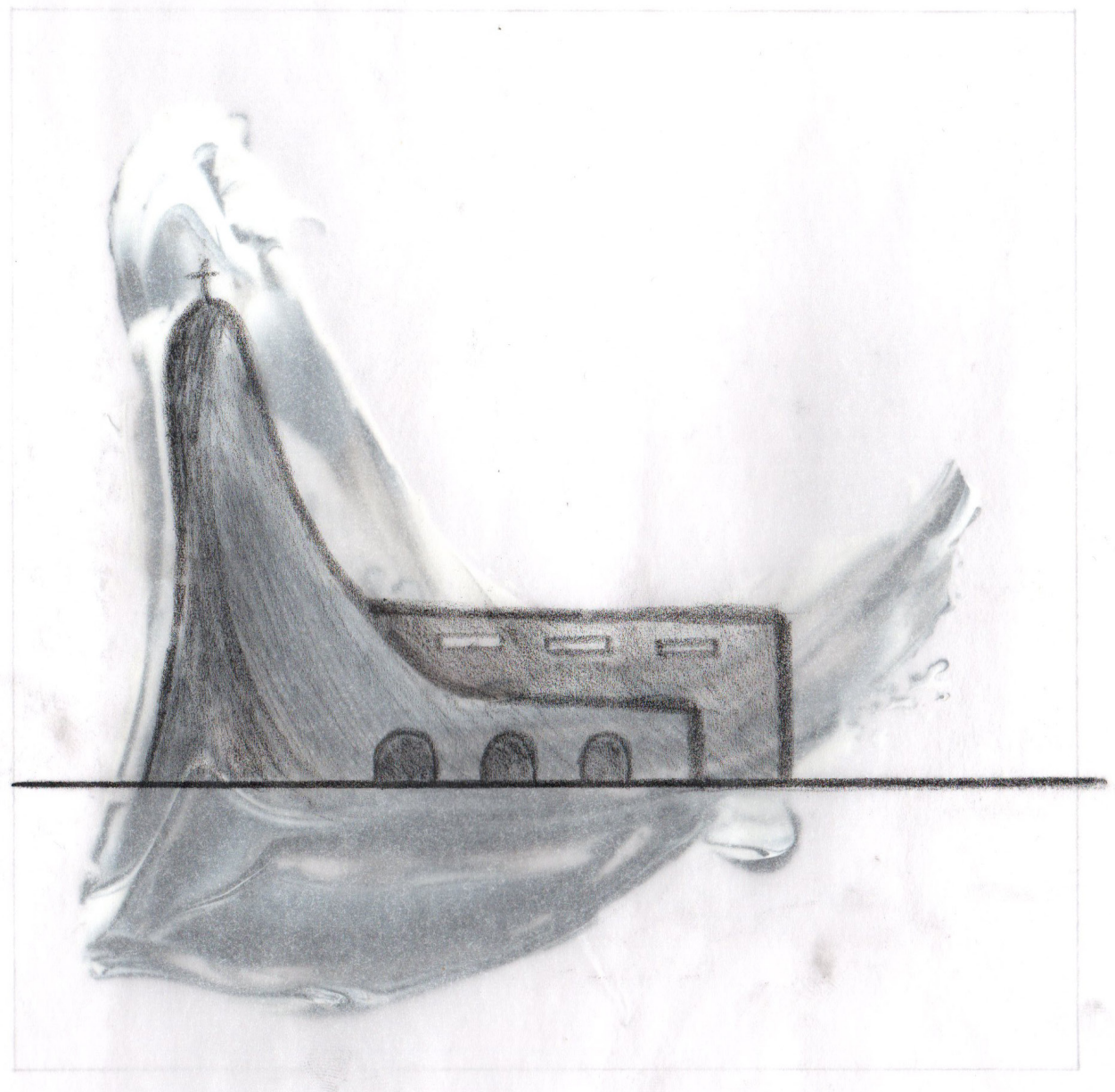

Based on the smooth curve created in the painting based on intimacy, this fig8.14 sketch of spire adopting an organic form and towering over the nave behind it sketch overlayed on top illustrates an idea for a building form and elevation for the proposed cathedral design. This idea intends to have an organic feel to the buildings based on the spire's curves. This sketch starts to see ideas found from research put into architectural and spatial forms, such as the nave in this drawing. 


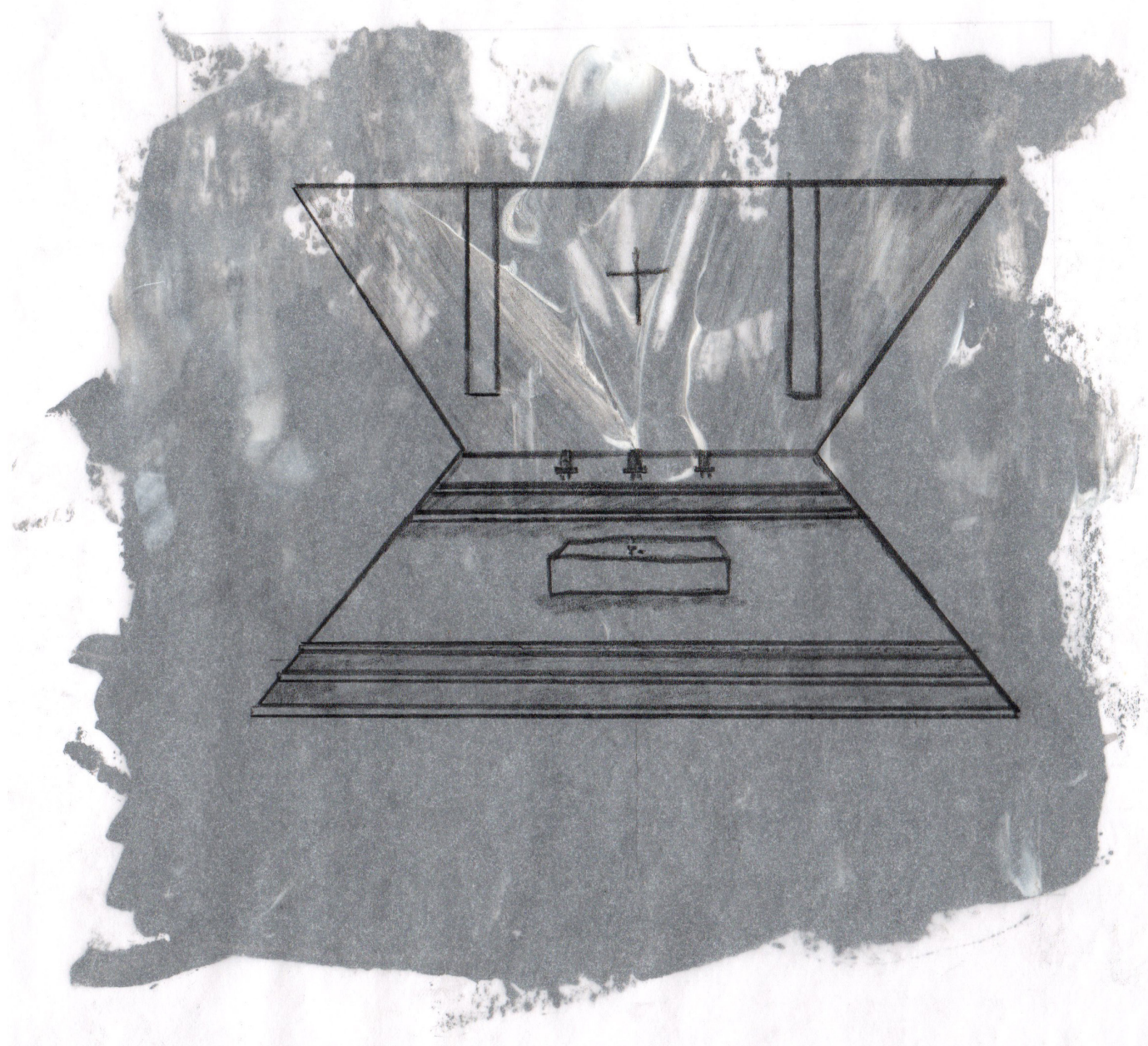

Like the other "grounded"drawing, thiswas also inspired by the sharp angles created

fig8.15 sketch showing the different levels in the sanctuary, emphasising the idea of hierarchy within the building in the painting. This sketch illustrates the notion of hierarchy within the church and explores how this could be achieved in the design. This sketch places the idea of hierarchy in the church's sanctuary area, where steps both lead up to the altar and the bishop's throne to show the bishop's higher status and importance over the people. 


\subsection{DESIGN CONCEPTS}

Considering the successful internal layout planning, putting the research and experimentation together into different architectural concepts was completed. These concepts aimed to produce architectural sketches of ideas on how the planning could formalise into a proper architectural form. Most of these concepts were brought forward and inspired by the earlier spatial sketches overlayed on top of paintings to develop those quick sketches further and build concrete concepts with meaning and a narrative. In these conceptual drawings, the diagrammatic planning of layouts done before is turned into actual rooms with architectural qualities to showcase how the Cathedral design is starting to develop and come to life.
This first concept takes on a traditional gabled look for a Cathedral that also included a spire. This concept's simple plan is focused on ensuring the spaces within the design follow the research and planning done in the previous section. A problem faced with having the focus on the research and planning done is that the architectural form has resulted in not being experimental enough and producing a conceptual design that is overly simple. It was planned to have a traditional front main entrance, with stairs leading up to the doors to evoke a feeling of grandeur for the occupant to enter and access this design. A side entrance on the west side was also planned; however, providing a side entrance on only one side of the building unknowingly introduces problems of lack of access points to the design. Ways to somewhat modernise this traditional gabled design were done by opening the roof up with multiple skylights and placing numerous windows of various sizes to allow an abundance of natural light into the space.

fig8.16 concept 1 sketch 

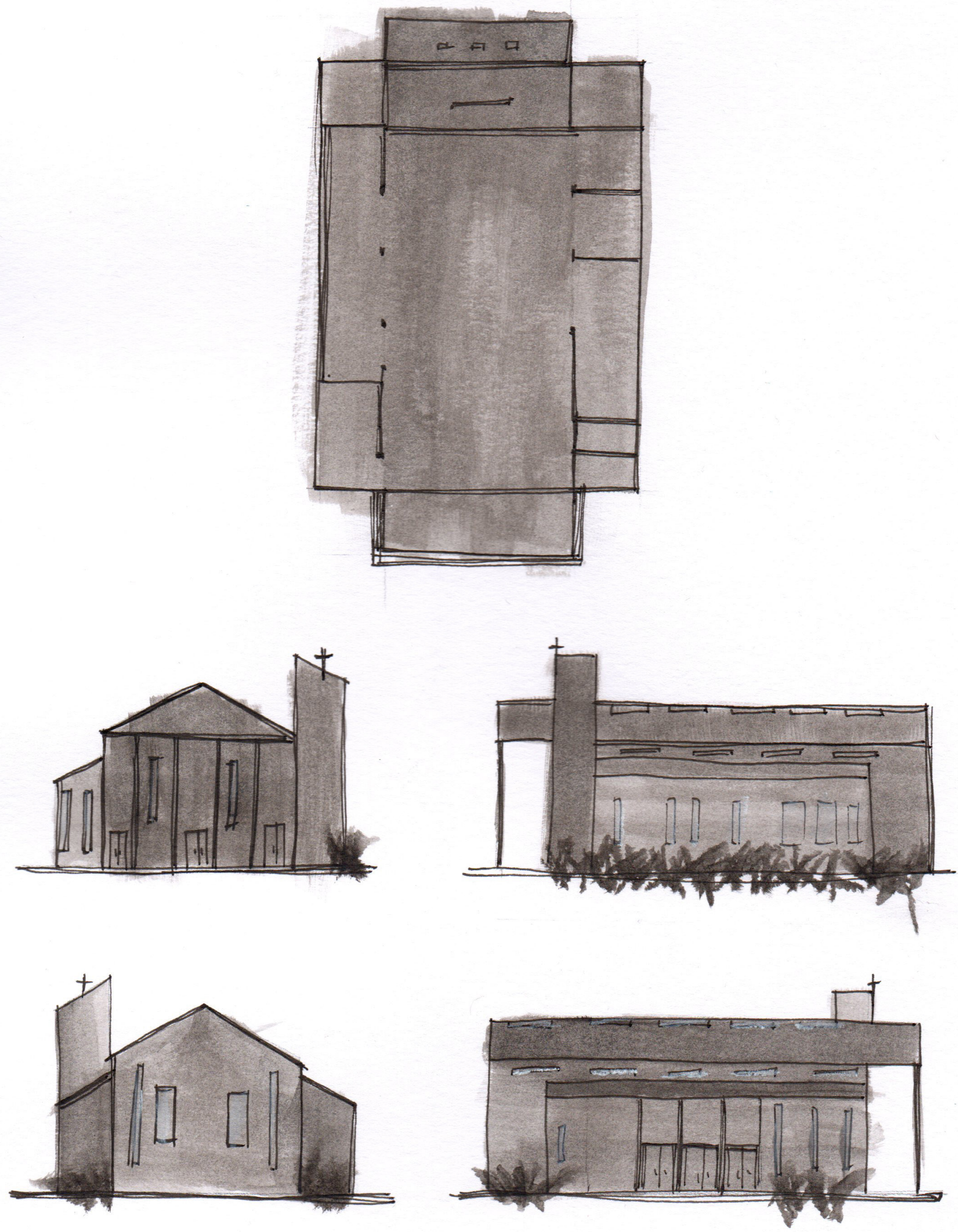
This second concept played around with the idea of height and access in the design. The mono-pitch roof and building form focus on the notion of height and make the sanctuary a focal point in the architecture. The roof slopes down towards it and directs the occupant to close in and focus on the sanctuary. This second concept is inspired by the "intimacy" expressive painting done in the previous section and is a sleek and simple design that provides the architecture with a purpose. The multiple access points and entrances surrounding the building open up the building a lot to anyone and everyone, but it also becomes an intimate experience for the occupant. The architecture starts to close via the roof form, gradually directing the occupant to focus on the sanctuary.

fig8.17 concept 2 sketch 

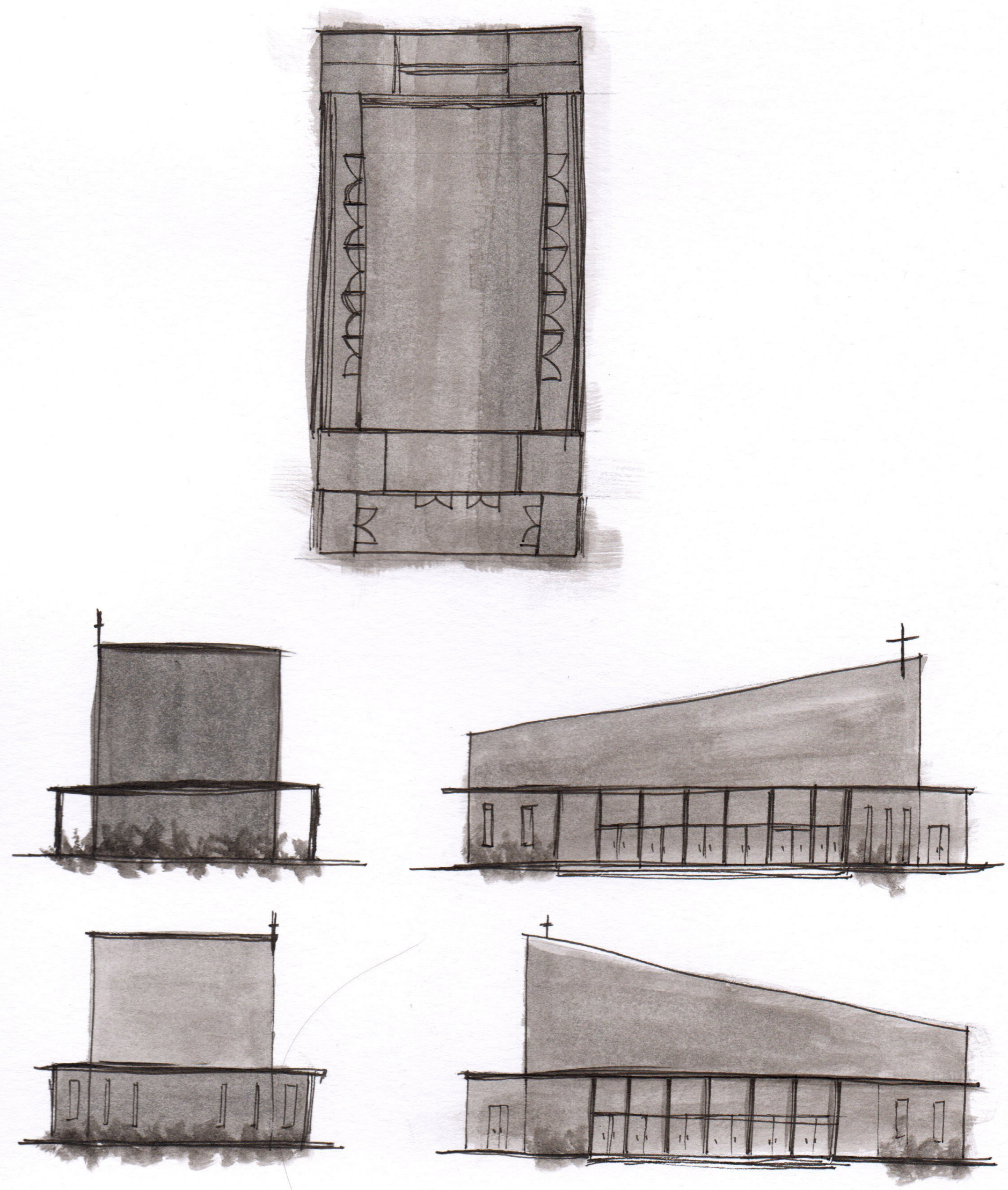
Like the first, thisthird concept also focused on ensuring the design's spaces followed the research and planning previously done. However, unlike the first concept, this drawing started to experiment with angular and rounded forms to direct the occupant to the design's focal point - the large feature cross at the building's front. This architectural feature makes it known to the public that this grand building is a place of worship. This concept strays away from the traditional form by not having its main entrances on the front elevation and instead opts for access from the side. This does not entirely hide the public's main entrance as it is still somewhat visible, but this design choice was made so that the focus could be on the cross and not on the entrance.

fig8.18 concept 3 sketch 

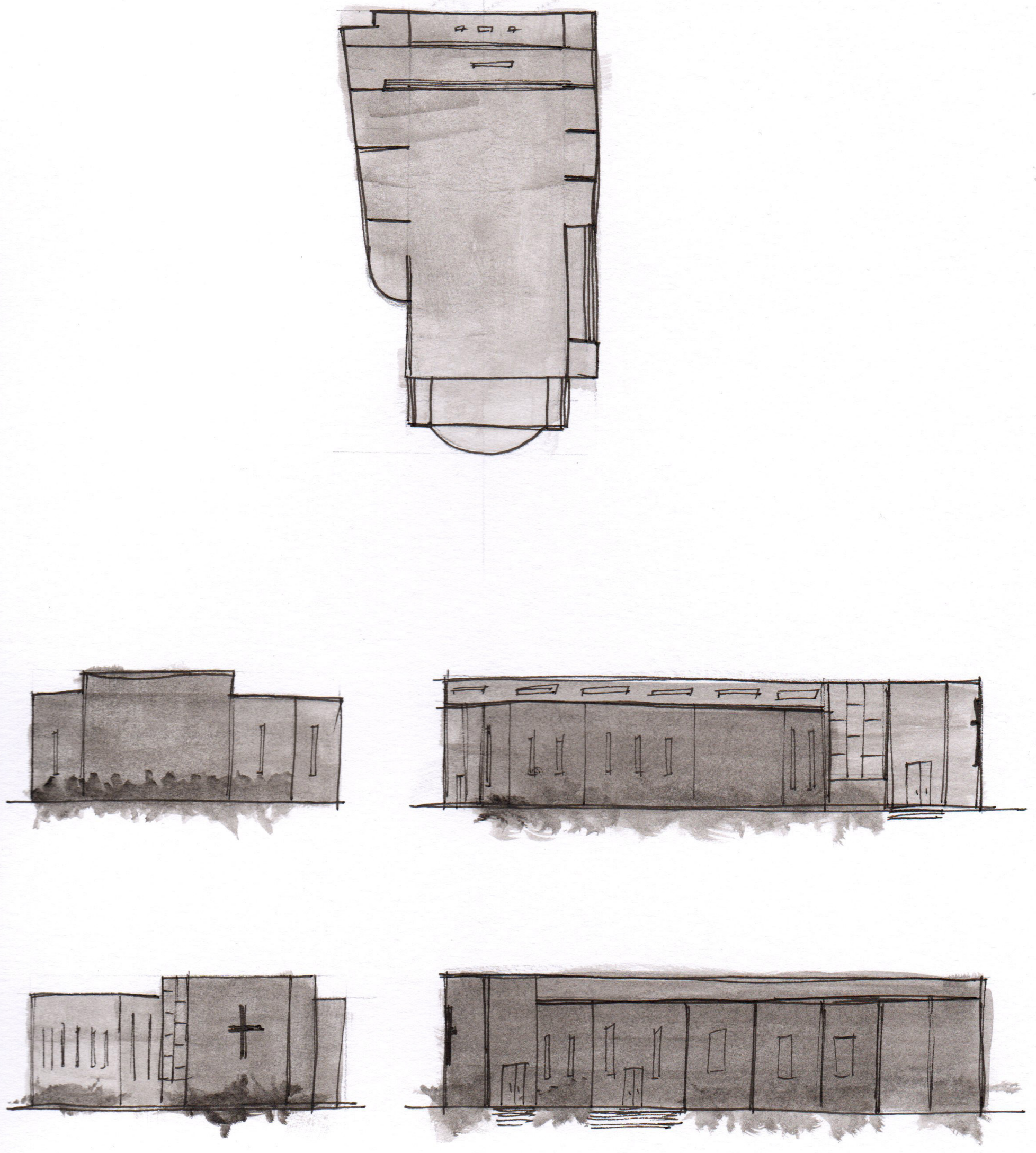
The final concept incorporates a dome for the baptistery, inspired by two sketches previously done that proposed the circular baptistery with a dome idea. This new dome proposed pays homage to the dome in the old Cathedral. This fourth concept idea takes a traditional approach to the layout and look of the building aside from the baptistery. A spire, entrance at the front and sides of the building, and sticking to the conventional floor layout of church architecture show the traditional approach to this design. This concept aims to provide a positive experience in the baptistery as baptism is the welcoming rite into the Church. As discussed before in the previous section, the main idea behind the glass dome and the multitude of windows is to provide as much light as possible to shine down on the person as they are getting baptised to signify that God is present with them.

fig8.19 concept 4 sketch 

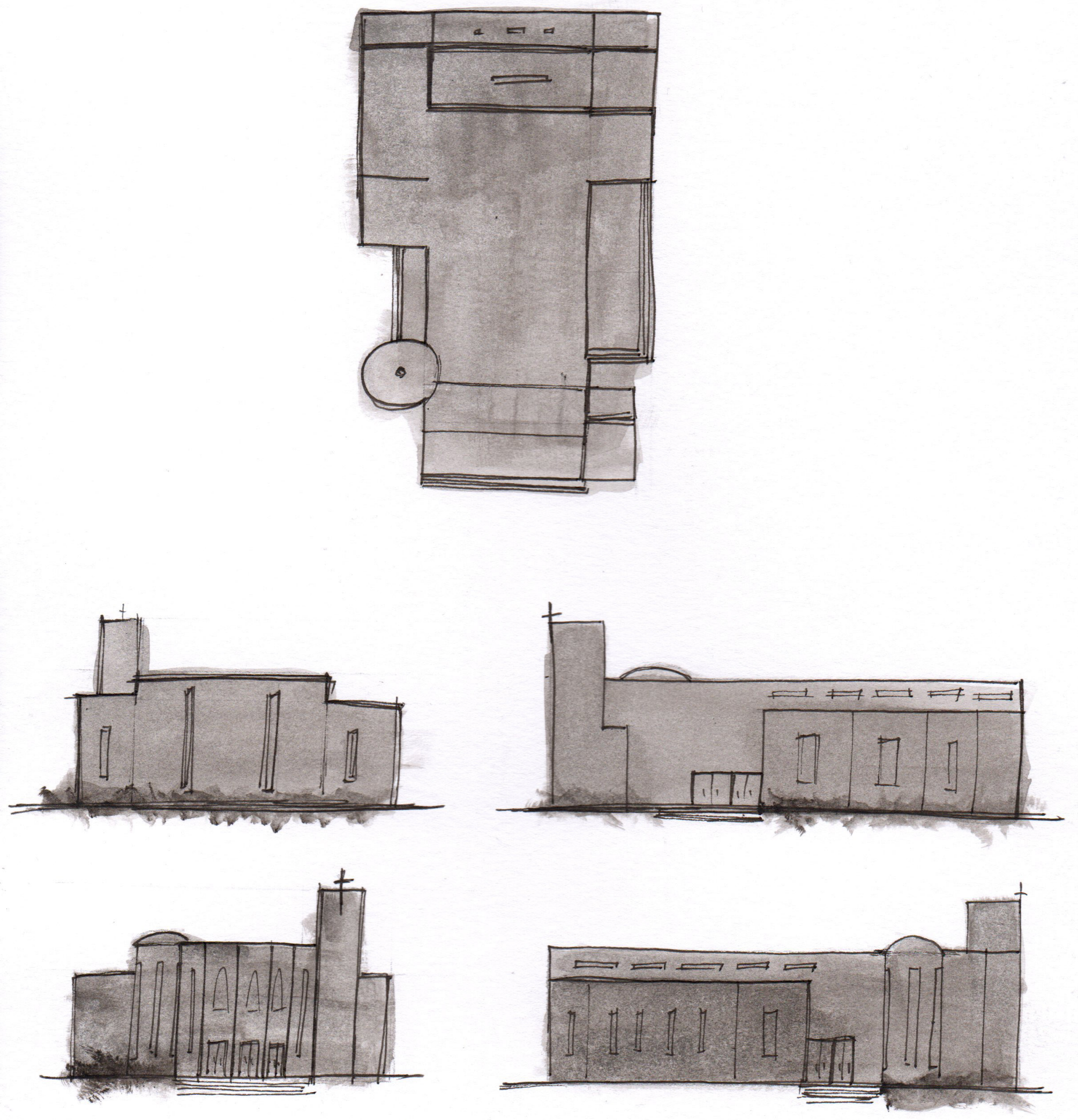


\subsection{CONCEPT CHAPTER SUMMARY}

This chapter showed how the Cathedral concept design started and the process gone through to create four different concepts to be further developed. Research on how churches operate kickstarted the design stage as this was followed by producing expressive sketches and paintings to help visualise findings in the research. Different diagrams were also used to analyse the spaces needed in the Cathedral, which helped visualise how the relationship of spaces would operate and benefit the occupant. The four concepts produced in this chapter have somewhat a modernist approach to the formation of the design, where the function of the rooms and how they relate to each other has dictated the layout and building form. 


\section{CHAPTER 9}

PRELIMINARY
DESIGN 
Further research is done in the development stage to understand ecclesiasticalarchitectureona deeper level. The changes brought on by Vatical II was empirical as it addressed the relationship between the Catholic Church and the modern world. As the world is confronted and challenged by Vatican II with the gospel's demands, the architecture must follow and support the vision brought forward (Schloeder, 1998, p. 34). While also speaking to contemporary society and modern humanity of the source of faith, vibrant and robust architecture that is deeply rooted in the Church's traditional and enduring forms must be made (Schloeder, 1998, p. 34).

Architecture in the church is not limited by style, theory, or expression as there is no "religious technique" to art, and there is no single style to churches (Schloeder, 1998, p. 42). Within Church architecture, many styles throughout the ages have been developed and accepted. Vatican II emphasizes that the Church is open to any style as it does not claim any particular style exclusively (Schloeder, 1998, p. 42). The Church only requests that no matter the style, it "bring to the task the reverence and honour due to the sacred building" (Schloeder, 1998, p. 42).
From the previous conceptual drawings produced in the section before, each concept had the potential to be further developed, and each produced different design aspects that were individually successful. Based on findings from further research done and from the different design aspects each concept brought, the conceptual designs produced earlier were refined in the hopes of advancing toward a developed design by merging the different aspects and ideas.

In this design stage, the design produced was formed by combining different ideas from the earlier conceptual drawings. The first stage of preliminary design was focused on bringing the ideas of the cross being an architectural feature and the circular baptistery and dome together. When designing a Church and planning the spatial configurations, it is vital to note how each space within the building will be used and what emotions or feelings will be evoked. Only three sacraments demand major specific architectural consideration when designing - the Eucharist, baptism, and reconciliation (Schloeder, 1998, p. 111). The other four sacraments and planning for a funeral mass only require sufficient space at the top of the nave just outside of the sanctuary and main aisles that can be widened (Schloeder, 1998, p. 111). It is essential to include the considerations in the design process, no matter how big or small, to help create a Church accessible to everyone and where all sacraments can be administered appropriately (Schloeder, 1998, p. 111). The floor plan of the third concept was altered to make some adjustments to develop the design and adhere to the Church's spatial guidelines. 

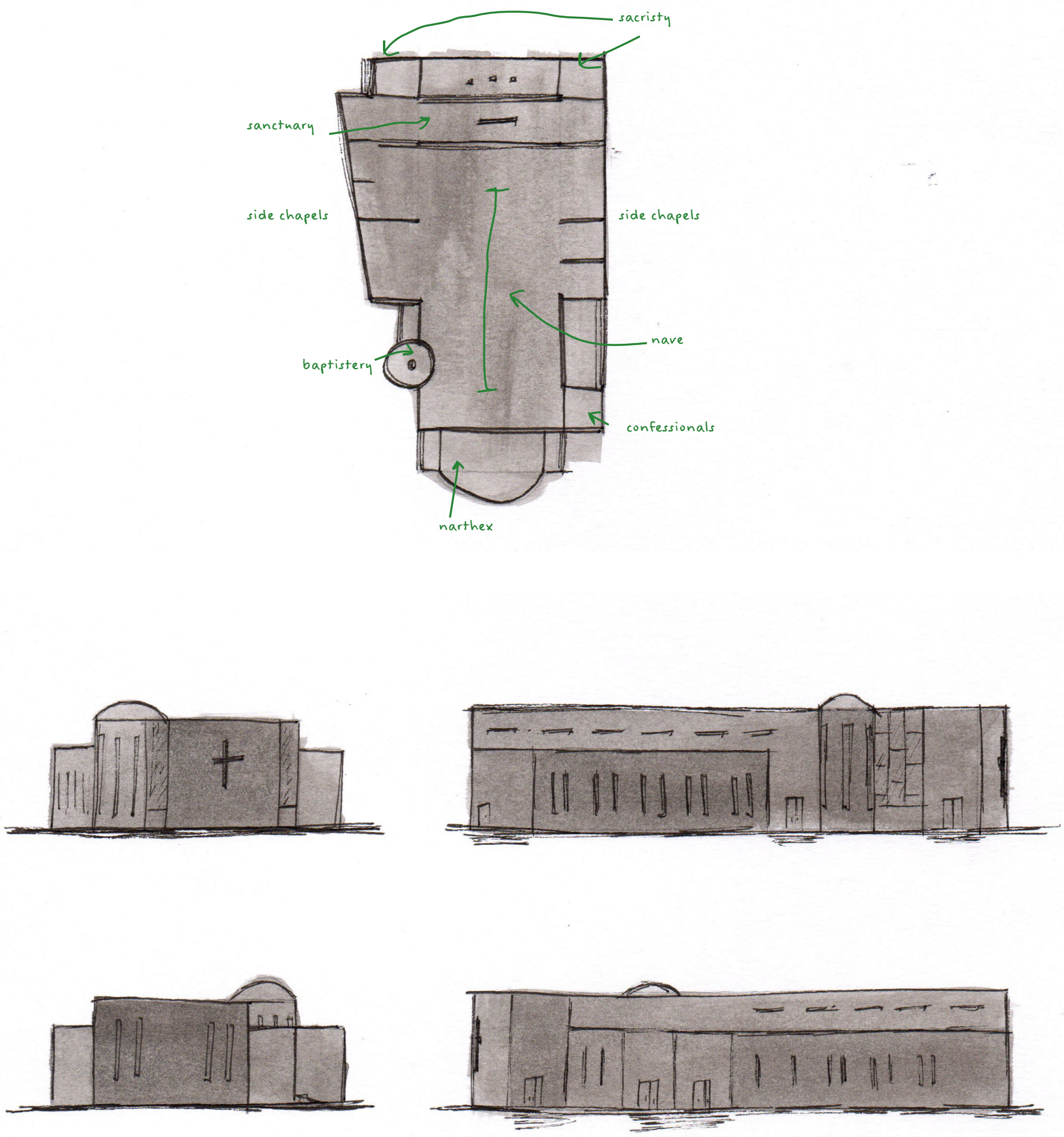

fig9.01 first stage of preliminary design 
To further develop the building form, various walls inside the building are shifted to create a floor plan that is more open and organized. The mono-pitch roof in the nave from the second concept was also adopted as an idea. It provided the design with height and the feeling of being in the presence of a towering grand building from the front elevation and responds to the multistorey hotel's towering opposite the site. As discussed before, this mono-pitch roof also addresses the idea of intimacy in an open space as this roof directs the occupant's view to the sanctuary and allows the occupant to have an intimate experience with the altar and the crucifix.

fig9.02 second stage of preliminary design
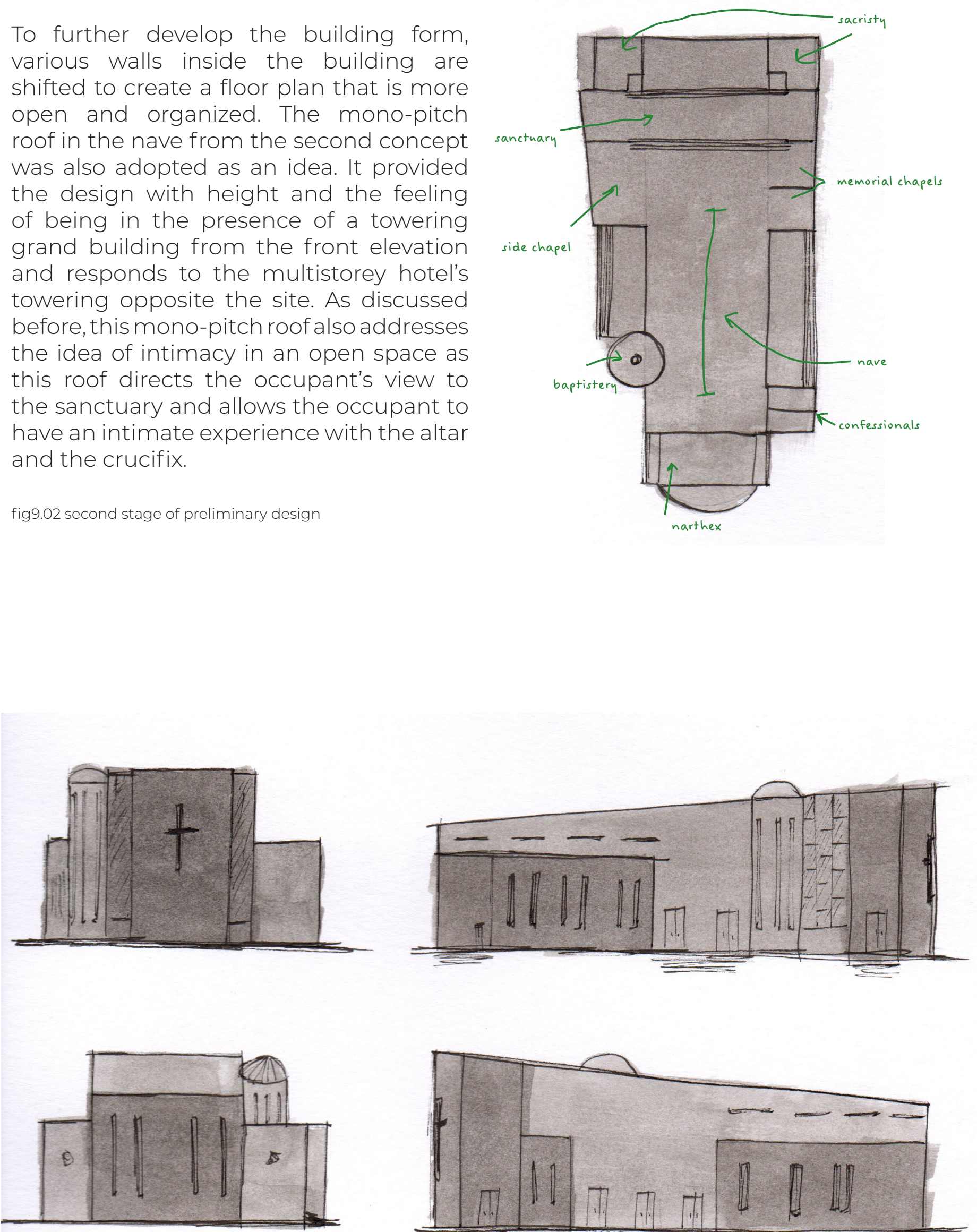

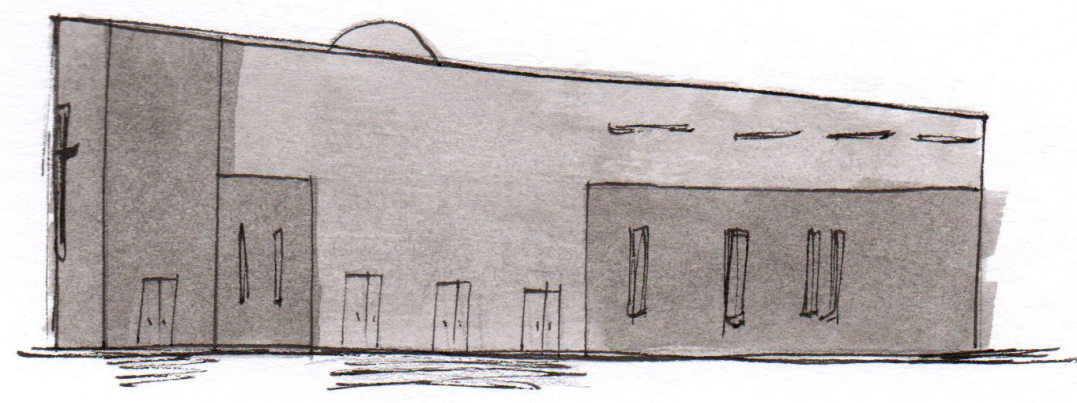


This stage only provided minor changes to the design, particularly in the elevation concerning the side roofs of the Cathedral. These changes were focused on providing cover for the side entrances so that people would be sheltered while entering and exiting the building. It also gives these roofs a downward slope in the opposite direction of the nave roof to give the building more dimension and accentuate the building's sheer height and make it feel grander. It was important to refine the exterior of the Cathedral as it represents what is happening inside and is also important for the building to respond to the surroundings and have a relationship with the other buildings around as the a building type, the Church has a unique relationship to the other building types in the urban fabric (Schloeder, 1998, p. 225). As the Church is "a sign and symbol of heavenly things", its representation of the sacred creates a break in the urban fabric of profane and non-religious life (Schloeder, 1998, p. 225). church has an iconic function, wherein as

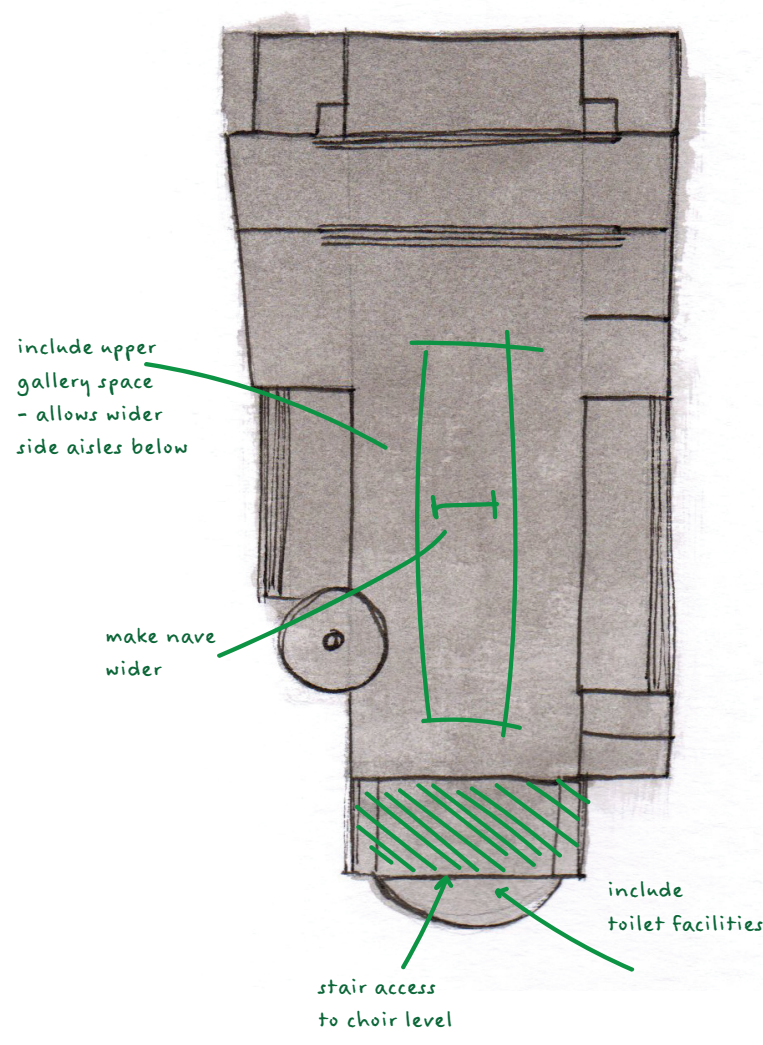

fig9.03 small changes made to develop the preliminary design
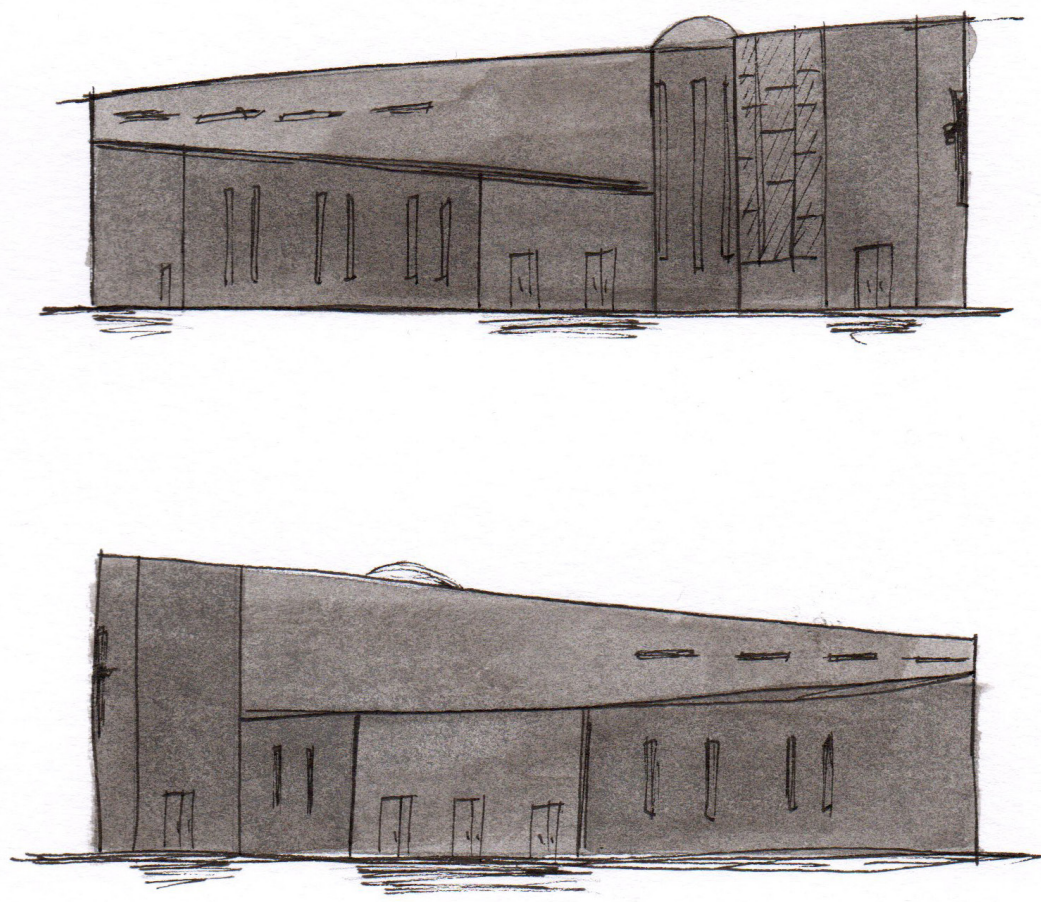


\subsection{MATERIAL USES}

While much of the design done so far has been on the building form and layout, it is essential in the design process to start considering the other materials that need to be reused from the old Cathedral. In the design, every aspect of the church building must be of the highest quality available. Every single last detail in the design needs to be clean, simple, and of high quality, befitting a building dedicated to God (Schloeder, 1998, p. 42). The nature of the liturgy and its dynamics, historical forms and precedents, the tradition of architectural meaning and iconic symbolism, and liturgical laws need to be

\subsubsection{CONFESSIONAL DIVIDER}

The sacrament of reconciliation has had an architectural setting only since the 16th century when Saint Charles Borromeo at the Council of Men ordered a partition between the penitentand priest topreserve the dignity of the sacrament (Schloeder, 1998, p. 124). Before the partition, the penitent would usually confess their sins while kneeling in the nave or the Church's narthex, with the priest sitting beside them (Schloeder, 1998, p. 125). Although daunting having to confess one's sins to a stranger, the partition provides privacy to the penitent. When designed correctly, the architectural setting for the sacrament of reconciliation should be "seen as inviting and a reminder of the Church's healing ministry" (Schloeder, 1998, p. 125). When designing the confessional, it is essential for the penitent not to be instantly confronted by the priest but to have the option to adopt a kneeling position behind carefully understood as they influence the design (Schloeder, 1998, p. 42). Every aspect of the Church design needs to refer back to the liturgy. Nothing in the design can be unnecessary or carelessly considered as it would have nothing to offer or teach that would bring the occupant closer to God (Schloeder, 1998, p. 42). As mentioned before in the previous section regarding material opportunities for the various materials in the Cathedral that could be reused, this section will start to explore further on those materials and how they could be used to create different meaningful architectural features in the design.

a screen/partition or to kneel or sit within sight of the priest (Schloeder, 1998, p. 125). The confessional room should be light, airy, comfortable, and simple and should also be well lit and ventilated and indicate occupancy via an obscure glass door or a signal light (Schloeder, 1998, p. 125). The only furnishings needed in the confessional, apart from the kneeler and screen, are chairs for the priest and penitent, a small table for the Bible and priest's stole, and finally a crucifix or other appropriate images on the wall (Schloeder, 1998, p. 126).

As the partition in the confessionals hold such a significant role in the Church, designing a privacy divider and screen in the confessionals made from the kauri wood used for the old Cathedral's roof framing would enhance the space. The confessional partition made from old materials is representative of the idea of rebirth - new beginnings for old materials and new beginnings after confession-it brings a deeper meaning to the sacrament and to the space. 
intent was to create a shelter of

some sort but has ended up be-

ing too closed in, un

feeling trapped

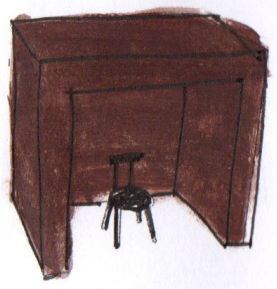

too solid and block

off communication

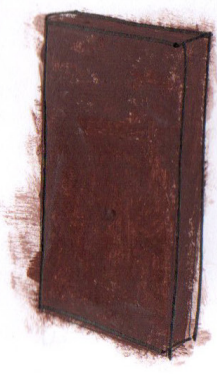

too open and gets rid of

the sense of privacy needed

in the sacrament

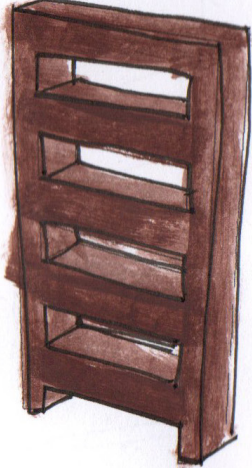

smaller gaps allows the much needed privacy while not feeling disconnected to the person on

the other side of the divider
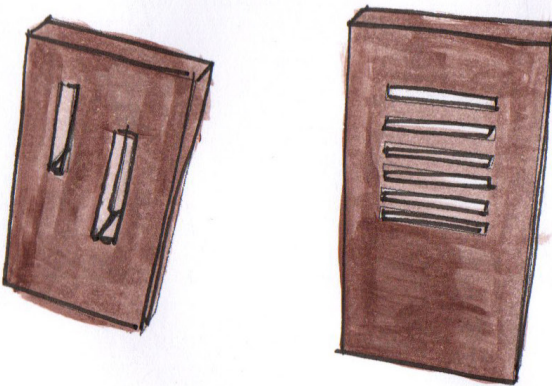

fig9.04 sketches of different ideas for confessional divider reusing the kauri wood roof framing

fig9.05 perspective drawing of confessional divider providing privacy

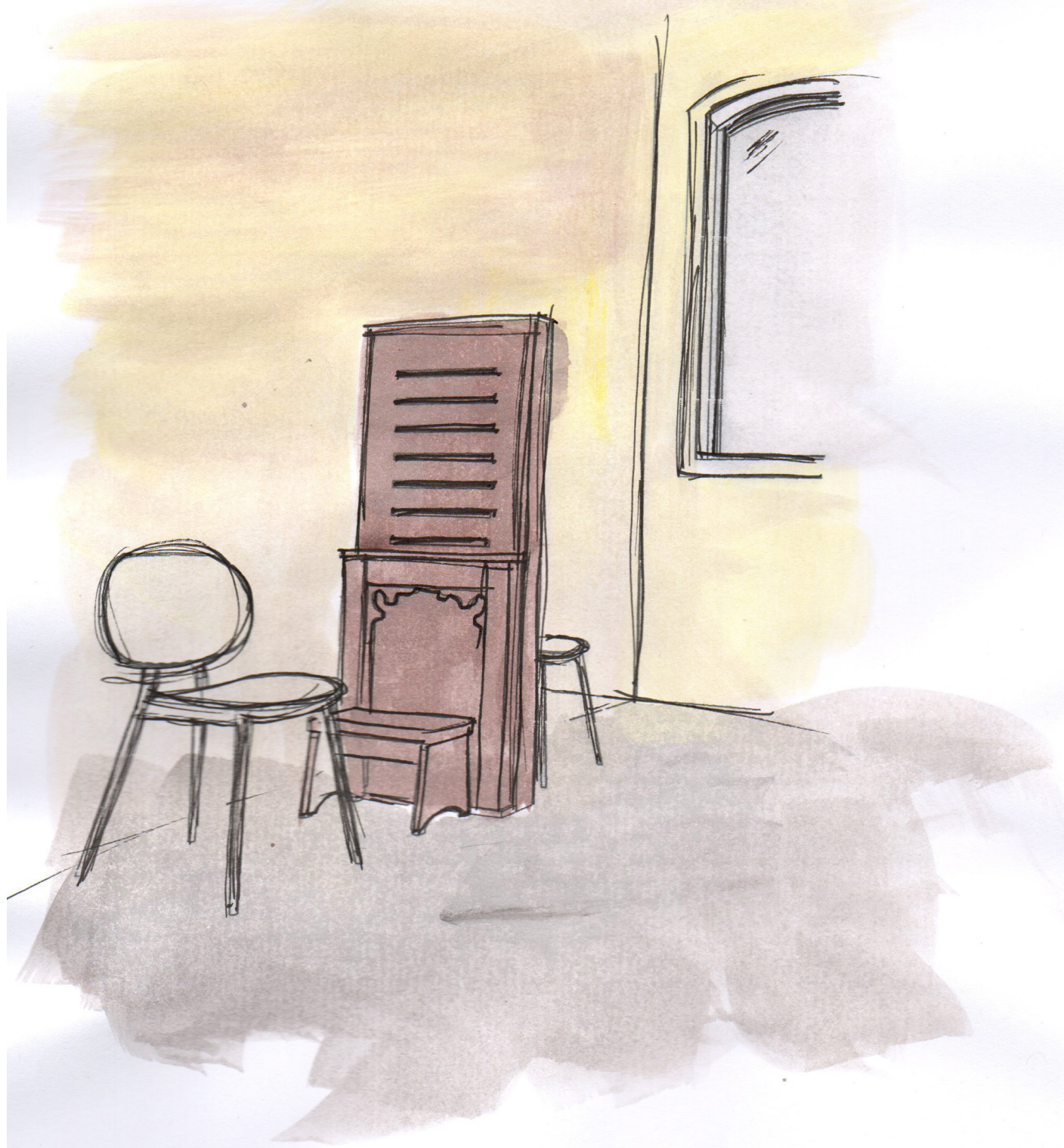




\subsubsection{SANCTUARY CRUCIFIX}

As the focal point in the design, it was essential to make the sanctuary crucifix a significant design feature. Made from the kauri wood roof framing of the old Cathedral, it was explored how this crucifix could be made into a unique and memorable design for the new Cathedral. By layering the wood framing, a distinctive design that holds so much history and value for the new Cathedral has been created. As the theme for this thesis and design is "rejuvenation," it is exceptional to see how the new life could be brought to the old materials in different ways and how they could help share the history it comes with.

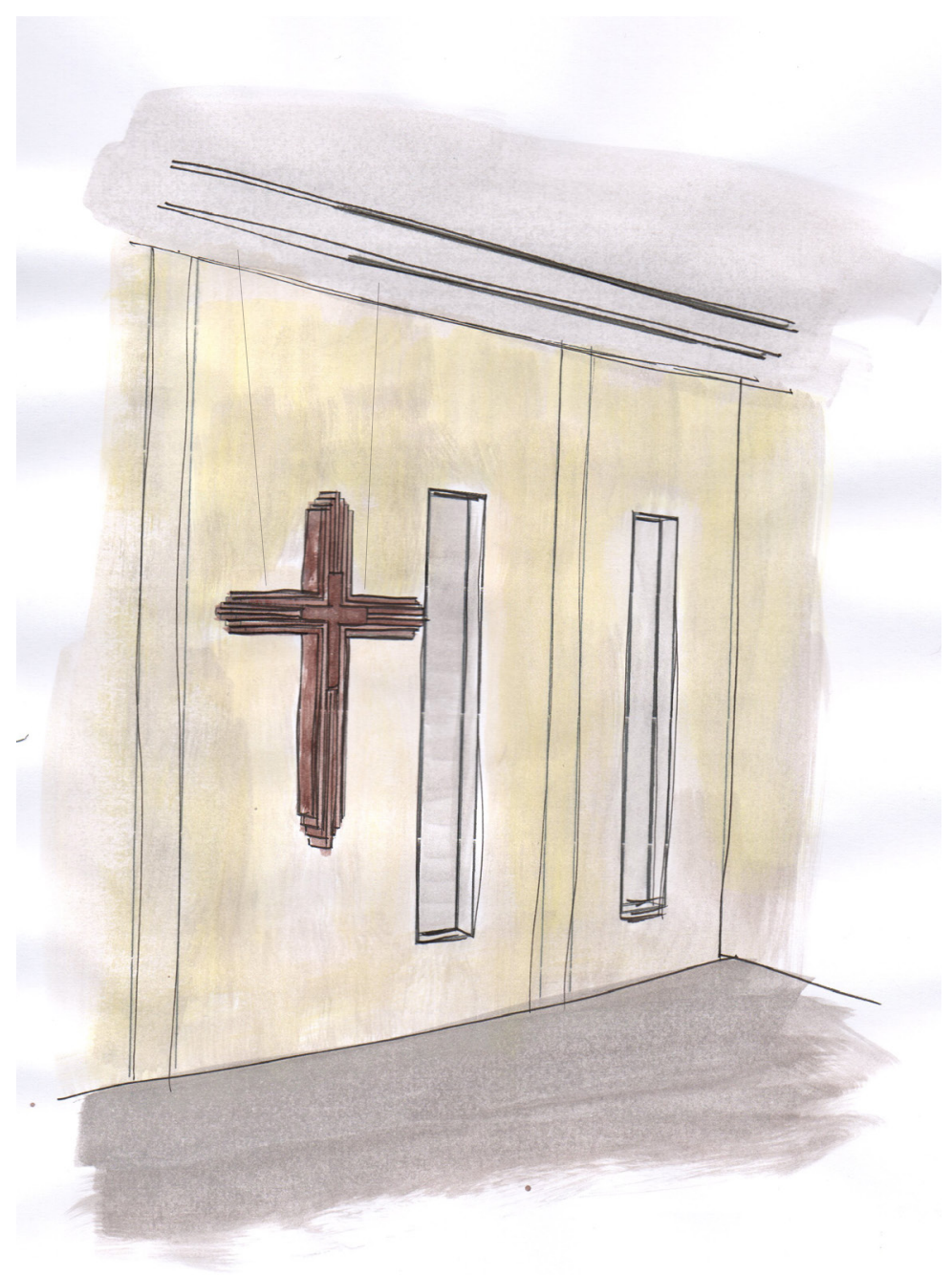

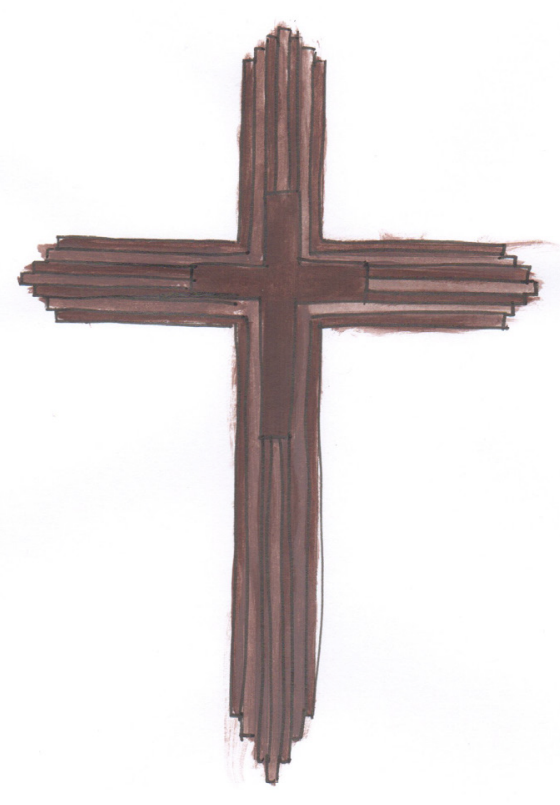

fig9.06 design for the sanctuary crucifix, stacking different planks of wood from old roof framing to create a crucifix that is unique and holds history

fig9.07 perspective drawing of crucifix hanging from ceiling in sanctuary 


\subsubsection{ENTRANCE/NARTHEX CEILING}

When one enters through the main entrance doors to the narthex, the kauri wood used for roof framing is now reused as timber slats that line the ceiling. This provides the space with a welcoming feel and provides the space with more colour and texture than just the limestone cladding used on the walls. The timber slats with strip lighting in between also provide the space with a modern aesthetic.

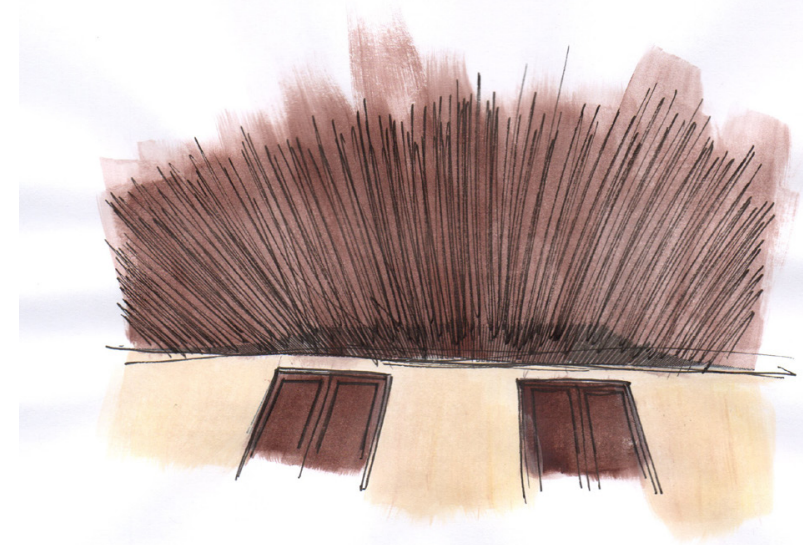

fig9.08-9.09 perspective drawings of narthex with timber slats on the ceiling as an architectural feature to make the space feel inviting

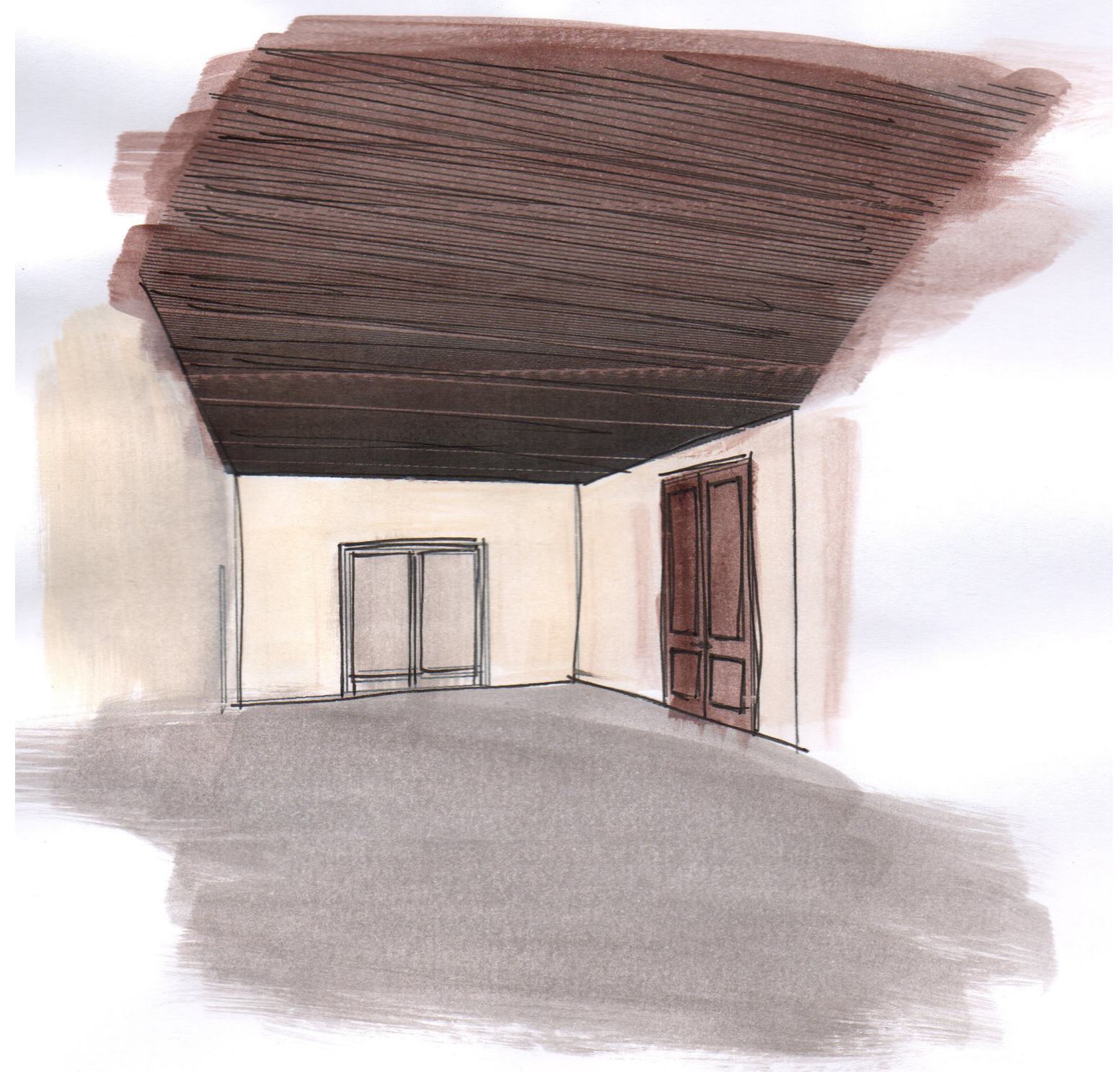




\subsubsection{COPPER FEATURE WALLS}

In the memorial chapels where the previous bishops that wished to be buried in the Cathedral will be buried, the old dome's green copper roof will be reused as panels to create feature walls in the design. These walls will highlight the memorials for the bishops. As the bishops initially requested to be buried in the old Cathedral, it was essential to bring a piece of the Cathedral that they served into their chapels to pay tribute.

fig9.10 copper feature wall in the memorial chapel

fig9.11 copper feature wall in the side chapel providing a nice backdrop to the small altar

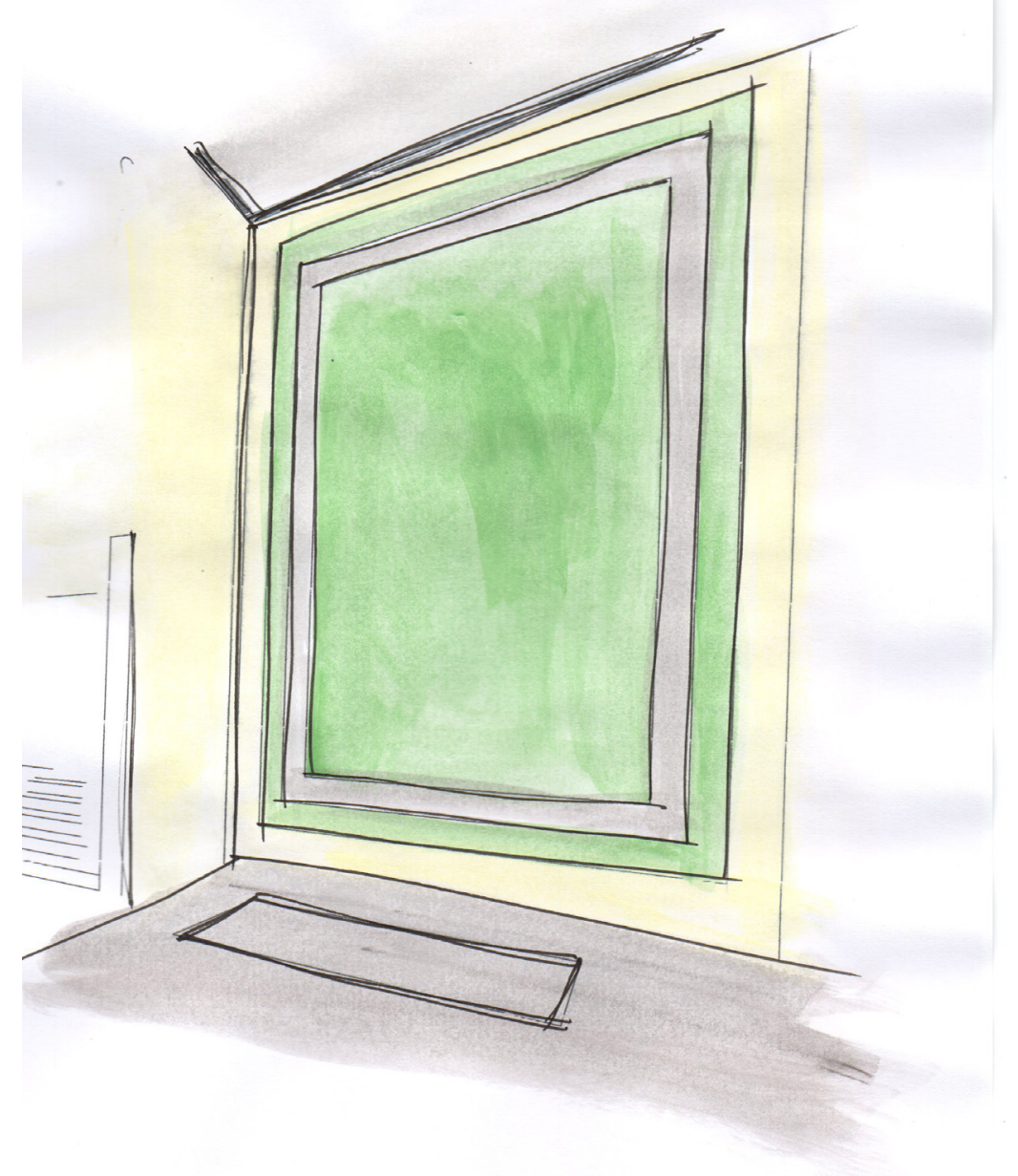




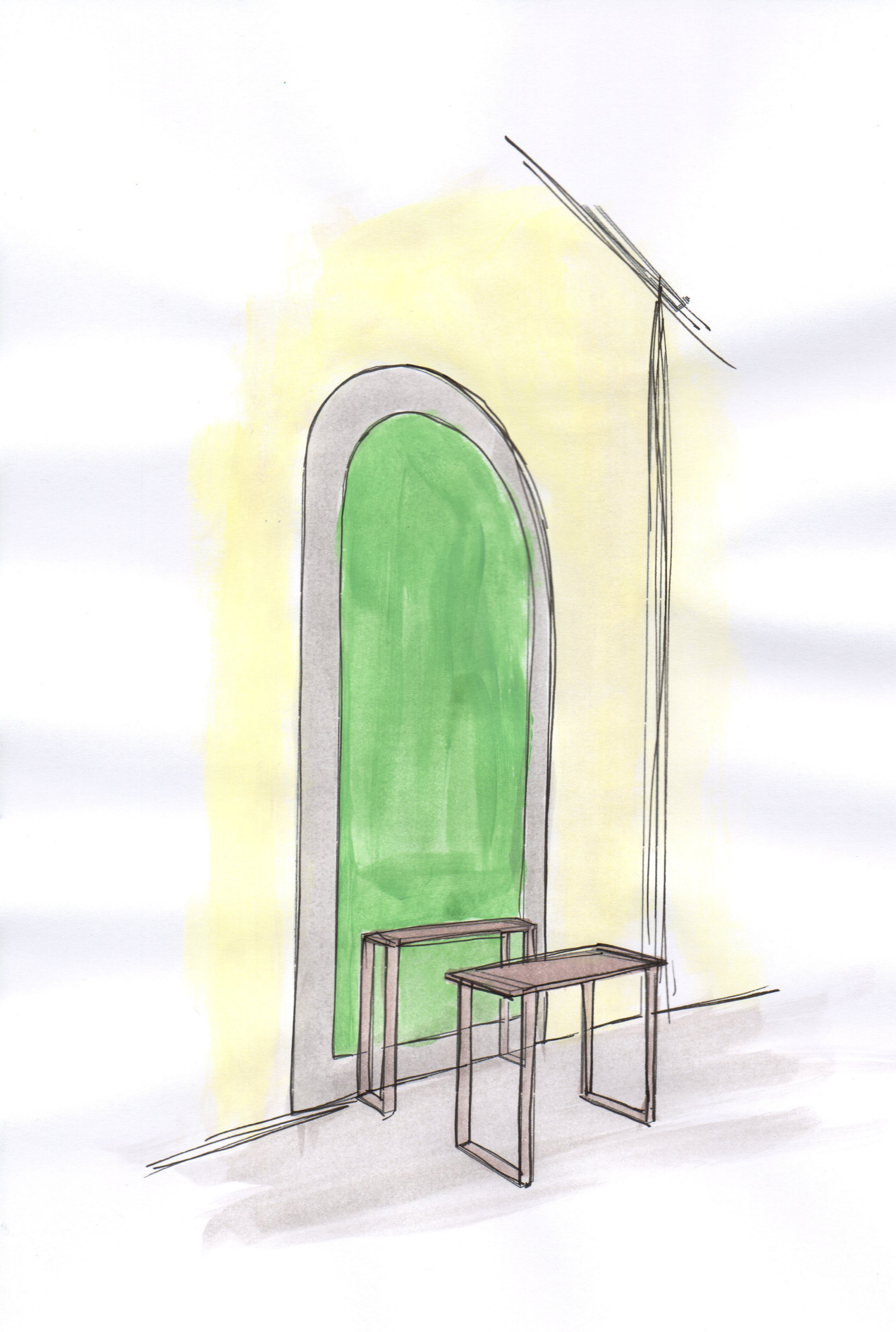




\subsubsection{STATIONS OF THE CROSS GARDEN}

The ionic columns from the old Cathedral are another material that will be reused on the new site. These columns will be used in the stations of the cross garden proposed for this design. It was explored how the 14 columns marking the stations of the cross could be laid out in the back garden. It was essential to create a design that allowed the story in the stations of the cross to be clearly followed and accessible to everyone. It was also essential to design a garden full of life and colour that leaves people with a positive experience when in the garden. fig9.12 sketches of different ideas for layout of stations of the cross garden

fig9.13 perspective sketch of stations of the cross garden
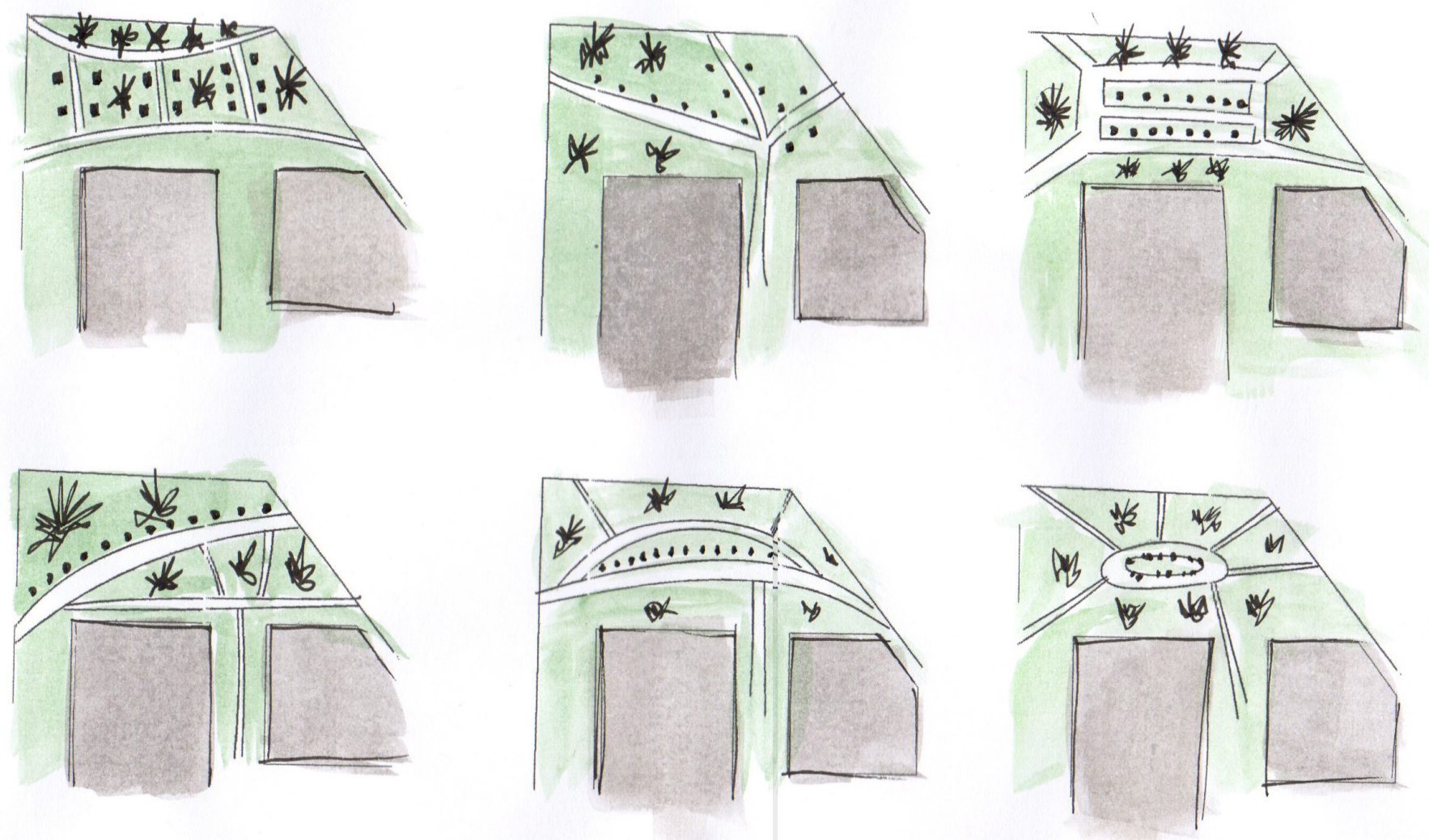


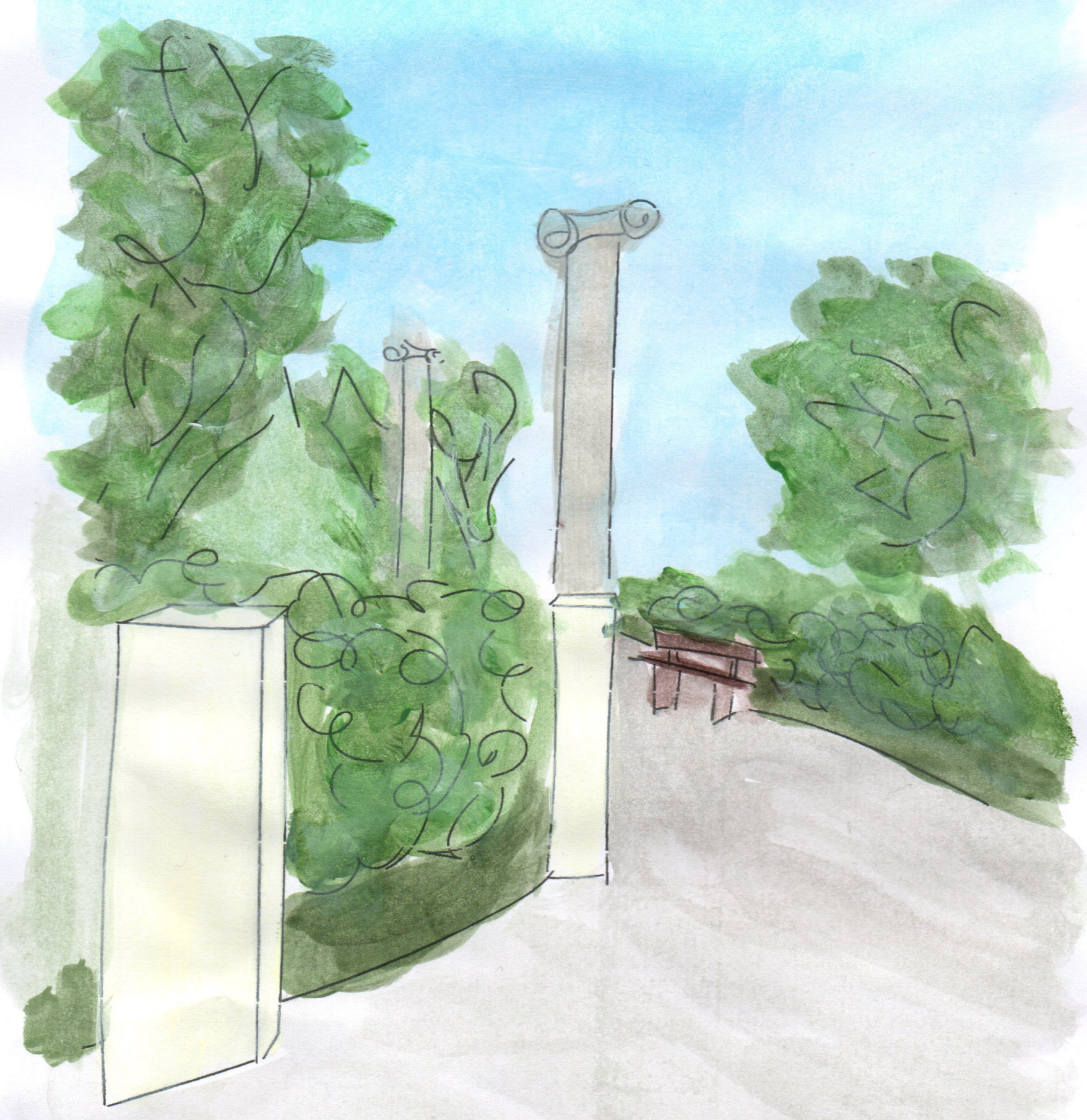




\subsection{PRELIMINARY DESIGN CHAPTER SUMMARY}

For contemporary churches to take their rightful place in the architectural dialogue, the Church needs to be both modern and traditional (Schloeder, 1998, p. 225). While there is no set Catholic form or style, like all other parts of the Church, the buildings' architecture must be rooted in the common language of the Church (Schloeder, 1998, p. 226). In the case of buildings, the language of historical precedent must be considered in the design. However, this should not limit the building form to a traditional style and should instead also adapt the form to be relevant to the present time and conditions (Schloeder, 1998, p. 226).
In the preliminary stage of the design, the focus was on working towards having a concrete and set design that was able to be further developed and finalised in the next section. More research was brought into this stage to help develop the architectural narrative and meaning within the building's function and concept. As this design aims to reuse old materials to hold the old Cathedral's history in the new design, this stage focused on how the different materials were going to considered in the architecture and it was important to research how the materials could play a role in storytelling. 


\title{
CHAPTER 10
}

\author{
DEVELOPED \\ DESIGN
}




\subsection{DEVELOPED DESIGN INTENT}

The developed design for a new Christchurch Catholic Cathedral has been visualized by exploring the idea of preserving heritage value by using the demolished building materials of the old Cathedral while following Church architecture principles. The aim was to create an architecture that respected the past while creating something new, functional, and appropriate to its setting. Situated on the corner of Colombo and Armagh St, the developed design adopts a simplistic form that does not stand out too much in a city where architecture is still transitioning between traditional and unconventional/experimental while rebuilding after all the destruction left in the city. The design has been carefully researched and planned, following the Church's guidelines to achieve a design that refers back to the celebration of the liturgy and the participation of its people. The developed design focuses on creating a graceful and simple form to achieve a feeling of simplicity, elegance, and transcendence that does not distract the viewer/occupant.

This thesis has produced a design for the new Christchurch Catholic Cathedral through research and design experimentation that aims to fulfil four key considerations: history, liturgical function, urban integration, and architectural significance.

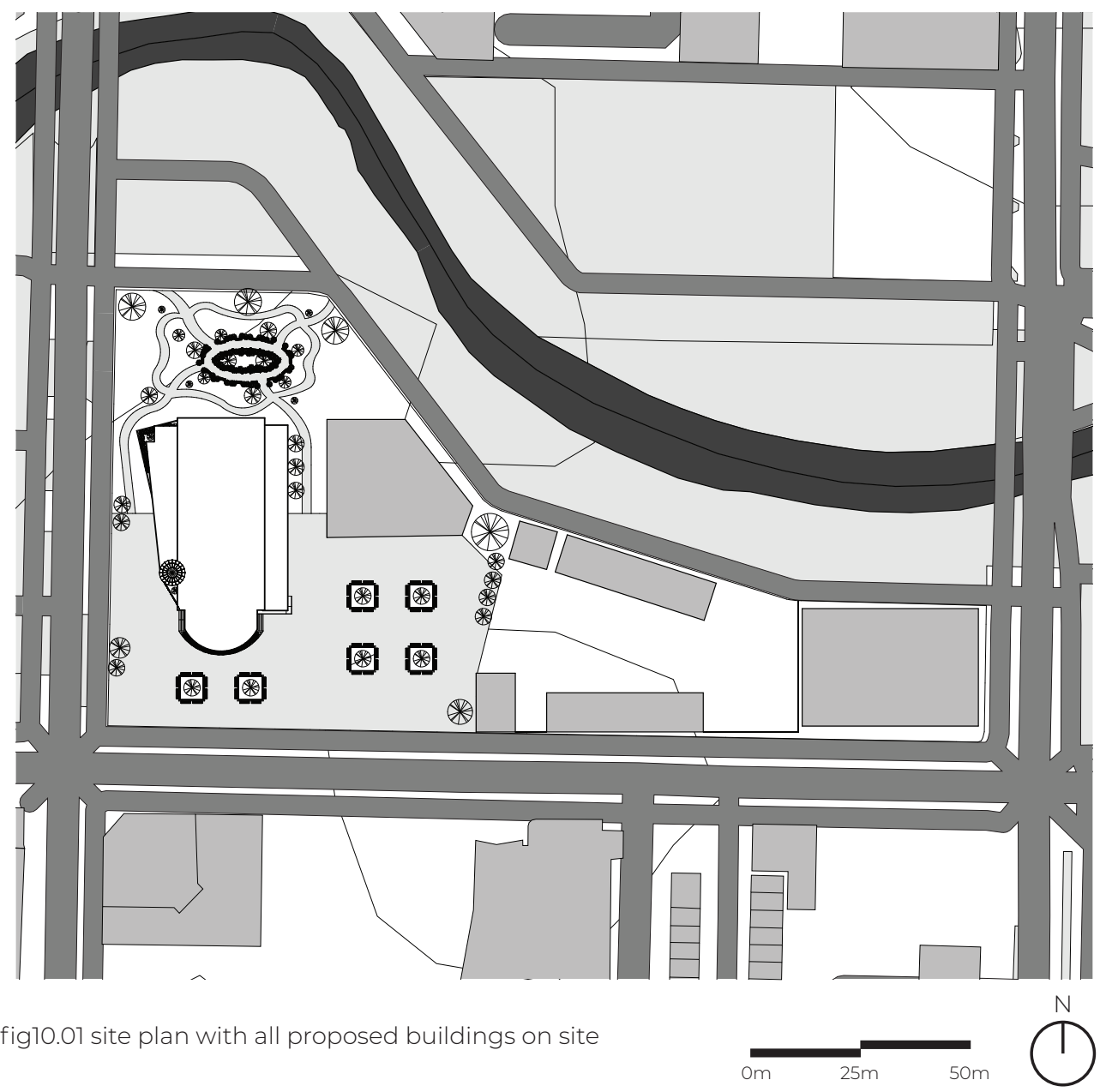




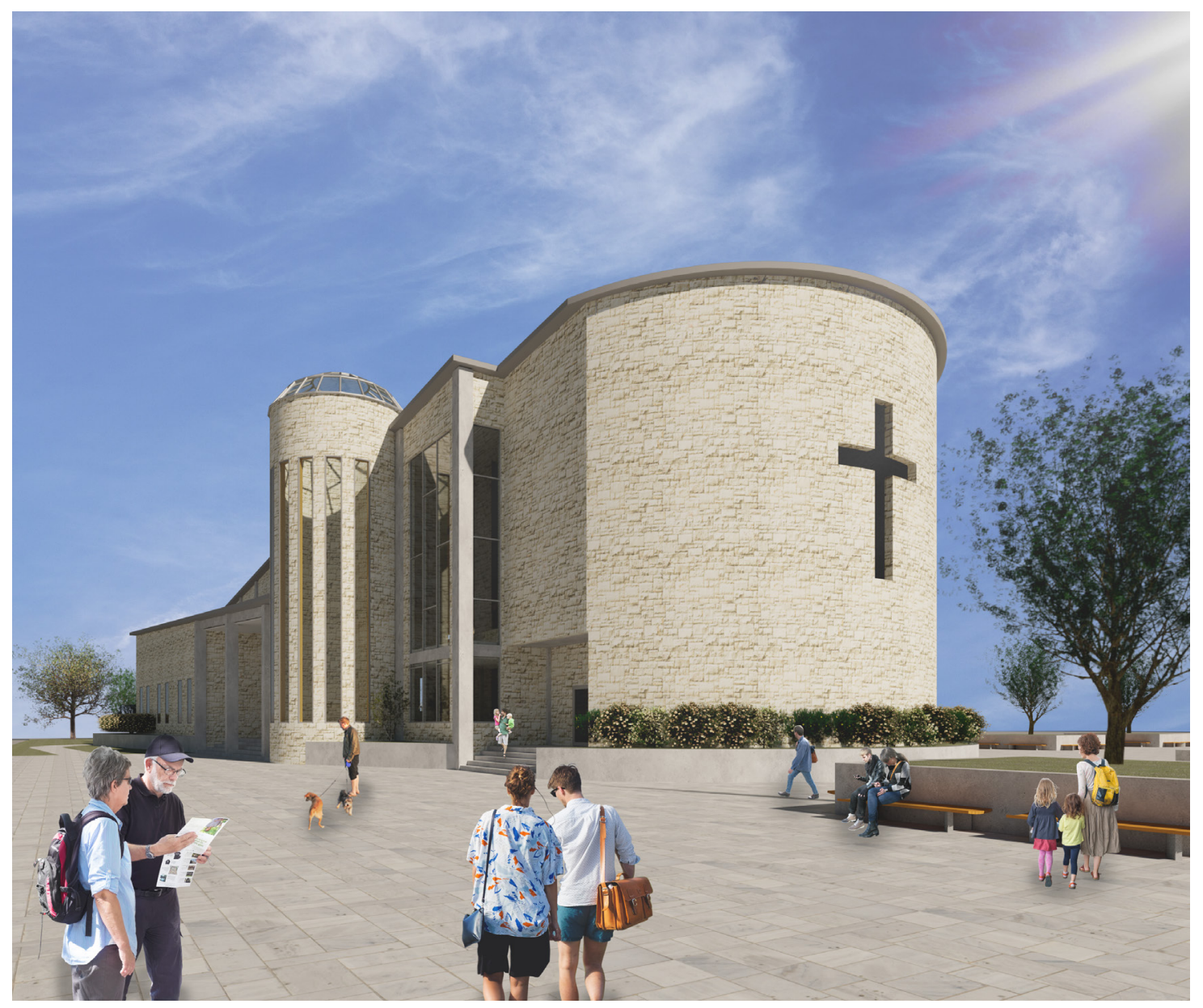

fig10.02 exterior view of the cathedral, offering a preview of its architectural form and heavy focus on the reuse of materials while people interact outside with the site

fig10.03 cathedral site plan showing the cathedral itself as well as the stations of the cross garden at the back and a small plaza at the front, aiming to bring people onto the site and interacting with these public spaces

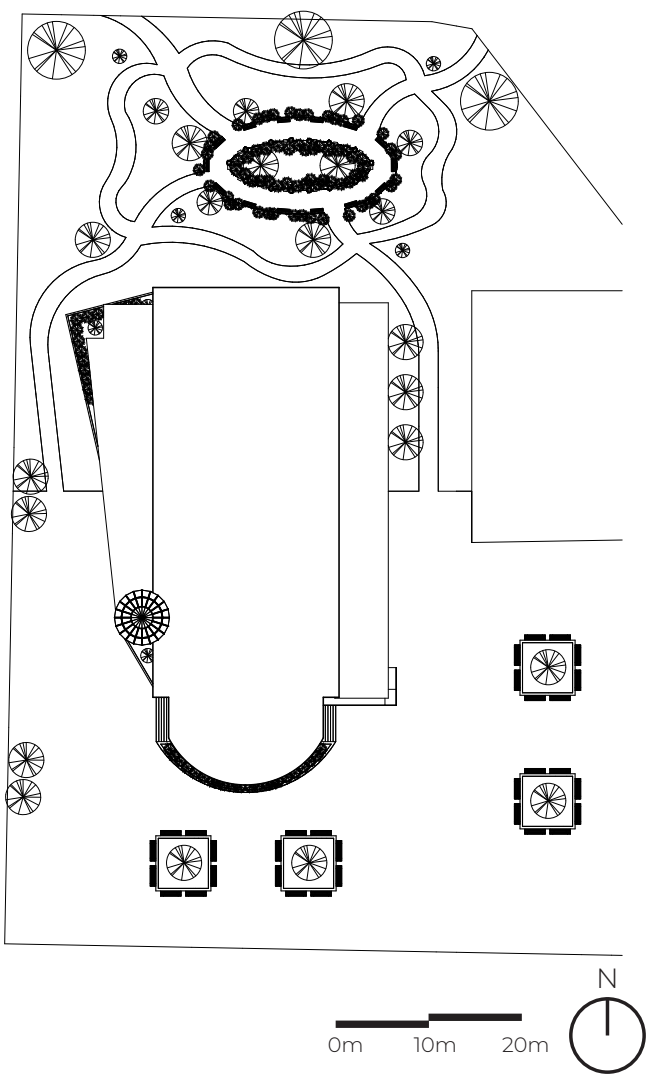




\subsubsection{SPATIAL ORGANISATION}

The spatial organisation of the different spaces required in the Cathedral was thoroughly researched and planned. Research and analysis on how the spaces successfully function and relate to each other, the symbolism and significance of these spaces, and experimenting with different layout configurations have helped provide the design with a layout that is easy to understand and navigate. While mostly following the traditional layout of the Cathedral, the analysis and trialling of different spatial configurations has led to a developed design that has somewhat of a modernist approach to it, where the function of the Cathedral ultimately dictated the building form of the architecture.

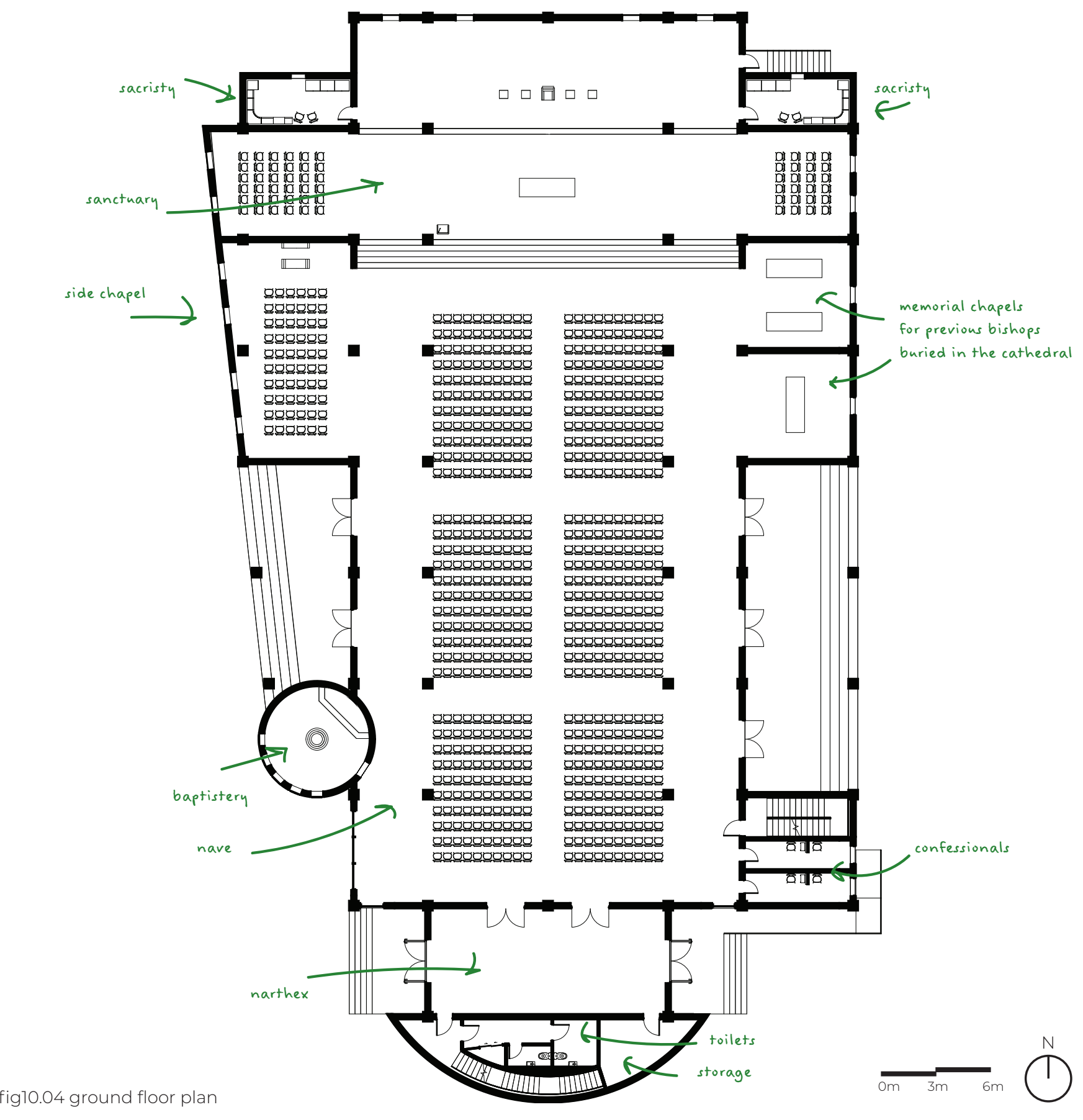


Many of the spaces in the Cathedral have different functions and different relationships with each other. The design's architectural language and how the spaces are laid out is a language that does not stray away from the traditional layout.
The new Cathedral design needs to be rooted in historic precedent for the architecture not to get lost and be misunderstood by its users. The developed design has aimed to create a traditional and modern building simultaneously, just as how the Church suggests when designing new sacred buildings.

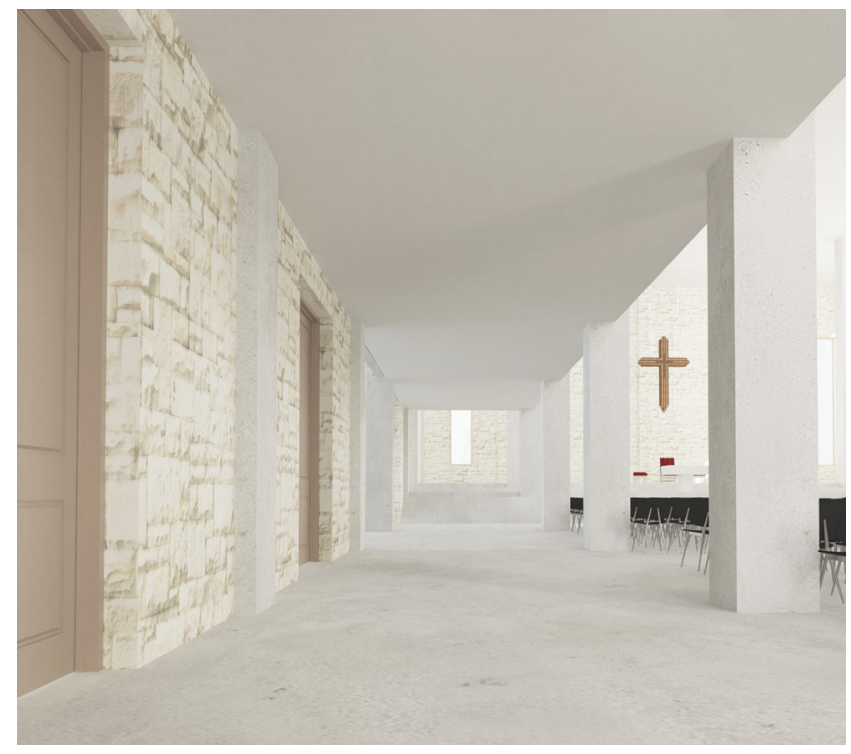

fig10.06 view from the west side aisle under the upper gallery

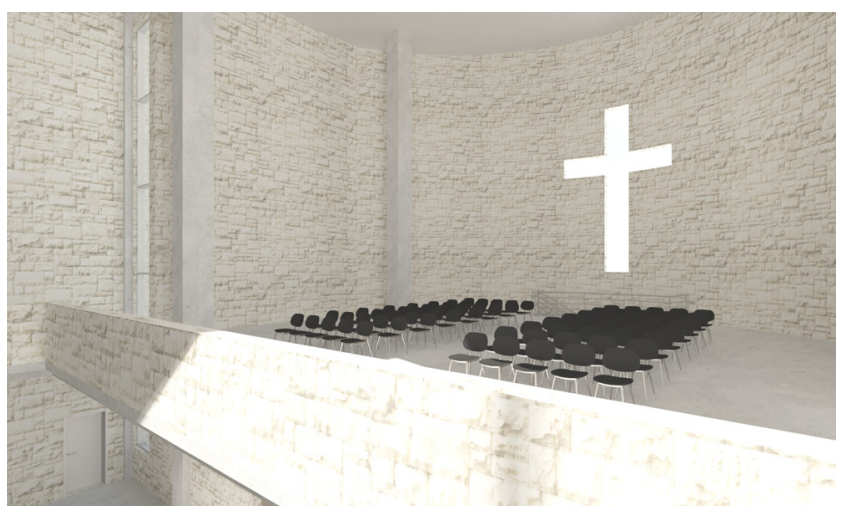

fig10.05 choir level floor plan

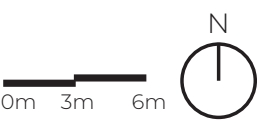

fig10.07 choir area overlooking the nave with the large cross opening providing a background and bringing light into the space 


\section{CONFESSIONAL}

While the whole building is seen as important and significant, a few spaces in the Cathedral hold more importance and meaning than others. There has been a focus in this thesis on the design of the confessionals, baptistery, sanctuary, and nave due to their significance and role in the liturgy and the meaning some of them hold in their space.

fig10.08 confessional room. reused kauri wood has been used to create confessional divider between priest and penitent
The confessional in the design of the Cathedral is a dedicated space for the sacrament of reconciliation. It adopts a straightforward and simple design. A partition made from kauri wood of the old Cathedral's roof framing separates the priest and penitent, preserving the dignity of the sacrament and providing privacy to the penitent. A light, airy, comfortable, and simple architectural setting for the confessional was designed to achieve a space seen as inviting and a reminder of the Church's healing ministry.

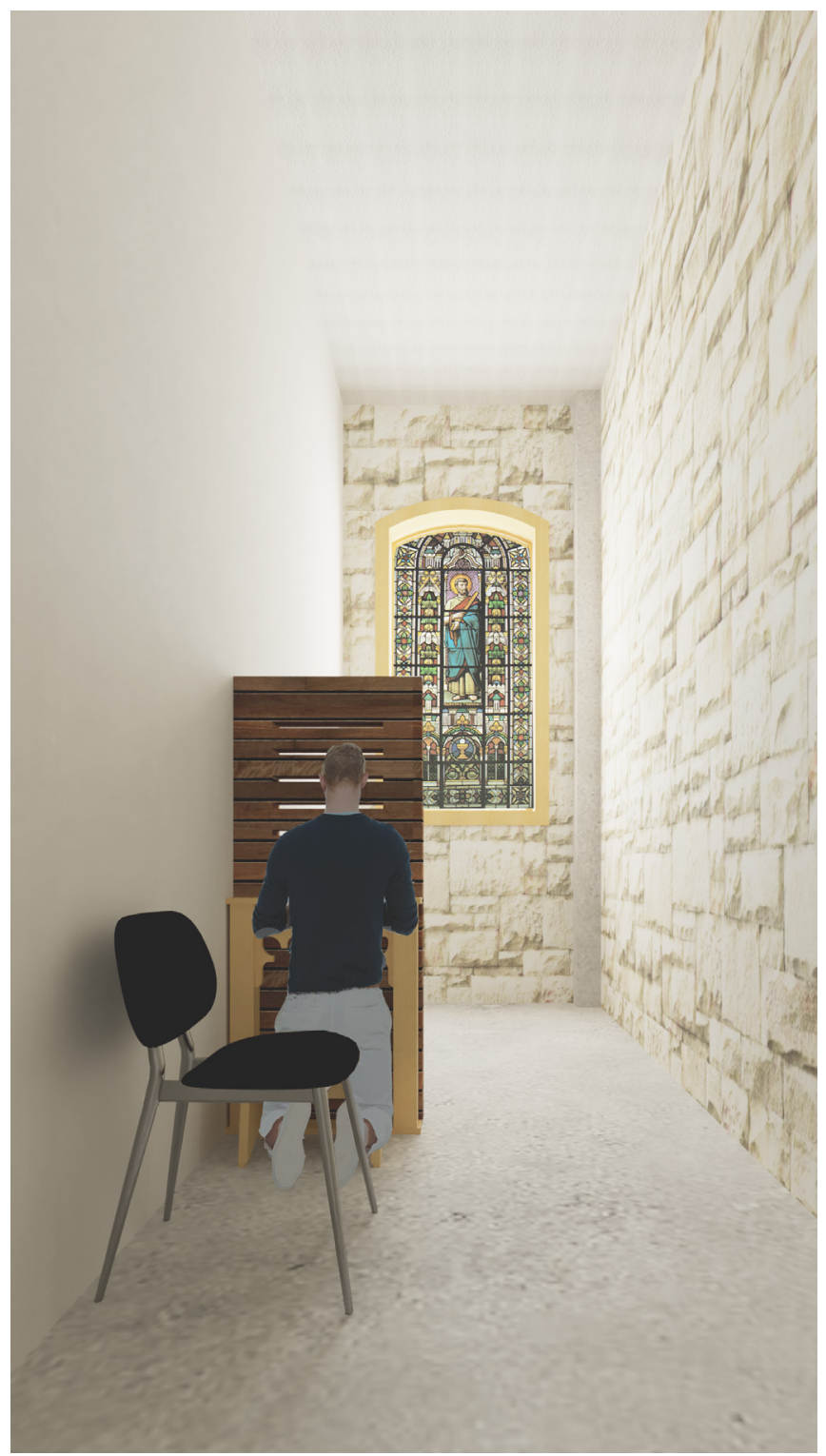




\section{BAPTISTERY}

As baptism is the first and fundamental sacrament in the Church, it was essential to design a baptistery that highlighted its significance. The baptistery's design is a distinct space separated from the rest to give the sacrament its own experience. As the baptistery and baptismal font have always been critical iconographic elements in the Church, the baptistery's form adopts a circular room to emphasise the font at the centre of the space.
The baptistery's design aims to create a space that provides a positive and welcoming experience into the Church, highlighting the beginning of the person's spiritual journey. The high windows surrounding the room and the modern glass dome that pays homage to the old dome of the Catholic Basilica bring an abundance of natural light into the space, representing the warmth and light being received from God when joining the church community.

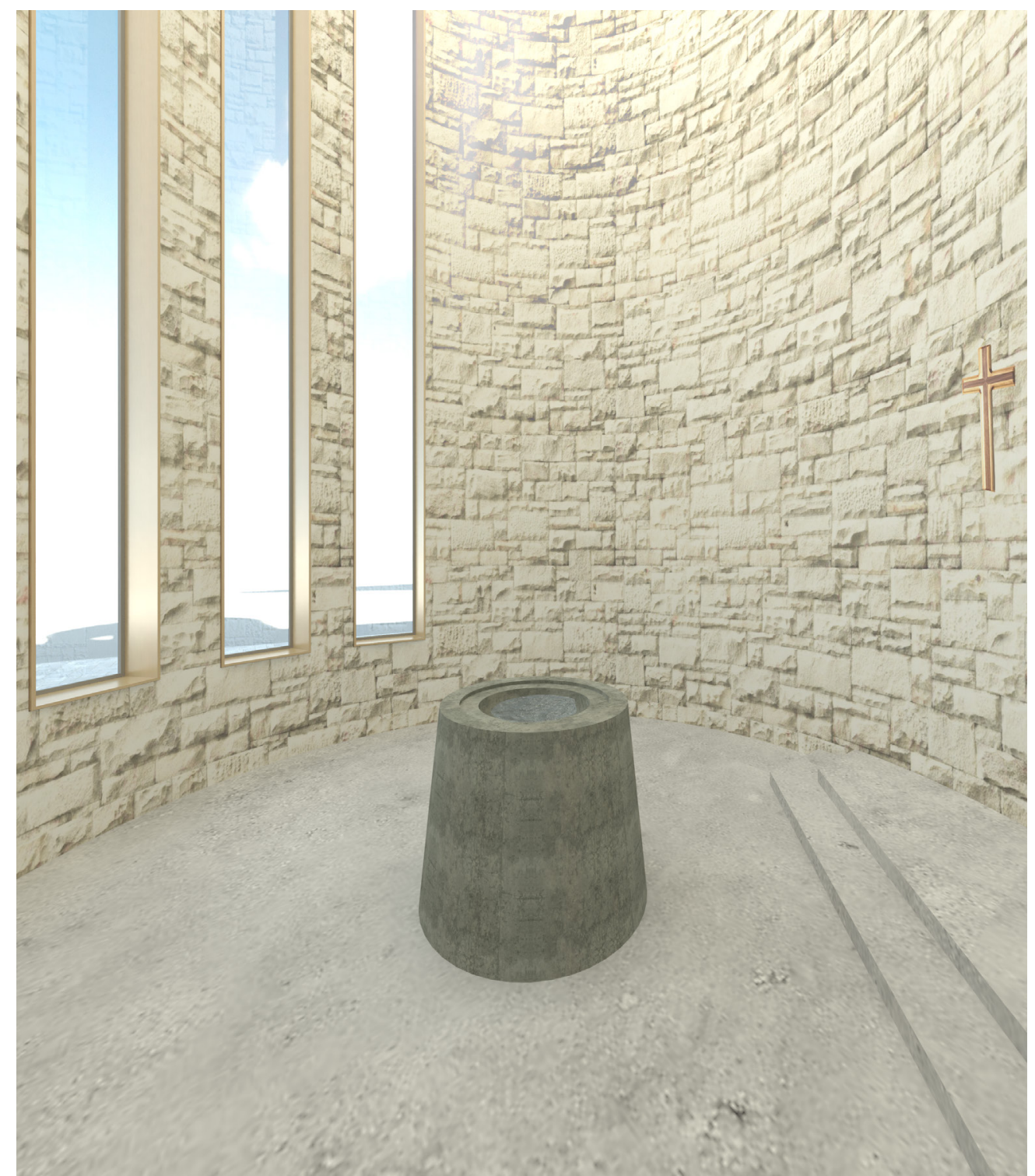

fig10.09 baptistery and baptismal font made from recycled concrete 


\section{SANCTUARY AND NAVE}

The Cathedral's nave is designed to be expansive, able to accommodate large amounts of people at any given time. The clean and straightforward design of the nave allows the occupants to focus on themselves and the liturgy and not be distracted by excessive ornamentation or decoration. The downward slope in the height and building form of the nave directs the occupant's focus towards the sanctuary, emphasising the liturgy's place as the core of the Church.

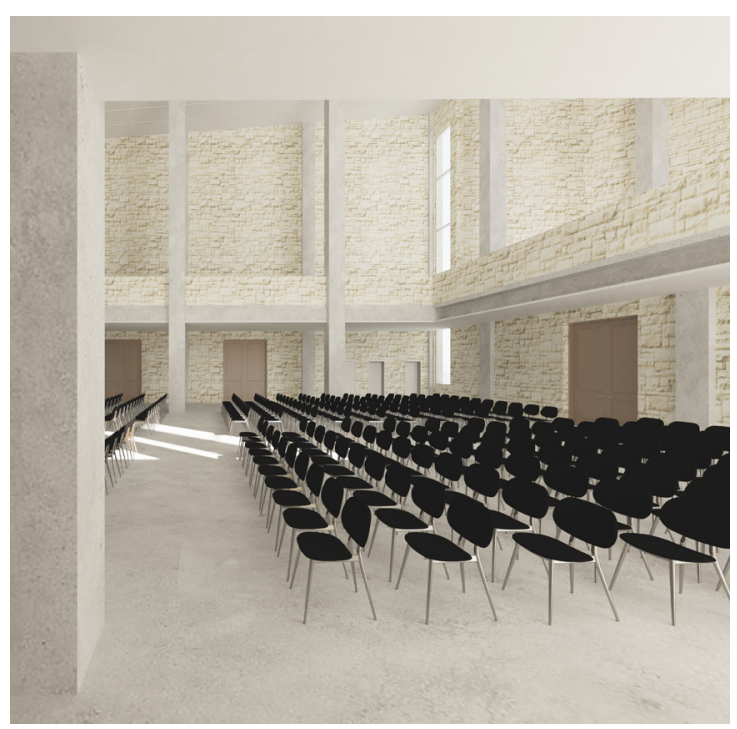

fig10.10 view of back of the nave from the side aisles, showing the simplicity of the design and materiality directing the focus not on decorations and distractions but on the liturgy instead

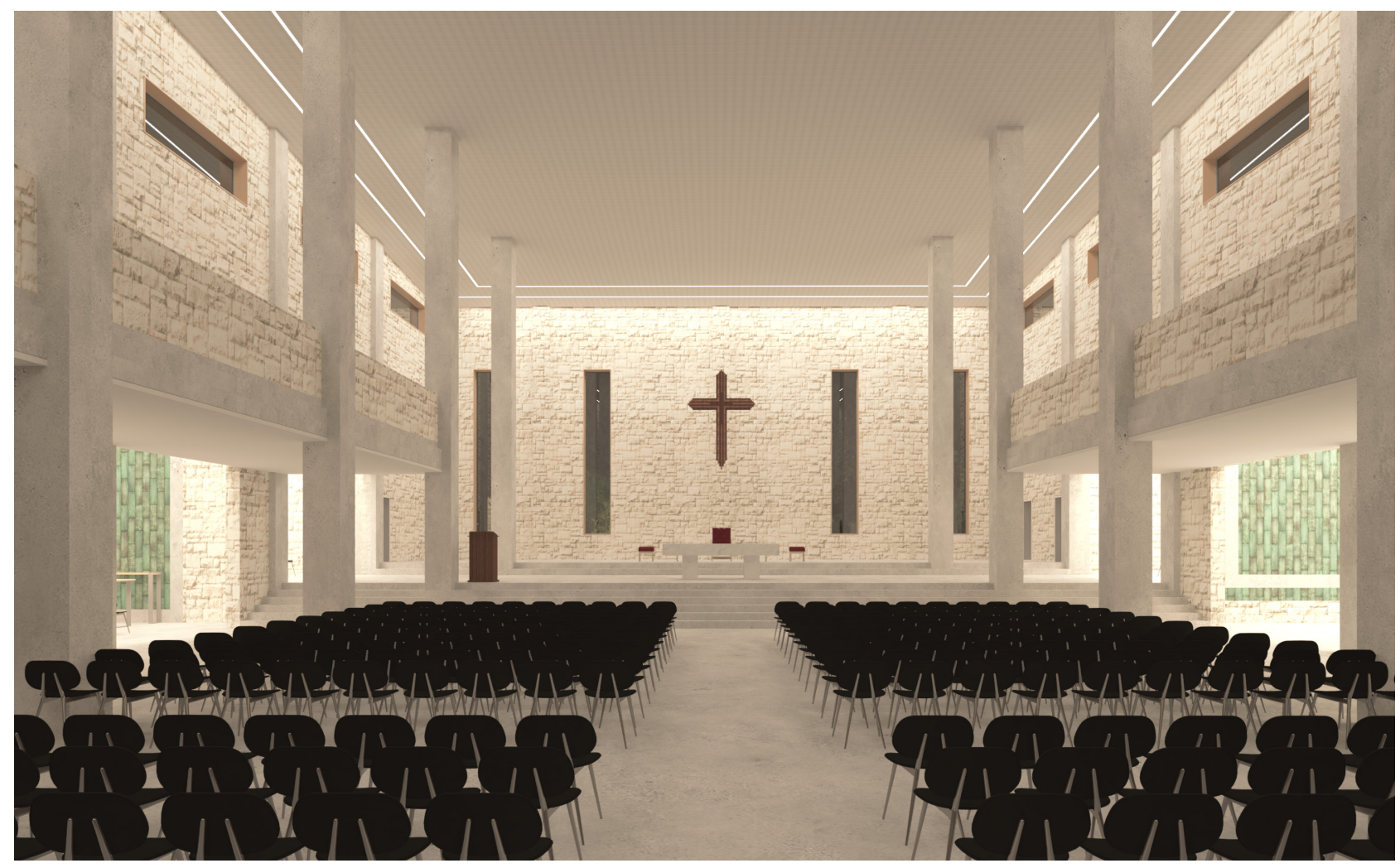

fig10.11 the nave at night void of occupants, capturing the quietness and sacredness of the space 
The nave looks toward and leads up to the sanctuary, where the altar, bishop's throne, and the additional seats for priests are raised to signify their hierarchical importance and role in the Church. It was important for the sanctuary to be raised in the Christchurch Catholic Cathedral design to show the distinct separation between the sacred (the clergy) and the profane (the laity). fig10.12 the sanctuary during mass occupied by its intended users and demonstrating the hierarchal separation between the clergy and the lay through the raised level and the stairs

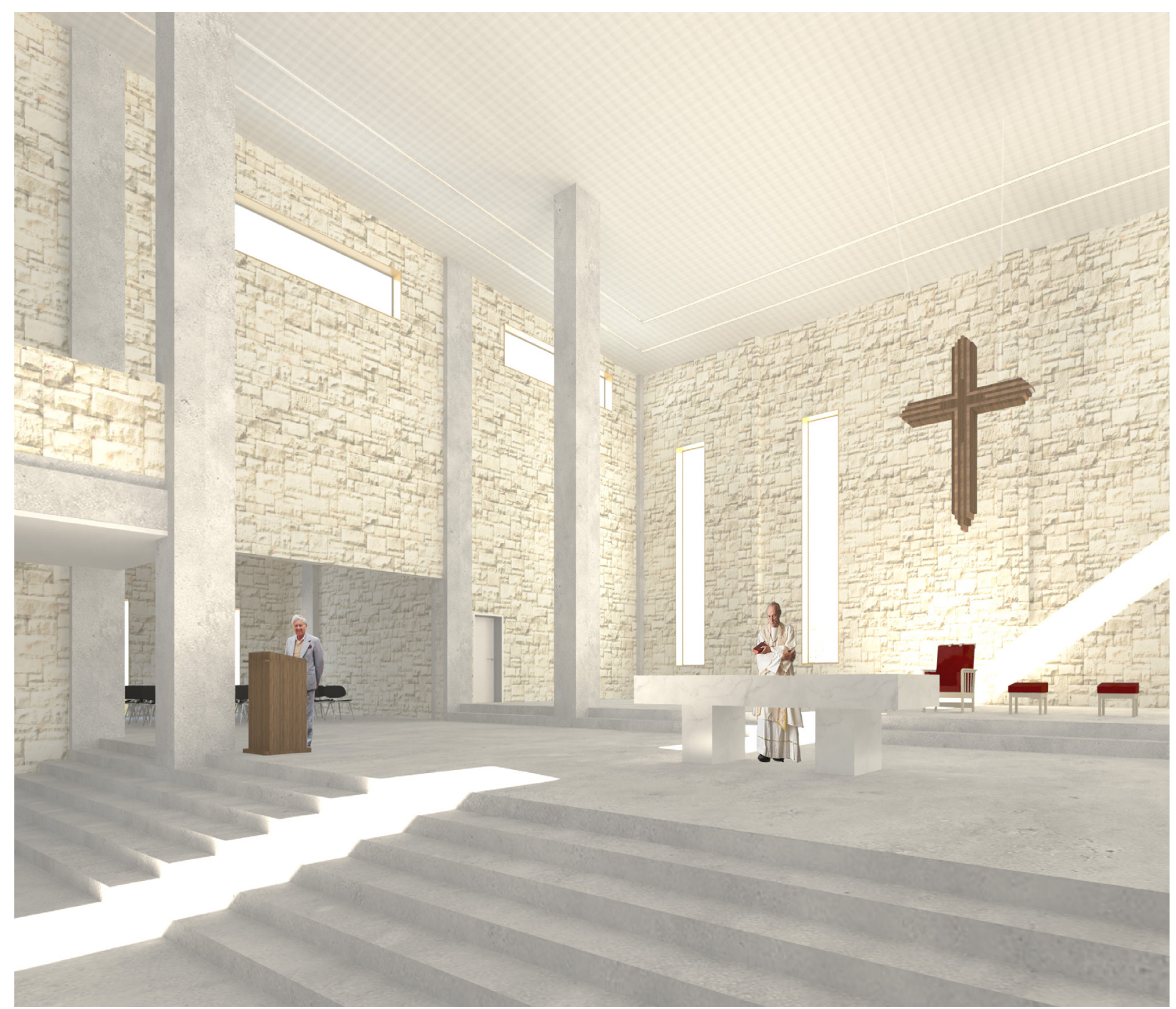




\subsubsection{STRUCTURAL AND MATERIAL CONSIDERATIONS}

This thesis's main focus was the reuse of the old Cathedral's materials to minimise waste and preserve heritage value. The developed design embraces this focus and has sought to reuse as much of the old materials as possible. The different materials and their potential uses were established early on in the design stage to help influence the design's development.
In the Christchurch Catholic Cathedral's developed design, the primary structure, such as the columns, beams, and floor slabs, are reinforced recycled concrete. As discussed in two different case studies in Chapter 2, crushing up the old concrete and turning them into recycled agg regates does not create future structural problems as recycled concrete has the same properties as newly poured concrete. To further emphasise and display the reuse of the old concrete of the Catholic Basilica, the primary structure in the design is left with a smooth concrete finish and provides contrast and variety between the other materials in the architecture.

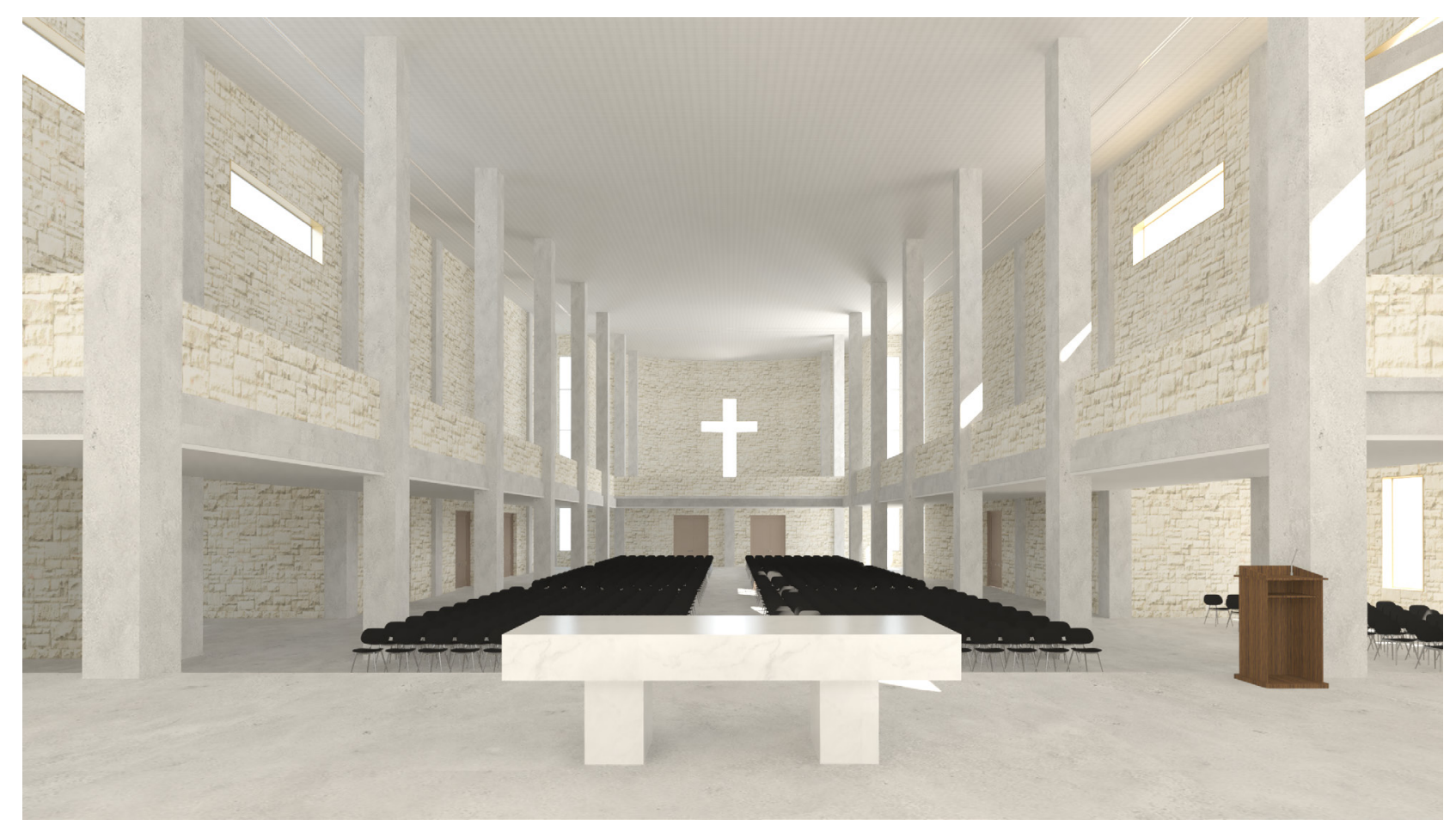

people were deliberately taken out of some of the renders to demonstrate the sheer scale of the space and emphasising that feeling of grandeur, quietness, and sacredness in the space by focusing more about the architectural form than its inhabitants 
The developed design also has walls made from recycled concrete but clad throughout the building with the old Catholic Basilica limestone. By adopting the practice of spolia, the building stones are repurposed and used in the new construction. The stone cladding of the walls emphasises the main idea and goal of the new design where material reuse preserves the Catholic Basilica's heritage value within the materials. The stone cladding throughout the building makes it known that the architecture is made from historical materials and serves as a prominent reminder that the Cathedral already carries history within its materials and that new life can be brought back into old things.

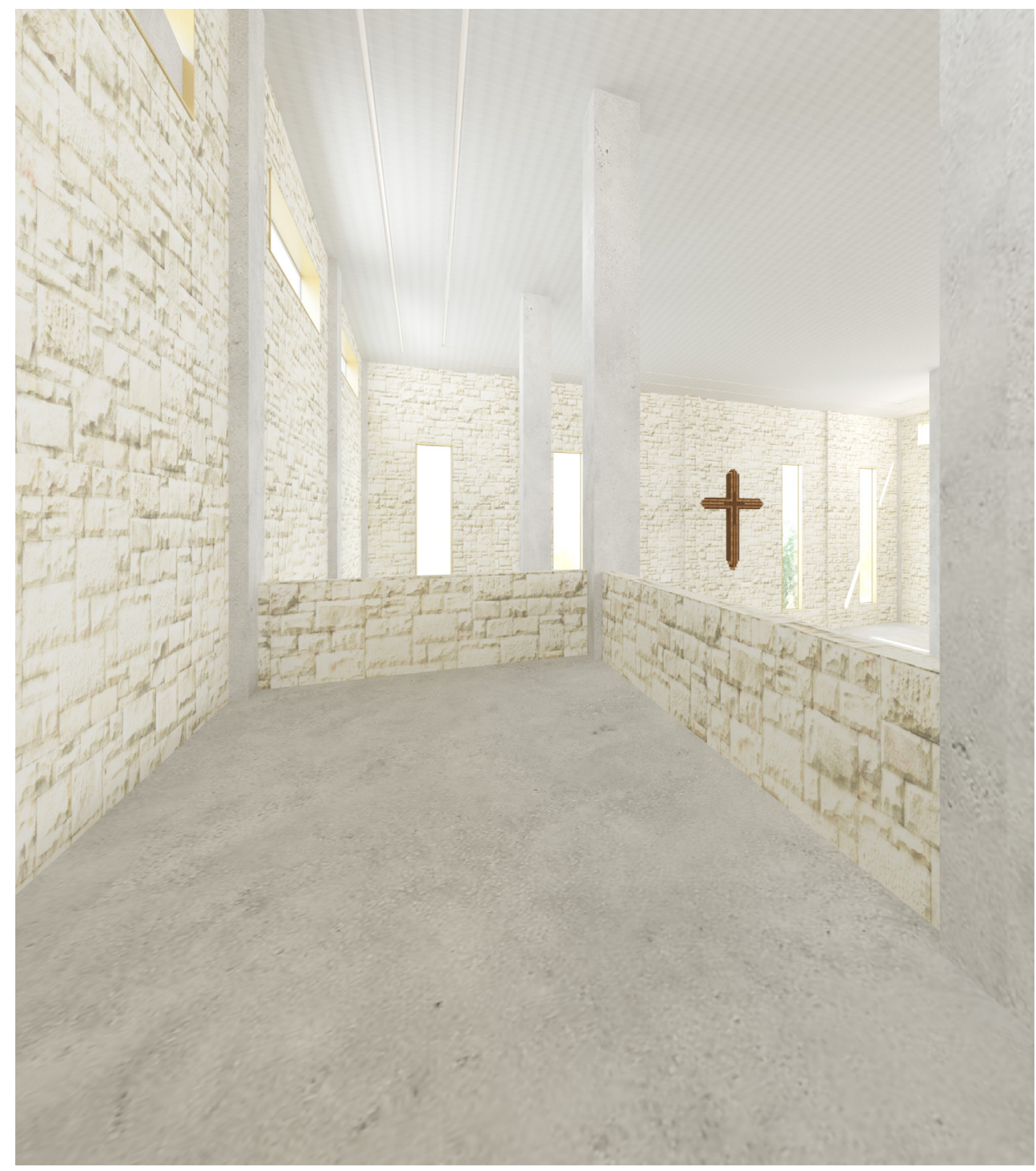

fig10.14 view from upper gallery with white pressed zinc ceiling and the crucifix in the background. void of occupants, this render focuses on the materiality, particularly the heavy reuse of stone and concrete throughout the building emphasising the focus on material reuse to bring history into the building 
While stone is the primary material used for cladding, some spaces in the design are instead clad in metal. Green copper panels made from the old copper roof of the dome are reused as cladding for feature walls in the side and memorial chapels, and the pressed zinc sheets are also salvaged and reused as the ceiling for the nave. The pressed zinc sheets are painted white to keep the space bright and to help reflect the natural light around.

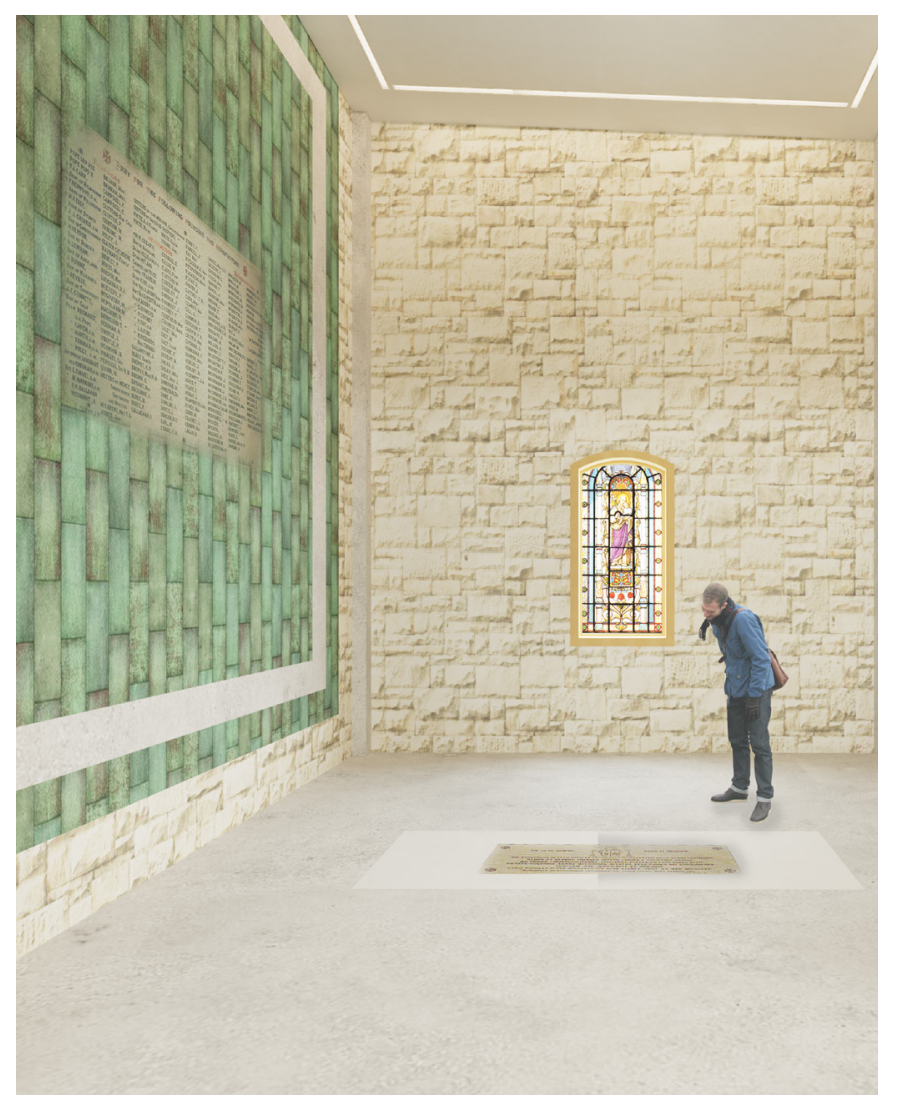

fig10.16 memorial chapel, where bishop grimes will be buried. feature wall made from copper panels of the old dome providing the space and bishop grimes a memorable piece of the old cathedral he built and served in. the list of benefactors of the old cathedral also hangs over on the wall

because of the simplicity of the design and deliberate lack of decoration in the architecture to achieve the objective of creating a building that does not distract from the celebration of the liturgy, as some people are included in a few renders to show how they would occupy the space, it demonstrates how the occupants themselves become the ornamentation in the architectural space
While the developed design mostly uses new large windows, some of the stainedglass windows able to be salvaged from the old Cathedral are also included in the design. The reuse of the stained-glass windows alongside the more modern windows makes it evident that the stained-glass are of significant heritage value. They were reused themselves in the old Catholic Basilica construction and were originally from the wooden church that existed before the Cathedral of the Blessed Sacrament. By reusing these stained-glass windows and including them in the design, it acknowledges the Church's history and pays tribute to the very beginning of the Catholic community in Christchurch.

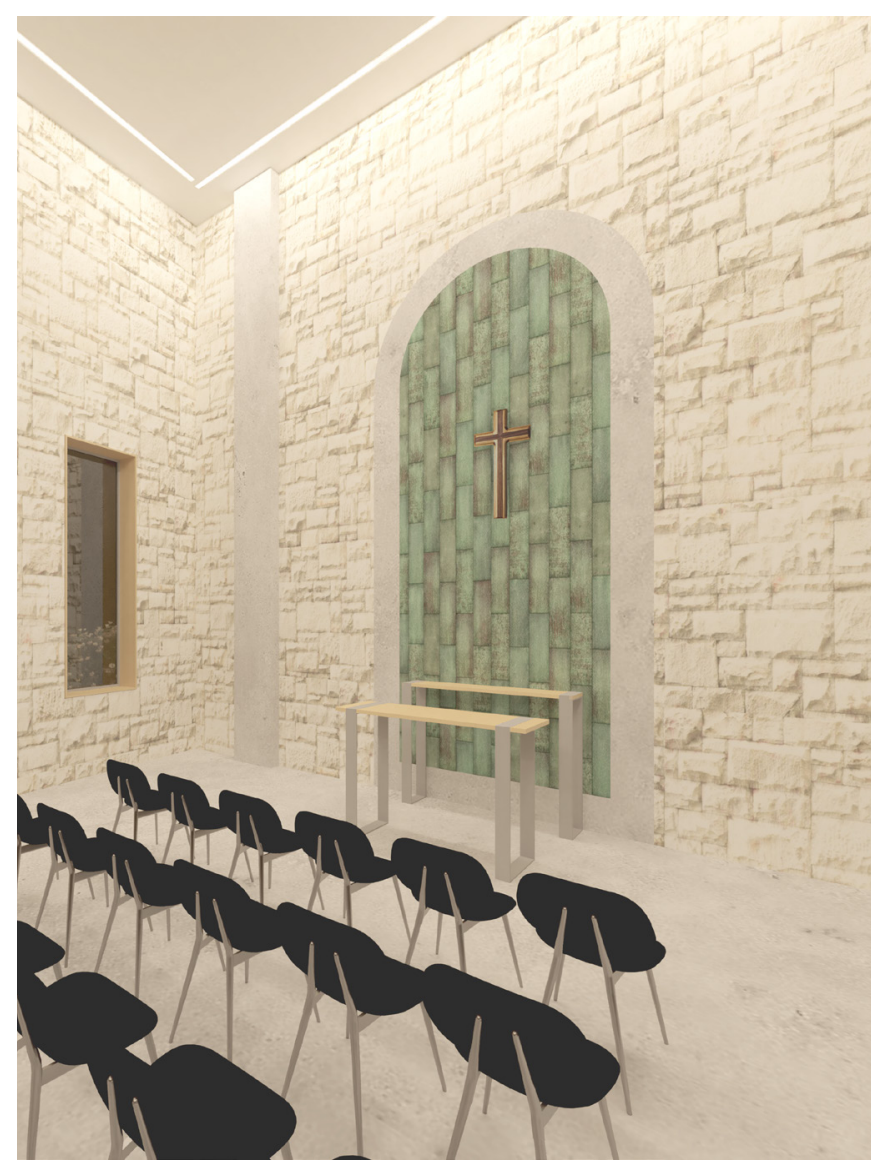

fig10.15 side chapel, providing a space for smaller liturgies or private prayer with a copper feature wall as an architectural element and backdrop to the small altar 
In the entrance/narthex in the developed design of the Cathedral, the ceiling is lined with kauri timber slats from the old roof framing of the Catholic Basilica. This architectural feature makes the space a lot more inviting and less cold by adding texture and colour to the space. The timber slats are a nice contrast and break between the concrete and stone materials used throughout the building. fig10.17 narthex and entrance of the cathedral, reused wood is used as timber slats on the ceiling to bring more colour and make the space more modern and inviting

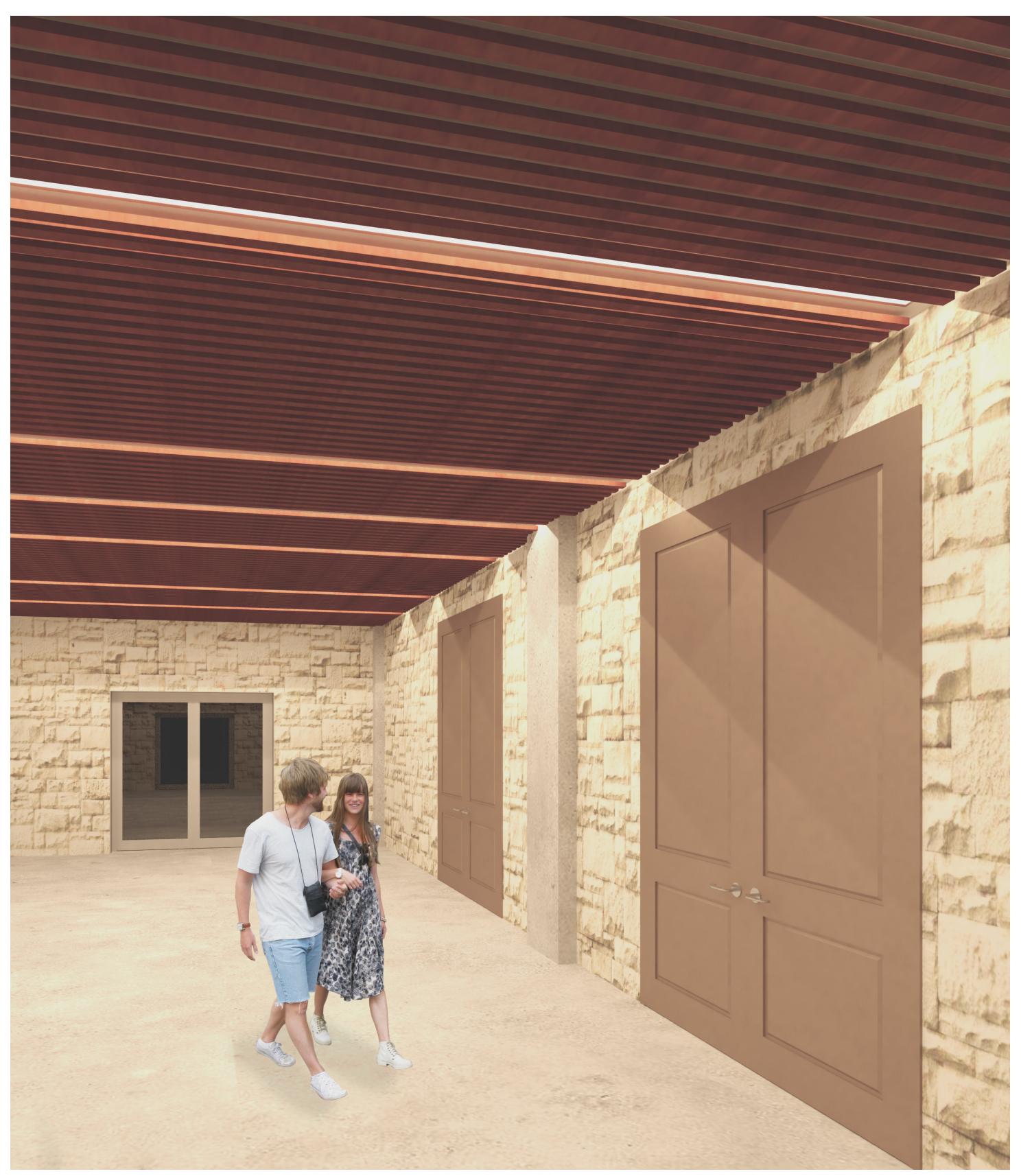


The old Catholic Basilica's ionic columns are also considered in the developed design of the new Cathedral. While these columns are not used structurally in the architecture, they are used as pillars for the stations of the cross garden at the back of the Cathedral. The ionic columns provide history and height to the architecture's surrounding landscape and create a space that allows the story of Jesus' crucifixion to be told.

Overall, the structural and material considerations throughout the design, particularly the reuse of materials, bring history to the site and allow the materials to tell the Cathedral's past in built form. fig10.18 stations of the cross garden, reusing the original stations of the cross from the old cathedral by artist llew summers and fixing them onto limestone blocks

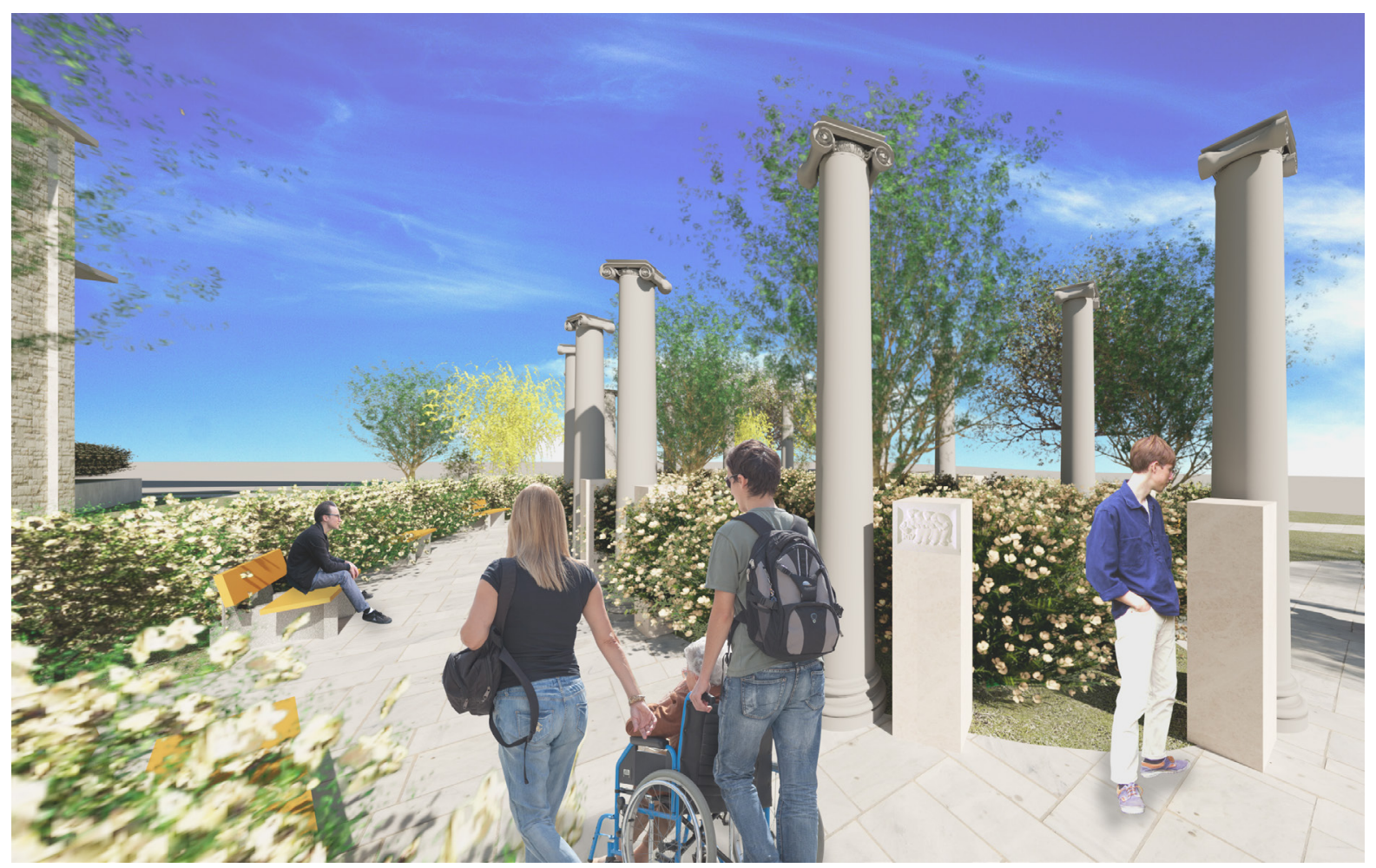




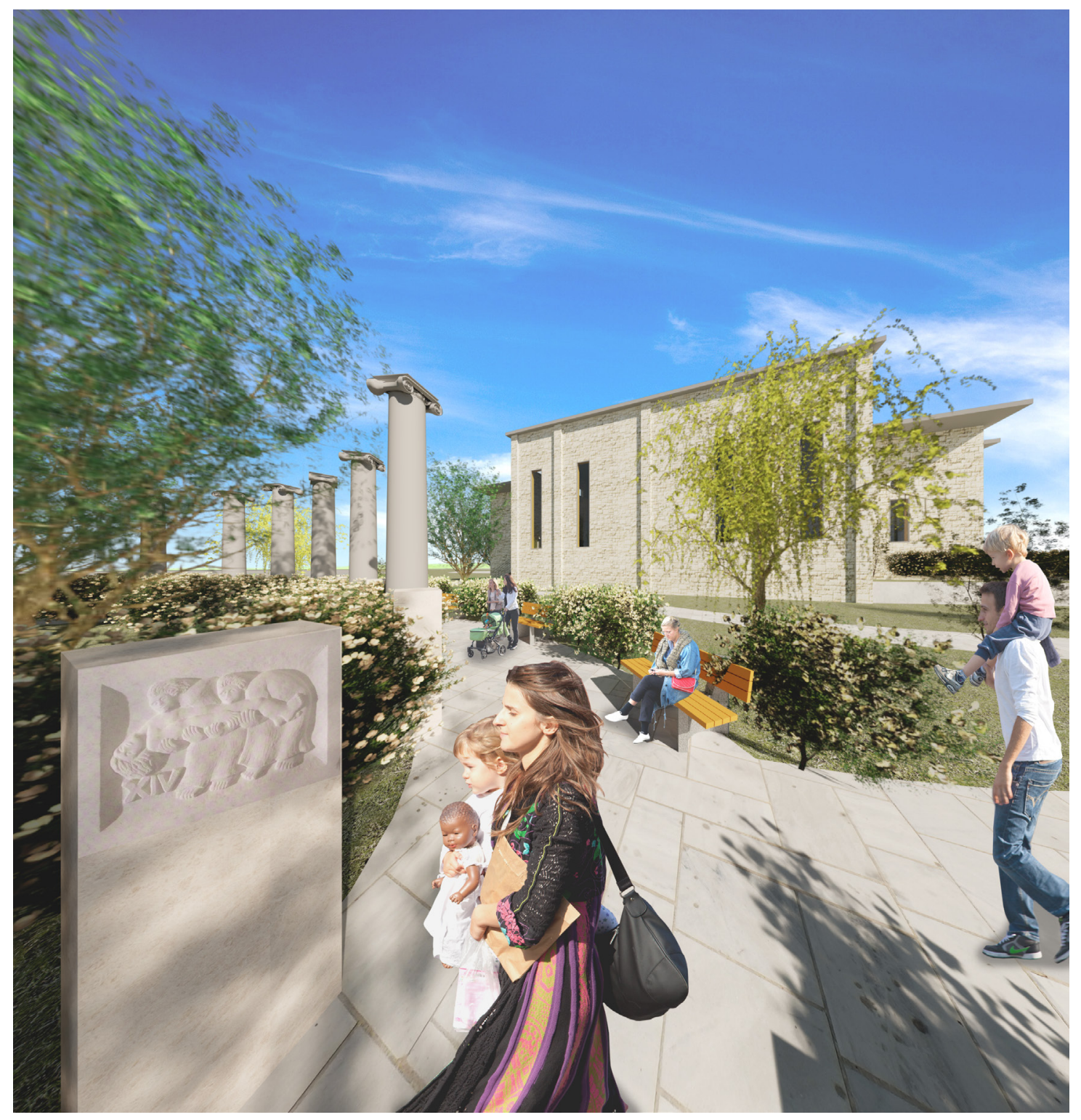

fig10.19 stations of the cross garden, using ionic columns as markers/pillars next to llew summer's original stations of the cross 


\subsubsection{ARCHITECTURAL INTENT}

The intention of this thesis was to create a developed design of the new Christchurch Catholic Cathedral for a community that has lost its Cathedral due to the Christchurch Earthquakes and demolition. The Catholic community in Christchurch needs a space that can act as the home base for their Diocese that is suitable to accommodate many people. The new Cathedral's developed design intends to bring the community back together after years of not having a stable architectural base. The developed design intends to be a place for individual prayer and mass gatherings to celebrate the liturgy.

Overall, the building's developed design aims to evoke a feeling of simplicity, elegance, and transcendence within the architecture where the occupant can focus on the liturgy and their spiritual journey and not be distracted. The architecture intends to be a safe space for the Catholic community and wants people to feel invited and to have a positive experience in the building. The overall building design and form use the building's height as a tool to evoke different feelings in the space. The downward slope in the nave directs the occupant's focus towards the sanctuary, the most sacred space in the Cathedral, encourages prayer, creates a sense of the sacred, and reflects the holiness of the holy mysteries and sacraments that the design aims to achieve.

The developed design intends to reuse the materials of the old Catholic Basilica in the new Cathedral. Material reuse intends to create an architecture that is new, functional, and appropriate to its setting that respects the past and the history of the building and the Christchurch Diocese. This thesis focuses on material reuse to minimise the construction and demolition waste from the industry to the landfills. It also shows that material reuse is a valid preservation method for heritage buildings showing that heritage value and significance does not need to be lost when total demolition of a heritage-significant building is the only option.

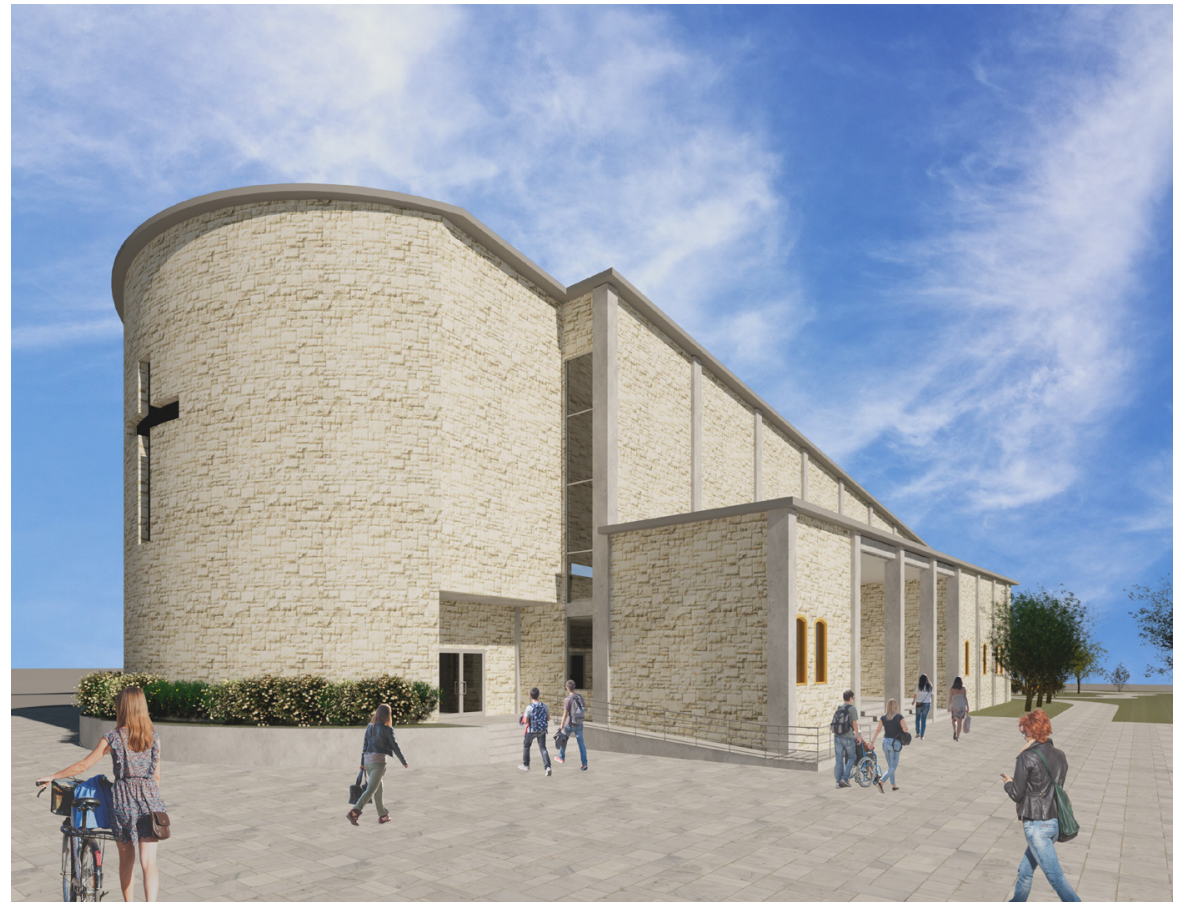

fig10.20 south-east exterior view of the cathedral showing the heavy use of stone in the design and showing the sloping architectural form 


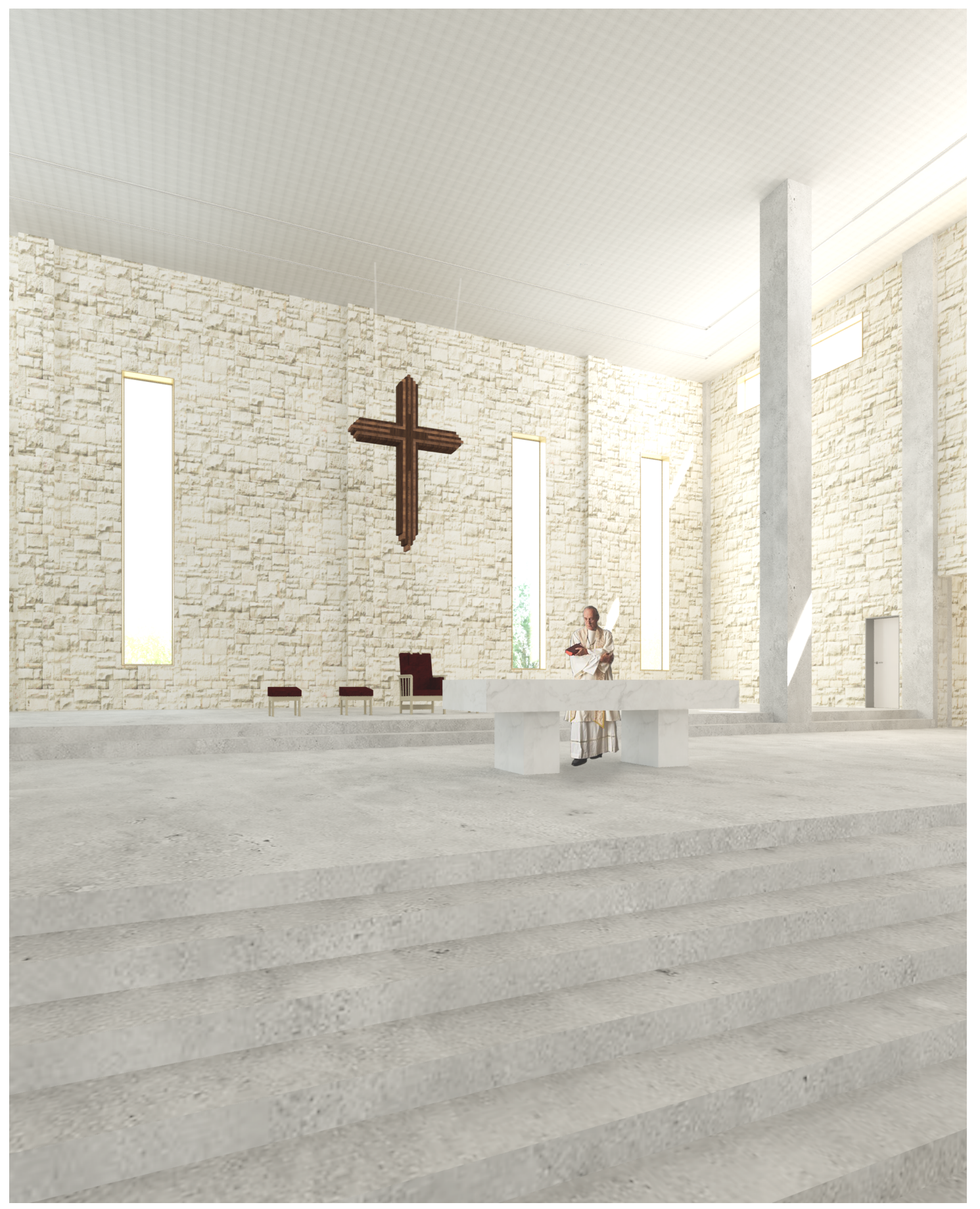

fig10.21 the sanctuary is an expansive and sacred space dedicated to the bishops and priests and the celebration of the liturgy 

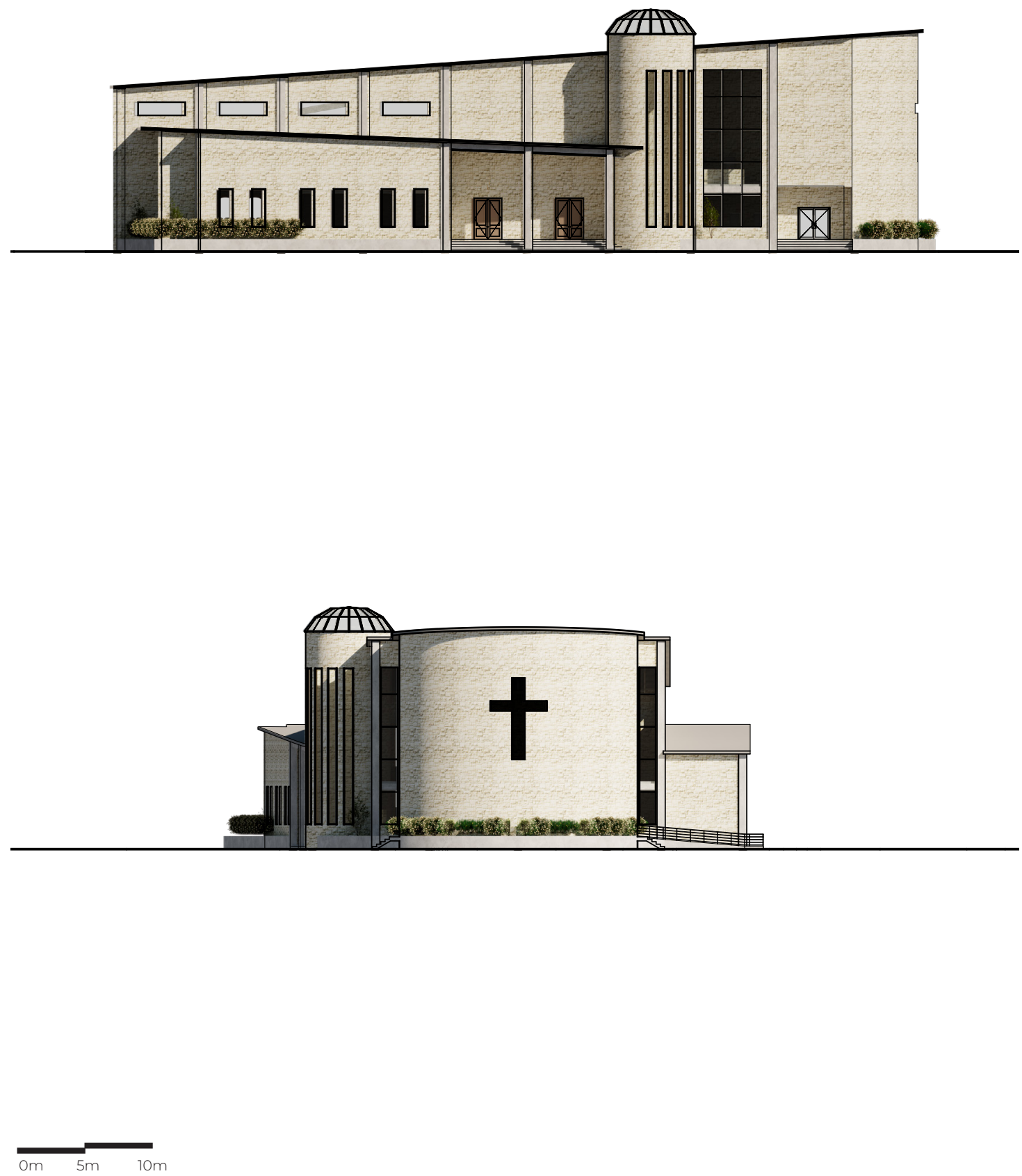

fig10.22 west elevation

fig10.23 south elevation 

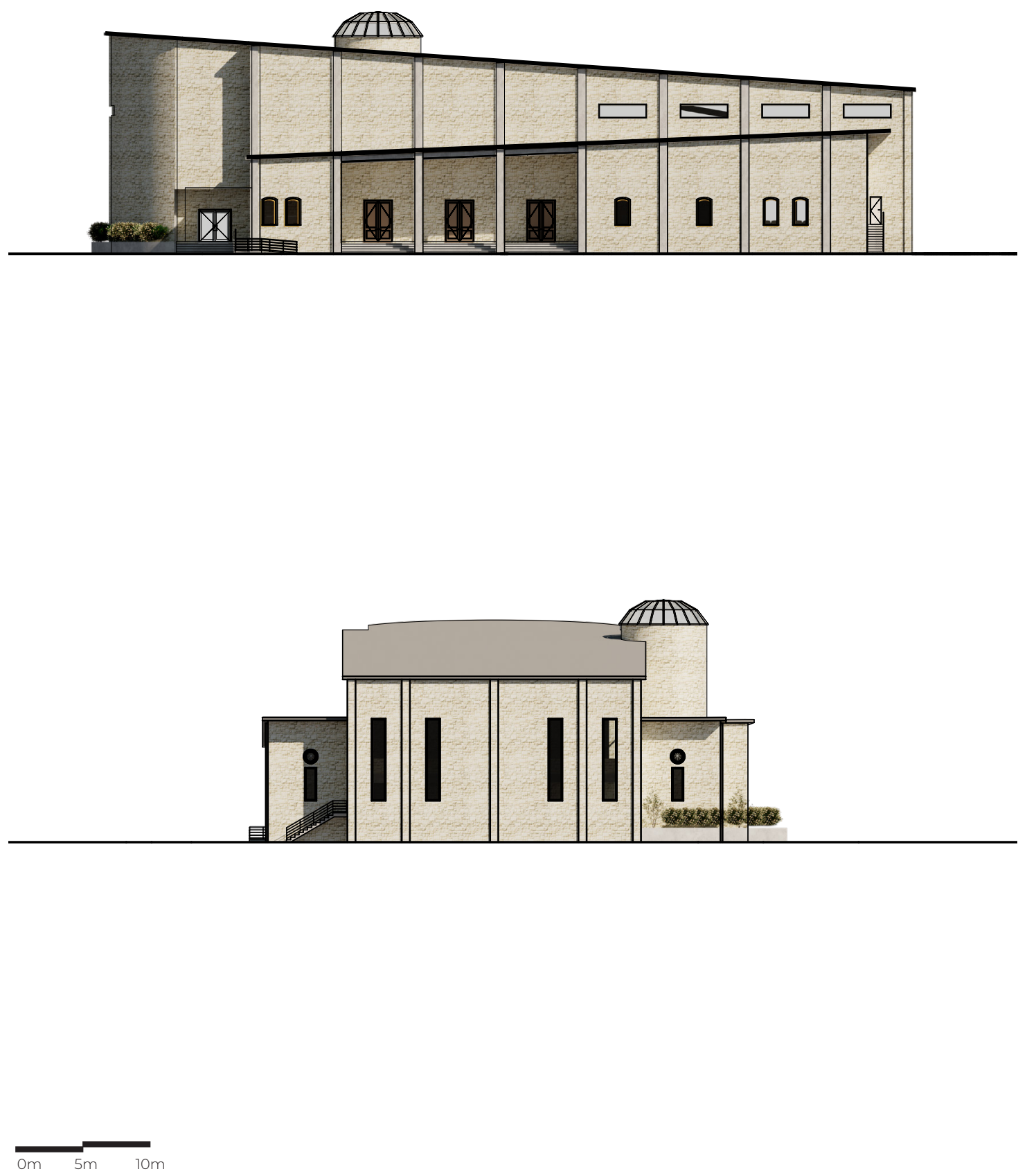

fig10.24 east elevation

fig10.25 north elevation 

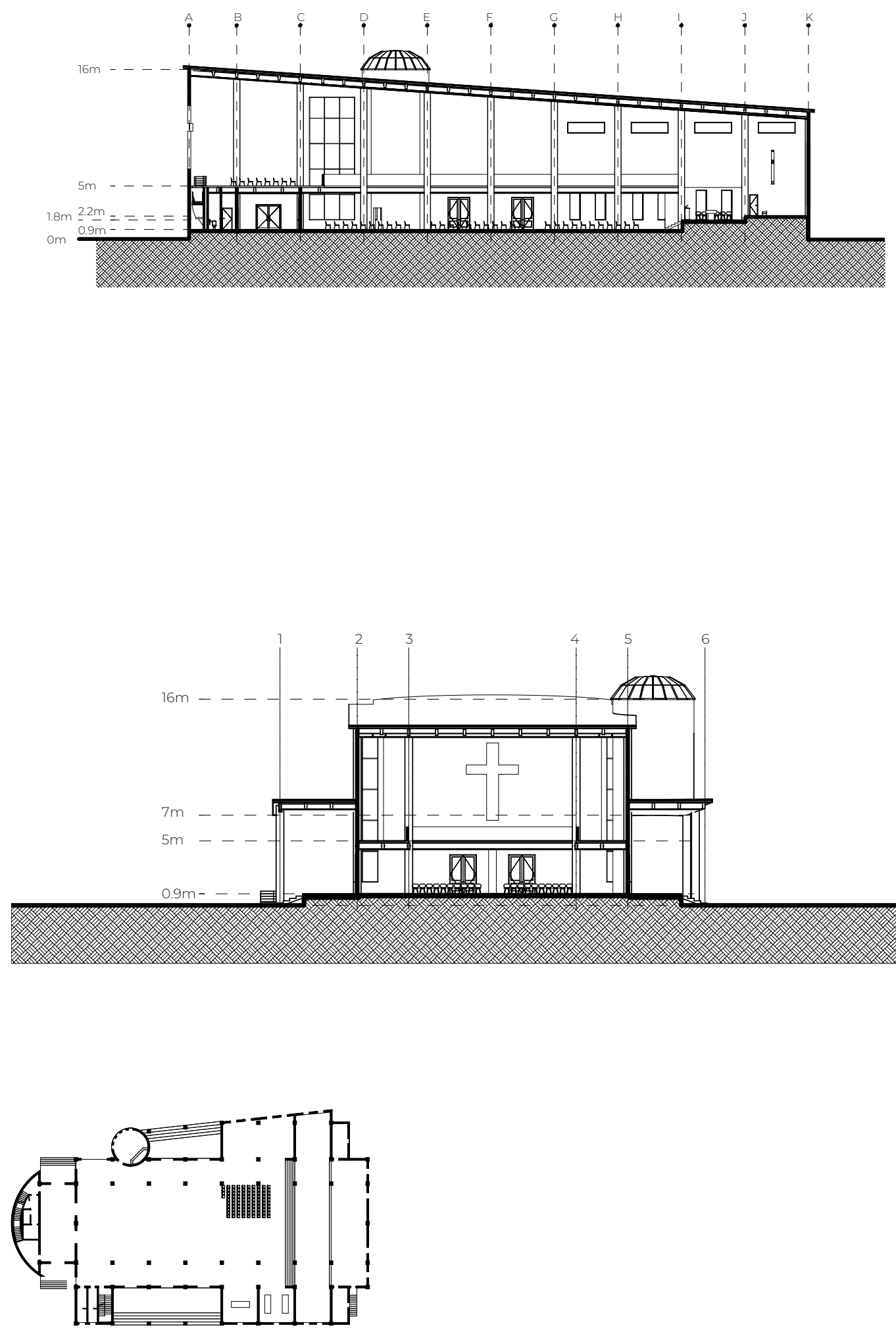


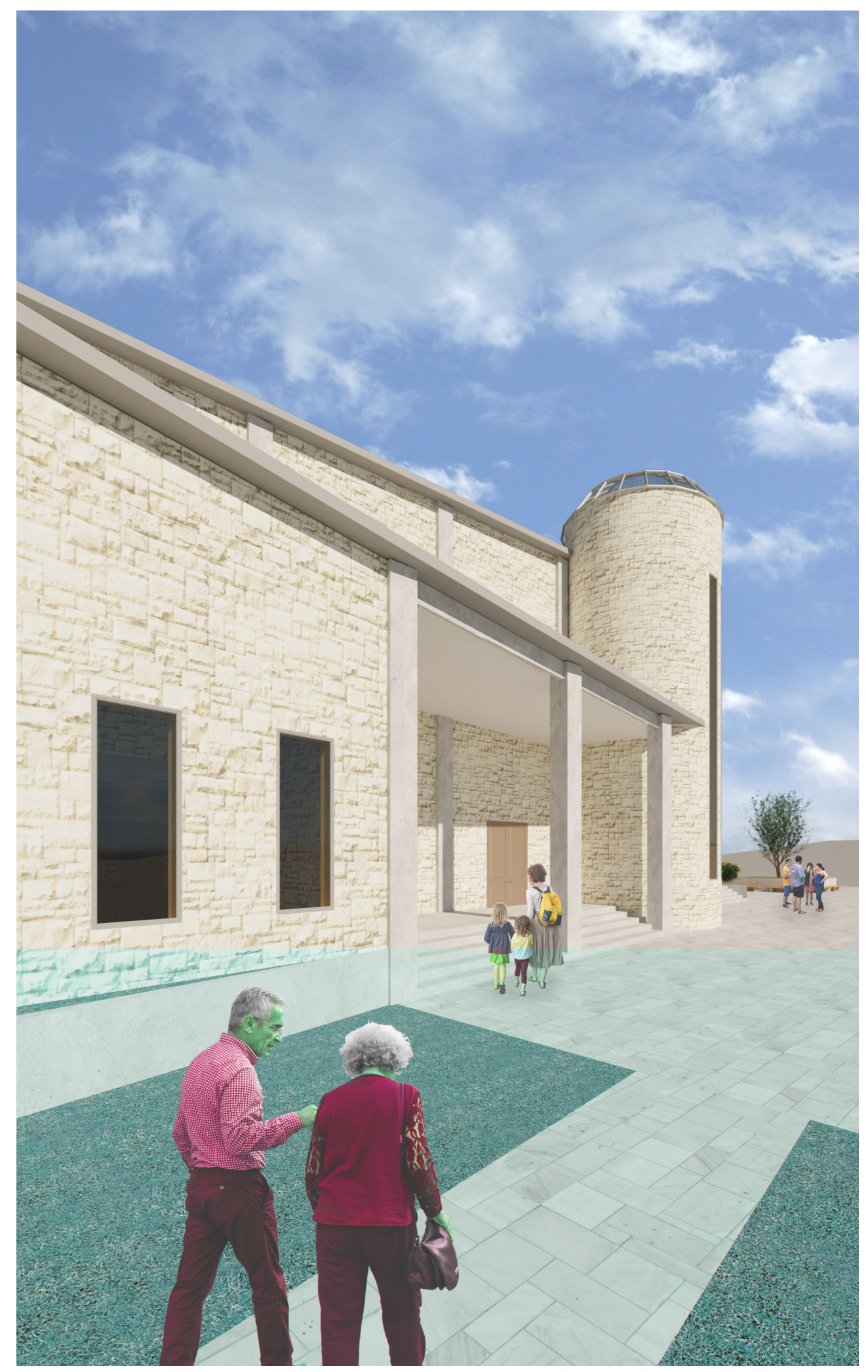

fig10.28 exterior shot of the west side of the cathedral showing the sheer scale and height of the building 


\section{CHAPTER 11}

CONCLUSION 
Christchurch was left to pick itself back up from the ruins left by the 2011 Earthquakes. The majority of the buildings in the city centre were lost and demolished due to their structural instability. This includes many of the city's heritage buildings, resulting in Christchurch losing much of its architectural history. As the 2011 Christchurch Earthquakes left the city in a state of repair, it raises the question of what happens to the heritage significance and the construction and demolition waste for those heritage buildings with no other options than total demolition.

Much of New Zealand's waste problem lies in the construction industry, where construction and demolition waste covers over $50 \%$ of the country's total waste. $81 \%$ of this are contributed by timber, concrete, and plasterboard. When buildings, both heritage and non-heritage, have no option other than total demolition, especially after natural disasters like the Christchurch Earthquakes, more waste than average is contributed to landfills. A solution to drastically minimise the construction and demolition waste the construction industry is currently contributing to the landfills needs to be established as soon as possible. The industry has a significant contribution to the climate emergency the earth is currently facing. In the case of heritage buildings, a solution to minimise the waste and preserve the heritage value and history of the heritage-significant buildings also needs to be established.

Material reuse is the key to both the waste and heritage problems outlined. While the heritage sector has outdated views on material reuse, research done in this thesis identifies material reuse as a genuine mode of preservation practice. This thesis shows how valuable material reuse could be if implemented. As it is inevitable for heritage buildings to be demolished and lost, it is shown that the lifecycle of heritage-significant buildings does not have to end in demolition and that there is a potential to preserve history through the reuse of materials. By salvaging construction materials during demolition and reusing them for a new build, this is a solution to minimising the waste and how heritage value and history of the demolished building could live on.

This research portfolio has aimed to create a design with its focus on material reuse to minimise waste and preserve heritage, using the Cathedral of the Blessed Sacrament as a vessel. With the current plan for demolition and new build on an entirely new site and the amount of history and value stored within the Catholic Basilica materials, the Cathedral is a great design opportunity and brief for this thesis. This thesis does not suggest that the design is of/has heritage significance or status. It instead expresses that the new design is built from heritage significant materials and has history stored within the architecture materials to preserve the old building's history in a new form.

The final Cathedral design proposed in this thesis was carefully researched and planned for, following design guidelines and suggestions from the Church to achieve a design that was both traditional and modern at the same time. History and historical precedent are deeply rooted in the Cathedral layout and within the materiality of the building. The design aimed to create a simple and elegant Cathedral focused on the fundamentals of Church liturgy and create an architecture that respected the past while creating something new, functional, and appropriate to its setting. The graceful and simplistic design allows its occupants to focus on the Church's function and the feelings evoked within without getting distracted by the clutter of ornamentation. The success of the design's elegance lies in simplicity, where there are subtle tributes to symbolism and history via the building form, materiality, and other architectural features. 
REFERENCES 
Arlotta, A. I. (2019). Locating heritage value in building material reuse. Journal of Cultural Heritage Management and Sustainable Development, 6-15.

Bahamon, A., \& Sanjines, M. C. (2008). Rematerial from Waste to Architecture. Barcelona: Parramon Ediciones.

BFT International. (2015, April). Pilot project with recycled aggregates. Retrieved July 15, 2020, from https://www.bftinternational.com/en/artikel/bft_Pilot_project_with_recycled_aggregates_2312967.ht $\mathrm{ml}$

BRANZ. (2020). Benefits of reducing waste. Retrieved from BRANZ: https://www.branz.co.nz/sustainable-building/reducing-buildingwaste/rebri/benefits/

BRANZ. (2020). Minimising Waste. Retrieved June 25, 2020, from http://www.level.org.nz/material-use/minimising-waste/

BRANZ. (2020). Reducing building material waste. Retrieved from BRANZ: https://www.branz.co.nz/sustainable-building/reducing-building-waste/

BRANZ. (2020). Reuse and Recycling. Retrieved July 15, 2020, from http://www.level.org.nz/material-use/minimising-waste/reuse-and-recycling/

Bullen, P., \& Love, P. (2011). A new future for the past: a model for adaptive reuse decisionmaking. Built Environment Project and Asset Management, 7(1), 32-44.

Erimtan Archaeology And Arts Museum. (2020). Erimtan Archaeology and Arts Museum. Retrieved from Erimtan Archaeology and Arts Museum: https://erimtanmuseum.org/en/museum

European Commission. (2017). Using recycled concrete in the construction of new buildings. GPP In Practice(75), 1-3.

European Commission. (2019). Construction and Demolition Waste (CDW). Retrieved June 26, 2020, from https://ec.europa.eu/environment/waste/construction_demolition.htm

Feireiss, L., \& Klanten, R. (2010). Closer to God: religious architecture and sacred spaces. Berlin: Gestalten.

Gehrig, S. (2019). A low carbon, circular economy approach to concrete procurement. Retrieved from GPP Good Practice: https://ec.europa.eu/environment/gpp/pdf/news_alert/Issue_88_Case_Study_168_Zu rich.pdf 
Greater London Authority. (2019). Design for a Circular Economy: A Built Environment for All Londoners. London: Greater London Authority.

Hanrahan, M. J. (2004). 'A Suitable Temple': A History of the Cathedral of the Blessed Sacrament, Christchurch, New Zealand 1905-2005. Ashburton: Cathedral of the Blessed Sacrament Centennial Committee.

Heritage New Zealand Pouhere Taonga. (2020). Introduction to Heritage New Zealand Pouhere Taonga. Retrieved August 1, 2020, from https://www.heritage.org.nz/aboutus/introduction

Heritage New Zealand Pouhere Taonga. (2021, Februrary 25). Cathedral of the Blessed Sacrament (Catholic). Retrieved from Heritage New Zealand Pouhere Taonga: https://www.heritage.org.nz/the-list/details/47

Holtorf, C. (2013). On Pastness: A Reconsideration of Materiality in Archaeological Object Authenticity. Anthropological Quarterly, 86(2), 427-443.

ICOMOS New Zealand. (2010). ICOMOS New Zealand Charter. Retrieved from http://icomos.org.nz/wp-content/uploads/2016/08/NZ_Charter.pdf

Interrobang. (2020). Ilford Community Market. Retrieved July 10, 2020, from https://www.interrobang.london/projects/ilford-community-market/

Jäger, K. (2016). German Environmental Award goes to concrete recycling. Retrieved July 2, 2020, from https://www.dw.com/en/german-environmental-award-goes-toconcrete-recycling/a-36191085

Jones, S. (2009). Experiencing authenticity at heritage sites: Some implications for heritage management and conservation. Conservation and Management of Archaeological Sites, 77(2), 133-147.

Jones, S. (2010). Negotiating Authentic Objects and Authentic Selves: Beyond the Deconstruction of Authenticity. Journal of Material Culture, 15(2), 181-203.

Jones, S. C., \& Holden, J. (2008). It's a Material World: Caring for the Public Realm. London: Demos.

Kalakoski, I., \& Huuhka, S. (2018). Spolia revisited and extended: The potential for contemporary architecture. Journal of Material Culture, 23(2), 187-213.

Kinney, D. (2011). Ancient Gems in the Middle Ages: Riches and Ready-mades. In Reuse Value: Spolia and Appropriation in Art and Architecture from Constantine to Sherrie Levine (pp. 97-120). Farnham: Ashgate Publishing Limited.

Meyer, U. (2019, June 6). Spolia in the Wall. Retrieved from World-Architects: https://www.world-architects.com/en/architecture-news/reviews/spolia-in-the-wall 
Ministry for Culture and Heritage. (2020, October 6). Christchurch earthquake kills 785. Retrieved from New Zealand History: https://nzhistory.govt.nz/page/christchurchearthquake-kills-185

Ministry for the Environment. (1997). New Zealand's Cultural Heritage. Retrieved August 1, 2020, from https:/www.mfe.govt.nz/publications/environmental-reporting/statenew-zealand\%E2\%80\%99s-environment-1997-chapter-two-place-and

Ministry for the Environment. (2007). Targets in the New Zealand Waste Strategy. Wellington: Publication number: 802 .

Ministry for the Environment. (2010, October 12). Construction and demolition waste: how to manage responsibly. Retrieved from Ministry for the Environment: https://web.archive.org/web/20150114155052/http:/mfe.govt.nz/issues/waste/construc tion-demo/index.html

Mısırlısoy, D., \& Günçe, K. (2016). Adaptive reuse strategies for heritage buildings: A holistic approach. Sustainable Cities and Society, 26, 91-98.

Pallister, J. (2015). Sacred Spaces: Contemporary Religious Architecture. London: Phaidon Press Limited.

Radio New Zealand. (2019, December 7). Radio New Zealand. Retrieved from New Catholic cathedral part of $\$ 500 \mathrm{~m}$ Christchurch development: https://www.rnz.co.nz/news/national/405016/new-catholic-cathedral-part-of-500mchristchurch-development

Schloeder, S. J. (1998). Architecture in Communiion: Implementing the Second Vatican Council through Liturgy and Architecture. San Francisco: Ignatius Press.

Taylor, J. (2015). Embodiment unbound: Moving beyond divisions in the understanding and practice of heritage conservation. Studies in Conservation, 60(1), 65-77. 
LIST OF FIGURES 
fig1.01 diagram of thesis aims and objectives - Authors Own

fig1.02 methodology diagram - Authors Own

cover image and fig2.01 cathedral of the blessed sacrament destruction after 2011 christchurch earthquake Wethey, D. (2011, February 24). Scenes of destruction. Retrieved from Otago Daily Times: https://www.odt.co.nz/ slideshow-section/special-news/scenes-destruction

fig2.02 cathedral of the blessed sacrament - Lovell-Smith, M. (2001, September 9). Cathedral of the Blessed Sacrament (Catholic). Retrieved from Heritage New Zealand Pouhere Taonga: https://www.heritage.org.nz/the-list/ details/47

fig2.03 wellington sacred heart cathedral - Collins, C. (2015). Cathedral of the Sacred Heart. Retrieved from Wellington City Heritage: https://wellingtoncityheritage.org.nz/buildings/1-150/146-cathedral-of-the-sacred-heart fig2.04 francis petre's sketched suggestion of the layout - Christchurch Diocese Archives. (1899). Letter from Petre to Grimes February 6, 1899.

fig2.05 the walls were finished with mount somers stone to windowsill height and oamaru stone above that point - Christchurch Diocese Archives. (1902). Bishop Grimes and a group of onlookers watched from the gallery as this block of stone was lifted and placed high above the sanctuary.

fig2.06 interior view of cathedral during construction - Christchurch Diocese Archives. (1902). This interior view clearly shows the small tramway laid down the middle of the nave to move blocks of stone.

fig2.07 plan of cathedral as it was originally proposed by francis petre - Christchurch Diocese Archives. (1901). The plan of the Cathedral of the Blessed Sacrament as it was originally proposed by Francis Petre.

fig2.08 holy souls chapel, bishop grimes' final resting place - Christchurch Diocese Archives. (1993). Holy Souls Chapel.

fig2.09 interior view of the nave, showing the repetitive colonnades used throughout the building as an architectural feature - Christchurch Diocese Archives. (1993). Photo of nave.

fig2.10 celebrating mass post vatican ii and renovation works - Christchurch Diocese Archives. (1993). Celebration of Mass.

fig3.01 material breakdown of construction and demolition waste in new zealand - Authors Own

fig4.01 example of spolia at san procolo temple in verona - Luiz, J. (2016, September 16). Spolia San Procolo. Retrieved from Commons: https://commons.wikimedia.org/wiki/File:Spolia_-_San_Procolo_-_Verona_2016.jpg fig4.02 north campus of berlin humboldt university - CEMEX. (2015, December 7). North Campus of Berlin Humboldt University. Retrieved from CEMEX: https://www.cemex.com/-/cemex-pilot-project-in-berlin-showcasesspecialty-concrete-with-recycled-aggregates

fig4.03 the 4-storey humboldt university made from recycled concrete - CEMEX. (2015, December 7). The 4-story Humboldt University building. Retrieved from CEMEX: https://www.cemex.com/-/cemex-pilot-project-in-berlinshowcases-specialty-concrete-with-recycled-aggregates

fig4.04 interior view of ilford community market - Webb Yates Engineers. (2020). Ilford Community Market. Retrieved from Webb Yates Engineers: https://www.webbyates.com/projects/ilford-community-market/ fig4.05 ilford community market - Webb Yates Engineers. (2020). Ilford Community Market. Retrieved from Webb Yates Engineers: https://www.webbyates.com/projects/ilford-community-market/

fig4.06-4.08 exterior photos of im birch school, zurich's first recycled concrete building - Bonell, L. (2018). Im Birch School. Retrieved from Afasia Archzine: https://afasiaarchzine.com/2018/11/peter-markli-9/ 
fig4.09 exterior elevation photo of erimtan museum, showing the reused stones - Onur Yuncu Architects. (2020). Erimtan Archaeology and Arts Museum. Retrieved from Onur Yuncu Architects: https://www.onuryuncu.com/512011-erimtanarchaelogyartsmuseum

fig4.10 copper door entrance to erimtan museum - Onur Yuncu Architects. (2020). Erimtan Archaeology and Arts Museum. Retrieved from Onur Yuncu Architects: https://www.onuryuncu.com/51-2011erimtanarchaelogyartsmuseum

fig4.11 example of contemporary spolia, erimtan museum - Onur Yuncu Architects. (2020). Erimtan Archaeology and Arts Museum. Retrieved from Onur Yuncu Architects: https://www.onuryuncu.com/51-2011erimtanarchaelogyartsmuseum

fig5.01 extra volume on side elevation providing extra height inside - Pegenaute, P. (2013). Shrine of the Virgin of La Antigua by Otxotorena Arquitectos. Retrieved from Dezeen: https://www.dezeen.com/2013/03/14/shrine-of-thevirgin-of-la-antigua-by-otxotorena-arquitectos/

fig5.02 salvaged archways reused in the design - Pegenaute, P. (2013). Shrine of the Virgin of La Antigua by Otxotorena Arquitectos. Retrieved from Dezeen: https://www.dezeen.com/2013/03/14/shrine-of-the-virgin-of-laantigua-by-otxotorena-arquitectos/

fig5.03 exterior photo of the shrine of the virgin of la Antigua - Pegenaute, P. (2013). Shrine of the Virgin of La Antigua by Otxotorena Arquitectos. Retrieved from Dezeen: https://www.dezeen.com/2013/03/14/shrine-of-thevirgin-of-la-antigua-by-otxotorena-arquitectos/

fig5.04 corridor shot showing the old vs new in materiality - Pegenaute, P. (2013). Shrine of the Virgin of La Antigua by Otxotorena Arquitectos. Retrieved from Dezeen: https://www.dezeen.com/2013/03/14/shrine-of-thevirgin-of-la-antigua-by-otxotorena-arquitectos/

fig5.05 interior view of st moritz's nave showing how bright and light the space is - McCarragher, G. (2013). St Moritz Church by John Pawson. Retrieved from Dezeen: https://www.dezeen.com/2013/07/31/st-moritz-church-byjohn-pawson/

fig5.06 rounded arches along the side of the nave of st moritz - McCarragher, G. (2013). St Moritz Church by John Pawson. Retrieved from Dezeen: https://www.dezeen.com/2013/07/37/st-moritz-church-by-john-pawson/ fig5.07 st moritz minimal sanctuary to not distract the churchgoers - McCarragher, G. (2013). St Moritz Church by John Pawson. Retrieved from Dezeen: https://www.dezeen.com/2013/07/37/st-moritz-church-by-john-pawson/ fig5.08 st jean vianney's architectural focus on the liturgy via octagonal form - Trahan Architects. (1999). St Jean Vianney. Retrieved from Trahan Architects: https://trahanarchitects.com/work/st-jean-vianney/

fig5.09 entrance and baptismal font - Trahan Architects. (1999). St Jean Vianney. Retrieved from Trahan Architects: https://trahanarchitects.com/work/st-jean-vianney/

fig5.10 simplicity in the use of materials in the church - Trahan Architects. (1999). St Jean Vianney. Retrieved from Trahan Architects: https://trahanarchitects.com/work/st-jean-vianney/

fig6.01 catholic basilica and its surroundings pre-earthquakes - Christchurch Diocese Archives. (1993). Aerial Photo of Cathedral of the Blessed Sacrament.

fig6.02 aerial photo of new site - Christchurch Diocese. (2019). Bishop Paul Martin. Screengrab Retrieved from YouTube: https://www.youtube.com/watch?reload=9\&v=mEiVniCqEiw\&t=7s

fig 6.03-6.04 the new site is currently a car park as it has been empty since 2011 - Authors Own

fig6.05 map showing old vs new site - Adapted from: Google Earth

fig6.06 context site analysis showing amenities around the new site - Authors Own

fig6.07 site analysis showing what is happening around the new site - Authors Own

fig6.08 map showing points of views - Authors Own 
fig6.09-6.17 different views around the site - Authors Own

fig6.18 massing plan for the different proposed buildings on new site - Authors Own

fig7.01 site analysis for cathedral based off massing plan - Authors Own

fig7.02 copper dome of catholic basilica - Christchurch Diocese Archives. (2015, May 22). Cathedral - Internal May

2015.

fig7.03 limestone used throughout the cathedral after the earthquakes - Christchurch Diocese Archives. (2015,

May 22). Cathedral - Internal May 2015.

fig7.04 concrete rubble in the cathedral after earthquakes - Christchurch Diocese Archives. (2015, May 22).

Cathedral - Internal May 2015.

fig7.05 kauri wood roof framing exposed after earthquakes - Christchurch Diocese Archives. (2015, May 22).

Cathedral - Internal May 2015.

fig7.06 pressed zinc sheet ceiling in the nave left exposed after earthquakes - Christchurch Diocese Archives.

(2015, May 22). Cathedral - Internal May 2015.

fig7.07 columns still standing after surviving earthquakes - Christchurch Diocese Archives. (2015, May 22).

Cathedral - Internal May 2015.

fig8.01 grounded expressive painting - Authors Own

fig8.02 intimacy expressive painting - Authors Own

fig8.03 transcendence expressive painting - Authors Own

fig8.04 bridge expressive painting - Authors Own

fig8.05 adjacency matrix of spaces in cathedral - Authors Own

fig8.06 bubble diagram of spaces in cathedral - Authors Own

fig8.07 diagram showing analysis of relationship of spaces - Authors Own

fig8.08 diagram showing relationship of spaces and types of interaction within - Authors Own

fig8.09 sketches of different possible spatial configurations - Authors Own

fig8.10 geometric elevation sketch - Authors Own

fig8.11 sketch of confessional and the idea of privacy and forgiveness - Authors Own

fig8.12 sketch of a baptistery and font - Authors Own

fig8.13 sketch of partial elevation showing a glass dome - Authors Own

fig8.14 sketch of spire adopting an organic form and towering over the nave behind it - Authors Own

fig8.15 sketch showing the different levels in the sanctuary, emphasising the idea of hierarchy within the building - Authors Own

fig8.16 concept 1 sketch - Authors Own

fig8.17 concept 2 sketch - Authors Own

fig8.18 concept 3 sketch - Authors Own

fig8.19 concept 4 sketch - Authors Own

fig9.01 first stage of preliminary design - Authors Own

fig9.02 second stage of preliminary design - Authors Own

fig9.03 small changes made to develop the preliminary design - Authors Own

fig9.04 sketches of different ideas for confessional divider reusing the kauri wood roof framing - Authors Own fig9.05 perspective drawing of confessional divider providing privacy - Authors Own

fig9.06 design for the sanctuary crucifix, stacking different planks of wood from old roof framing to create a crucifix that is unique and holds history - Authors Own 
fig9.07 perspective drawing of crucifix hanging from ceiling in sanctuary - Authors Own

fig9.08-9.09 perspective drawings of narthex with timber slats on the ceiling as an architectural feature to make the space feel inviting - Authors Own

fig9.10 copper feature wall in the memorial chapel - Authors Own

fig9.11 copper feature wall in the side chapel providing a nice backdrop to the small altar - Authors Own

fig9.12 sketches of different ideas for layout of stations of the cross garden - Authors Own

fig9.13 perspective sketch of stations of the cross garden - Authors Own

fig10.01 site plan with all proposed buildings on site - Authors Own

fig10.02 exterior view of the cathedral, offering a preview of its architectural form and heavy focus on the reuse of materials while people interact outside with the site - Authors Own

fig10.03 cathedral site plan showing the cathedral itself as well as the stations of the cross garden at the back and a small plaza at the front, aiming to bring people onto the site and interacting with these public spaces -

Authors Own

fig10.04 ground floor plan - Authors Own

fig10.05 choir level floor plan - Authors Own

fig10.06 view from the west side aisle under the upper gallery - Authors Own

fig10.07 choir area overlooking the nave with the large cross opening providing a background and bringing light into the space - Authors Own

fig10.08 confessional room. reused kauri wood has been used to create confessional divider between priest and penitent - Authors Own

fig10.09 baptistery and baptismal font made from recycled concrete - Authors Own

fig10.10 view of back of the nave from the side aisles, showing the simplicity of the design and materiality directing the focus not on decorations and distractions but on the liturgy instead - Authors Own

fig10.11 the nave at night void of occupants, capturing the quietness and sacredness of the space - Authors Own fig10.12 the sanctuary during mass occupied by its intended users and demonstrating the hierarchal separation between the clergy and the lay through the raised level and the stairs - Authors Own

fig10.13 view of the nave from the sanctuary - Authors Own

fig10.14 view from upper gallery with white pressed zinc ceiling and the crucifix in the background. void of occupants, this render focuses on the materiality, particularly the heavy reuse of stone and concrete throughout the building emphasising the focus on material reuse to bring history into the building - Authors Own

fig10.15 side chapel, providing a space for smaller liturgies or private prayer with a copper feature wall as an architectural element and backdrop to the small altar - Authors Own

fig10.16 memorial chapel, where bishop grimes will be buried. feature wall made from copper panels of the old dome providing the space and bishop grimes a memorable piece of the old cathedral he built and served in. the list of benefactors of the old cathedral also hangs over on the wall - Authors Own

fig10.17 narthex and entrance of the cathedral, reused wood is used as timber slats on the ceiling to bring more colour and make the space more modern and inviting - Authors Own

fig10.18 stations of the cross garden, reusing the original stations of the cross from the old cathedral by artist Ilew summers and fixing them onto limestone blocks - Authors Own

fig10.19 stations of the cross garden, using ionic columns as markers/pillars next to llew summer's original stations of the cross - Authors Own

fig10.20 south-east exterior view of the cathedral showing the heavy use of stone in the design and showing the sloping architectural form - Authors Own 
fig10.21 the sanctuary is an expansive and sacred space dedicated to the bishops and priests and the celebration of the liturgy - Authors Own

fig10.22 west elevation - Authors Own

fig10.23 south elevation - Authors Own

fig10.24 east elevation - Authors Own

fig10.25 north elevation - Authors Own

fig10.26 section a-a' long section of cathedral - Authors Own

fig10.27 section b-b' short section of the cathedral - Authors Own

fig10.28 exterior shot of the west side of the cathedral showing the sheer scale and height of the building Authors Own 
